UNIVERSIDADE DE BRASÍLIA

INSTITUO DE PSICOLOGIA

Programa de Pós-Graduação em Processos de Desenvolvimento humano e Saúde

O PEDAGOGO-ORIENTADOR EDUCACIONAL NO ACOLHIMENTO E ACOMPANHAMENTO DE ADOLESCENTES EM MEDIDA SOCIOEDUCATIVA

IZETE SANTOS DO NASCIMENTO

BRASÍLIA-DF 


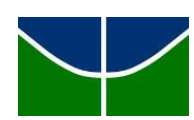

UNIVERSIDADE DE BRASÍLIA

INSTITUO DE PSICOLOGIA

Programa de Pós-Graduação em Processos de Desenvolvimento Humano e Saúde

Área de Concentração: Desenvolvimento humano e Educação

Linha de Pesquisa: Processos Educativos e Psicologia Escolar

\title{
O PEDAGOGO-ORIENTADOR EDUCACIONAL NO ACOLHIMENTO E ACOMPANHAMENTO DE ADOLESCENTES EM MEDIDA SOCIOEDUCATIVA
}

\author{
IZETE SANTOS DO NASCIMENTO
}

Dissertação apresentada ao Instituto de Psicologia da Universidade de Brasília, como parte dos requisitos para obtenção do título de Mestre em Processos de Desenvolvimento Humano e Saúde, área de concentração Desenvolvimento Humano e Educação.

Orientadora: Prof.. Dr. ${ }^{a}$ LÚCia Helena CAvasin Zabotto Pulino 
Ficha catalográfica elaborada automaticamente, com os dados fornecidos pelo (a) autor (a)

Santos do Nascimento, Izete

SSA237 O Pedagogo-Orientador Educacional no Acolhimento

p e Acompanhamento de Adolescentes em Medida Socioeducativa / Izete Santos do Nascimento; orientador Lúcia Helena Cavasin Zabotto Pulino. -- Brasília, 2017.

$145 \mathrm{p}$.

Dissertação (Mestrado - Mestrado em Processos de Desenvolvimento Humano e Saúde) -- Universidade de Brasília, 2017.

1. Desenvolvimento Humano. 2. Adolescência. 3. Orientador Educacional. 4.

Socieducação. 5. Histórico cultural. I. Pulino, Lúcia Helena Cavasin Zabotto, orient. II. Título. 


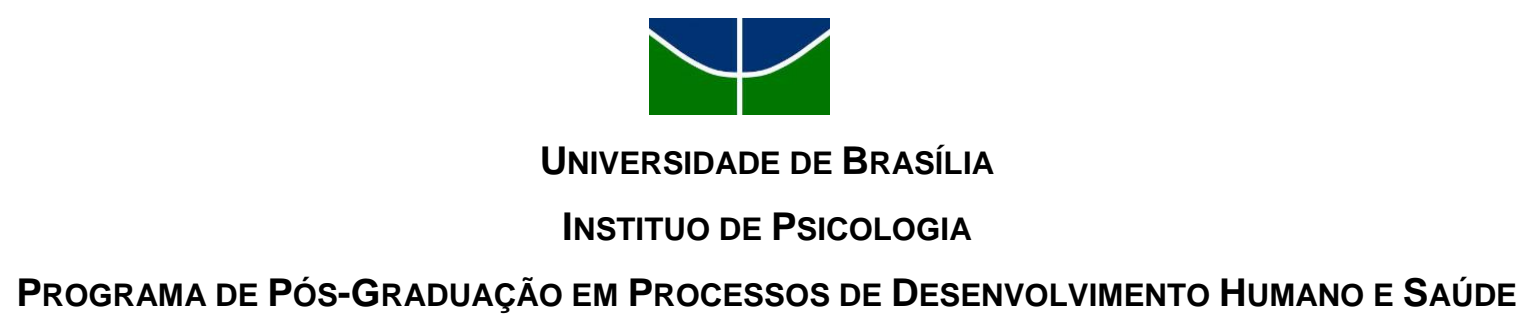

Área de Concentração: Desenvolvimento Humano e Educação

LiNHa de Pesquisa: Processos Educativos e Psicologia Escolar

A Dissertação de Mestrado "O Pedagogo-Orientador Educacional no Acolhimento e Acompanhamento de Adolescentes em Medida Socioeducativa", de autoria de Izete Santos do Nascimento, foi aprovada pela seguinte Banca Examinadora

Prof. ${ }^{\text {a }}$ Dr. ․ㅡ Lúcia Helena Cavasin Zabotto Pulino - Presidente PGPDS/PED/IP/UnB

Prof. a Dr. a Sílvia Renata Magalhães Lordello Borba Santos - Membro Titular PPGPSICC/PCLI/IP/UnB

Prof. ${ }^{\text {a Dr. }}{ }^{\text {a }}$ Maristela Rossato - Membro Titular PGPDS/PED/IP/UnB

Prof. ${ }^{a}$ Diva Maria Morais Albuquerque Maciel - Membro Suplente PGPDS/PED/IP/UnB 
No entanto, as coisas são muito simples. A moral, qualquer que seja o sentido em que a entendemos, ou qualquer que seja sua doutrina de referência, é, principalmente, o respeito pelo outro, ao que devemos acrescentar benevolência, a generosidade e até mesmo, vamos dizer a palavra, a bondade. (...), mas também podemos dizer as coisas simplesmente: comporto-me moralmente com meus vizinhos, parentes e próximos quando os respeito e os ajudo, quando reconheço seus direitos imprescritíveis de pensar diferente de mim, e mesmo nessa hipótese faço o que posso para tornar-lhes a vida mais suave e fácil. (Ferry, Luc, 2012). 


\section{Gratidão}

A Deus: "Porque nele vivemos, e nos movemos, e existimos" (Atos 17.28a).

À minha família pelo apoio e incentivo.

Ás minhas amigas Denise Soares e Marisete Guabiraba pela parceria, amizade e consideração.

À minha orientadora, Prof. ${ }^{a}$ Dr. ${ }^{a}$ Lúcia Helena Cavasin Zabotto Pulino pelo ser humano incrível que é. Por sua bondade, amizade e respeito na academia e na vida.

Aos colegas de Mestrado pelas aprendizagens e conhecimentos compartilhados.

Aos colegas Pedagogos-Orientadores Educacionais da Secretaria de Estado de Educação do Distrito Federal pela colaboração na pesquisa.

Aos estudantes adolescentes que trouxeram suas impressões juvenis a esse trabalho, e, acima de tudo, por me permitir ampliar o olhar para além do que meus olhos conseguem enxergar na vida e no ambiente educativo.

Às professoras do Programa de Pós-Graduação em Processos de Desenvolvimento Humano e Saúde - Lúcia Helena Cavasin Zabotto Pulino, Silviane Bonaccorci Barbato, Regina Lúcia Sucupira Pedroza, Claisy Maria Marinho-Araújo, Jane Farias Chagas-Ferreira, Maristela Rossato, Fabrícia Borges, Maria Cláudia Santos Lopes de Oliveira.

Aos colegas do Laboratório Ágora, pelas discussões e crescimento acadêmico, especialmente, às professoras Lúcia Helena e Regina Pedroza.

Aos colegas do Laboratório de Microgênese das Interações Sociais (Labmis).

Às professoras Sílvia Lordello, Maristela Rossato e Diva Maciel, Membros da Banca Examinadora, que aceitaram gentilmente o convite para construirmos o fazer acadêmico na Universidade e promover reflexões a partir da minha dissertação.

Aos colegas da Secretaria do PED e funcionários da UnB pela prestatividade no atendimento às nossas necessidades enquanto mestrandos. 
Esta pesquisa contou com o seguinte apoio institucional:

Secretaria de Estado de Educação do Distrito Federal

Concessão de Afastamento Remunerado para Estudos

(DODF: 05/03/2015, Processo 080.012165/2014)

Comitê de Ética em Pesquisa do Instituto de Ciências Humanas (UnB) 


\section{RESUMO}

Este trabalho baseou-se no estudo sobre o papel do Pedagogo-Orientador Educacional no acolhimento e acompanhamento de estudantes adolescentes em cumprimento de medida socioeducativa em escolas da rede pública de ensino no Distrito Federal. Teve-se como Objetivo geral: Analisar a atuação do Pedagogo-Orientador Educacional junto aos estudantes em cumprimento de medida socioeducativa. Trabalhou-se no contexto da Rede Pública de Ensino no Distrito Federal, na modalidade Educação de Jovens e Adultos e Ensino Médio. Exploraram-se os temas: Contextualização do Serviço de Orientação Educacional na educação brasileira e Desenvolvimento Humano Adolescente na perspectiva da Psicologia Histórico-Cultural de Vigotski, que compreende o sujeito constituído por meio de relações mediadas culturalmente. A pesquisa foi inspirada na Epistemologia Qualitativa, de natureza construtivo-interpretativa. Os participantes da pesquisa foram 4 Pedagogos-Orientadores Educacionais oriundos de 3 escolas públicas e 14 estudantes adolescentes de apenas 1 das instituições de ensino, envolvendo adolescentes que cumpriram medida socioeducativa e outros fora dessa condição. Para a construção de informações utilizou-se um Fórum de Debates com os participantes adultos, com as seguintes questões de pesquisa: O que é ser pedagogo-Orientador Educacional na Rede Pública de Ensino do Distrito Federal? Qual a sua compreensão sobre Socioeducação? Que tipo de conhecimento teóricolprático você considera importante para contribuir com seu trabalho junto aos jovens no contexto da Socioeducação? Como o Pedagogo-Orientador Educacional e a respectiva instituição de ensino pesquisada compreendem o papel da escola na rede Socioeducativa? De que maneira é feito o acolhimento e acompanhamento do estudante adolescente que esteja em cumprimento de medida de Liberdade Assistida (LA)? Quais as contribuições da instituição de ensino na inclusão de estudantes em medida de LA? Com os adolescentes realizou-se uma Oficina de Jogos Teatrais na metodologia do Teatro do Oprimido do teatrólogo Augusto Boal. As análises e discussões foram feitas a partir da construção de indicadores, na perspectiva de González Rey e foram as seguintes: 1) posição de reflexão e crítica ao trabalho do Pedagogo-OE no ambiente escolar aparecem inseparáveis; 2) empatia e caráter de orientação estudantil e da família; 3) O que cada um é e o que não é na sua função na escola; 4) posição pessoal frente aos desafios no ambiente escolar; 5) reconhecimento da incompletude das políticas públicas na rede socioeducativa; 6) Socioeducação, teoria e prática no contexto da escola; 7) Qual o papel da escola na vida do adolescente autor de 
ato infracional; 8) Escola como espaço de acolhimento; 9)a inclusão como um direito de todos no cenário da escola; 10) O que mais preocupa e interessa aos jovens: diferentes olhares. As considerações finais mostraram que não há uma padronização entre os Pedagogos-OE no acolhimento e acompanhamento de estudantes em LA; apontou a carência de literatura sobre o entendimento da prática da Socioeducação pelo profissional, de uma forma geral; apontou também a necessidade de formação em Socioeducação para Orientadores Educacionais e professores. Foram indicadas proposições para discussão nos espaços escolares de temas como: a compreensão de que a adolescência é um período de desenvolvimento construído; o entendimento da criança e do adolescente como sujeitos de direitos; a necessidade da oferta da educação em e para os direitos humanos. Indicou-se, também, a necessidade urgente da produção de literatura e pesquisas que contribua para o trabalho dos profissionais que atuam na rede socioeducativa escolar.

Palavras-Chave: desenvolvimento humano; adolescência; orientador educacional; socioeducação, histórico-cultural

*O termo Pedagogo-Orientador Educacional é utilizado no Distrito Federal para denominar o profissional do Serviço de Orientação Educacional e foi instituído pela Lei no 5.515 , de 13 de maio de 2013, que reestruturou a Carreira do Magistério Público do DF. 


\section{ABSTRACT}

This work was based on the study of the role of the Pedagogist-Educational Advisor during welcoming and assistance of adolescent students under socio-educational measure in public schools of Distrito Federal. The objective of this study was to analyze the professional practice of the Pedagogist-Educational Advisors $(P-E A)^{*}$ with the students under socioeducational measure. The research was conducted in the context of the Public Education system of Distrito Federal, specifically in two modalities: Youth and Adult Education and Secondary Education. The following themes were explored: Contextualization of Educational Guidance Services in Brazilian Education and Adolescent Human Development on the perspective of Historical-cultural Psychology proposed by Vigotski - which understands the constitution of a subject through culturally mediated relations. The study was inspired in the Qualitative Epistemology of constructive-interpretative nature. The participants of the research were: 4 P-EA from 3 public schools and 14 adolescent students from only 1 of the educational institutions, comprising adolescents who complied with socio-educational measure and others that were not on this condition. The construction of information process was conducted through a Debate Forum with the adult participants, composed of the following research questions: What is it like to be a Pedagogist-Educational Advisor in the Public Education system of Distrito Federal? What's your understanding of Socio-education? What kind of theoretical/practical knowledge you consider important to contribute for your practice with the adolescents in Socio-educational situation? How do the P-EA and the educational institution understand the role of the school in the Socio-educational system? How is the welcoming and assistance of adolescent students complying with open socioeducational measure (LA) conducted? What are the contributions of the Educational Institution in the inclusion process of students complying with open socio-educational measure (LA)? With the adolescent participants, a Workshop of Theatre Games was carried out. The workshop was developed according to the methodology of the Theatre of the Oppressed - which describes theatrical forms elaborated by the Brazilian theatre practitioner Augusto Boal. The analysis and discussion were guided by the construction of indicators on the perspective of González Rey. These indicators were: 1) reflexive thinking and critical view toward the practice of the P-EA in the educational context appear as inseparable; 2) empathy and nature of student and family assistance; 3 ) what each subject is and isn't according to the their function in school; 4) personal stance toward the challenges of school environment; 5) recognition of the incompleteness of public policies in the Socio-educational system; 6) Socio-education, theory and practice in school context; 7) the role of school in the life of the adolescent who committed infraction; 8) school as a welcoming setting; 9) 
inclusion as everyone's right in the school scenario; 10) concerns and interests of youth: different perceptions. The final considerations showed: that there is no standardization in the process of welcoming and assistance of the students in LA among the P-EA; a lack of literature on understanding the practice of Socio-education by the professional in a general way; as well as the need for training in Socio-education for both Educational Advisors and teachers. The conclusion indicates propositions for discussion in school spaces of relevant topics, such as: the understanding of adolescence as a culturally constructed stage of development; the understanding of children and adolescents as subjects of rights; the necessity of an Education in and for Human Rights. It was also indicated the urgent need for the construction of literature and research that can contribute to the work of professionals in the school socio-educational system.

Keywords: human development; adolescence; educational advisor; socio-education; historical-cultural.

* The term Pedagogist-Educacional Advisors is used in the Distrito Federal to designate the professional of the Educational Guidance Service and was instituted by Lei $n$. 5.515, dated May 13, 2013, which restructured the Career of the Public Magisterium of the DF. 


\section{SUMÁRIO}

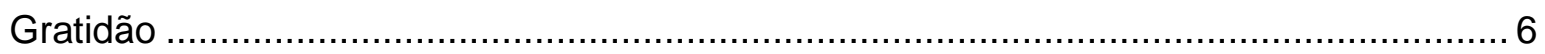

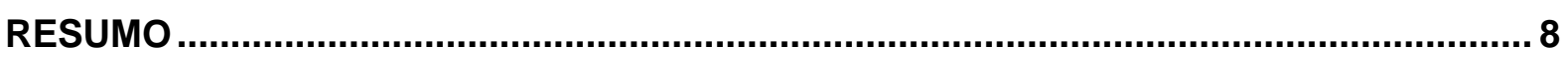

ABSTRACT ..........................................................................Erro! Indicador não definido.

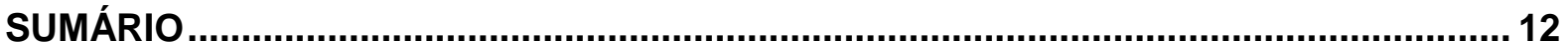

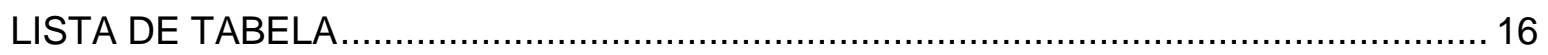

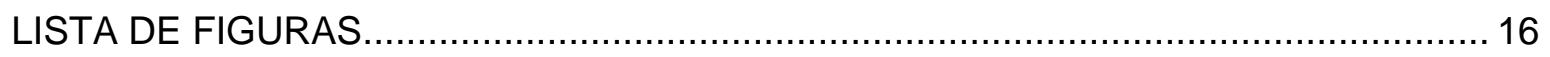

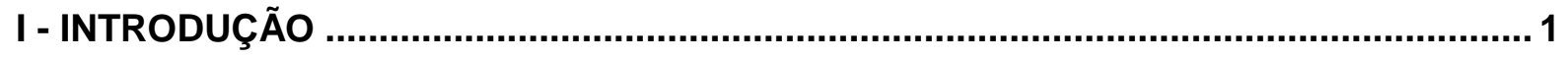

II - FUNDAMENTAÇÃO TÉORICA .................................................................... 4

Contextualização do Serviço de Orientação Educacional na História da Educação

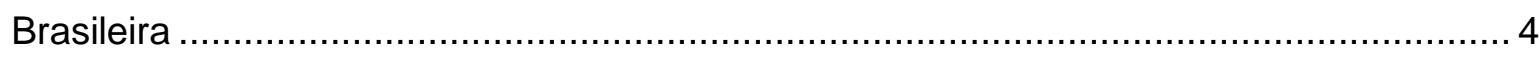

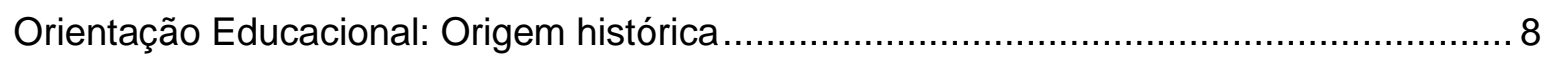

As especificidades do Serviço de Orientação Educacional - O que é? Onde? Para quem?

Por quem? Como? Por que e para que? .............................................................. 12

O Orientador Educacional na Rede Pública de Ensino do DF ................................... 13

O Profissional de Orientação Educacional.......................................................... 14

Atribuições do Serviço de Orientação Educacional.................................................. 15

As influências Filosóficas ao trabalho do OE ...................................................... 17

III - PSICOLOGIA DO DESENVOLVIMENTO ............................................................. 20

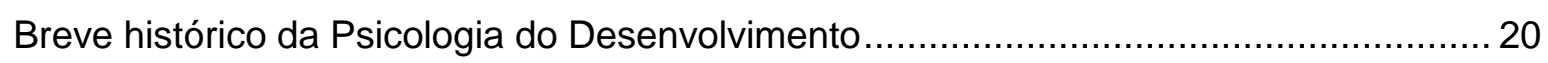

O Desenvolvimento Humano na Perspectiva Histórica .............................................. 24

O caráter Histórico-cultural do Desenvolvimento Humano em Karl Marx e Vigotski......... 25

Métodos de pesquisa em Psicologia do Desenvolvimento......................................... 31

A Psicologia do Desenvolvimento e a Educação ........................................................ 33

Desenvolvimento Humano e Adolescência............................................................ 33 


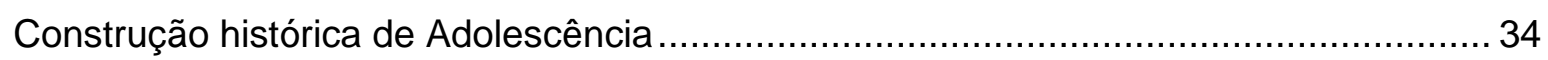

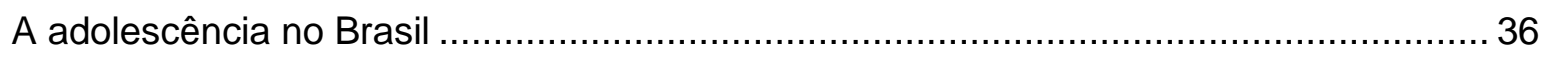

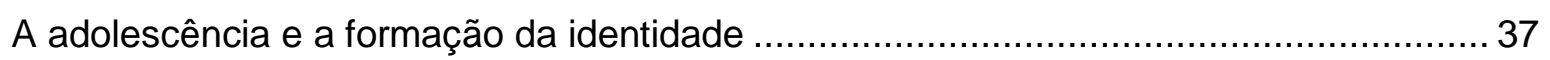

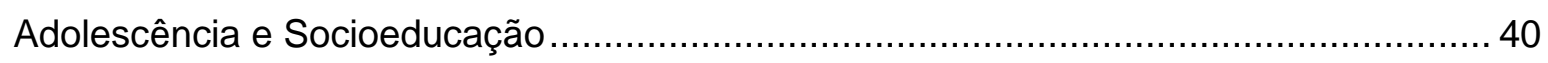

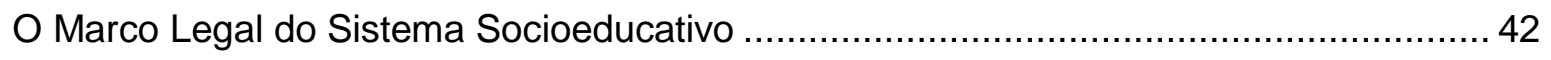

O Sistema de Medidas Socioeducativas, a adolescência e a violência na escola ........... 43

A Socioeducação e a História da Educação no Brasil ............................................... 46

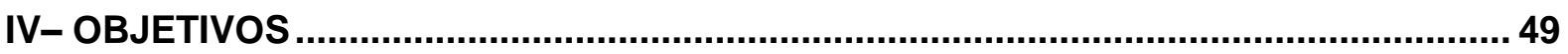

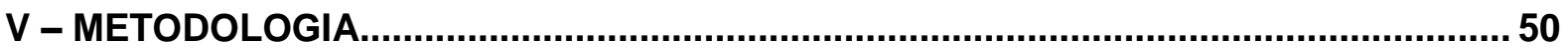

A Epistemologia da Pesquisa Qualitativa em González Rey ........................................ 50

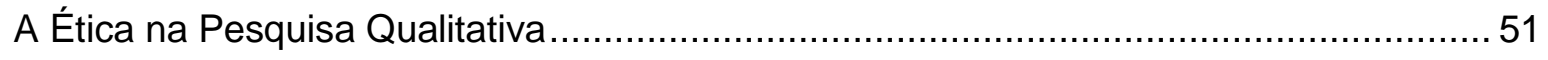

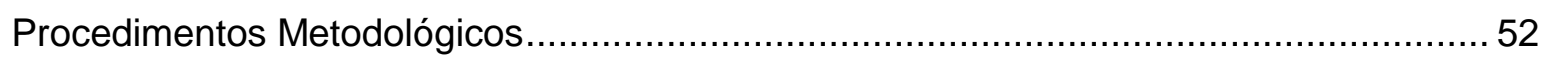

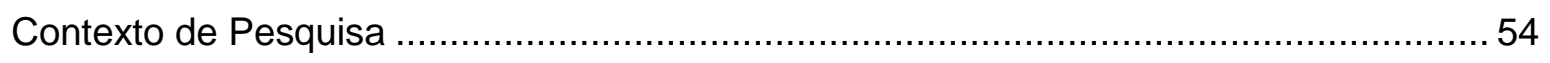

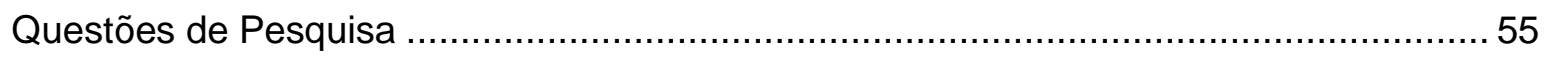

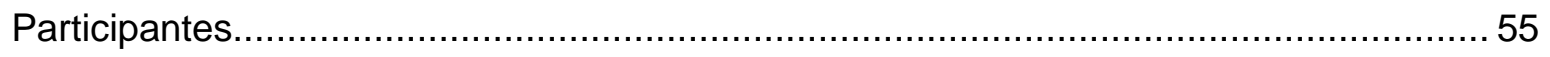

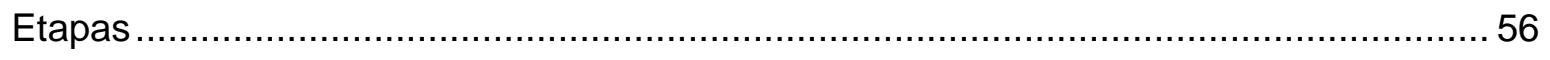

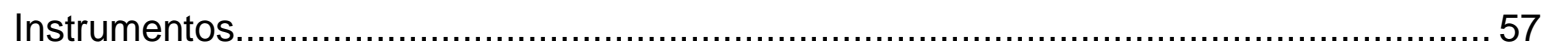

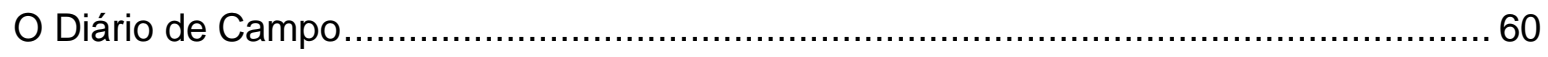

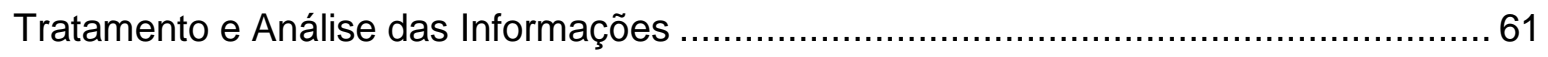

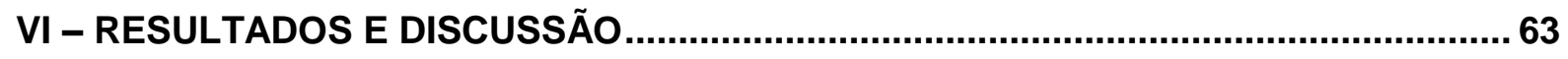

Questão de pesquisa 01: O que é ser Pedagogo-OE na Rede Pública de Ensino do

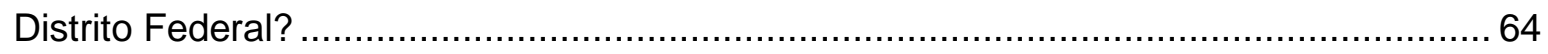

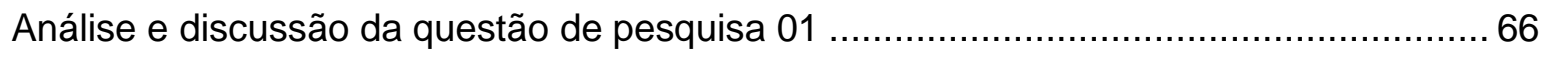

Questão de pesquisa 02: Qual a sua compreensão sobre a Socioeducação?................. 69

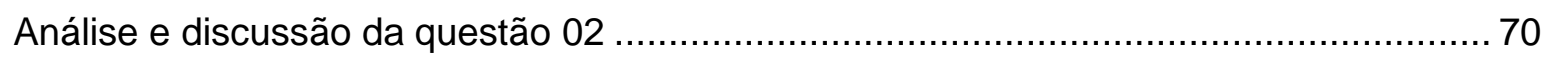


Questão de pesquisa 03: Que tipo de conhecimento teórico/prático você considera importante para contribuir com seu trabalho junto aos jovens no contexto da Socioeducação?

Questão de pesquisa 04: Qual a sua percepção da compreensão que a escola onde atua tem da Socioeducação? Como o Pedagogo-OE e a respectiva instituição de ensino pesquisada compreendem o papel da escola na rede socioeducativa?.... 76

Análise e discussão da questão 04 77

Questão de pesquisa 05: De que maneira é feito o acolhimento e acompanhamento do estudante adolescente que esteja em cumprimento de medida de Liberdade Assistida? 79 Análise e discussão da questão 05 79

Questão de pesquisa 06: Quais as contribuições da instituição de ensino na inclusão de estudantes em medida de LA?. 82

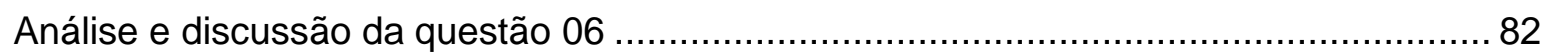

A Oficina com os estudantes adolescentes participantes da pesquisa ........................... 84

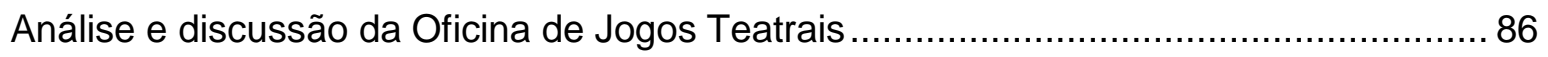

Análise dos espaços de fala entre os Pedagogos-Orientadores Educacionais e os Estudantes Adolescentes no Ambiente Escolar. 88

VII - CONSIDERAÇÕES FINAIS. 91

REFERÊNCIAS BIBLIOGRÁFICAS. 95

ANEXOS 102

Anexo 1 103

ACEITE INSTITUCIONAL 103

Anexo 2. 104

ROTEIRO DE CONSTRUÇÃO DE INFORMAÇÕES COM PEDAGOGOS-

ORIENTADORES EDUCACIONAIS ................................................................. $1 \mathrm{n} 4$

Anexo 3 105 105 


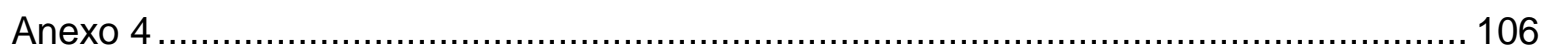

TERMO DE AUTORIZAÇÃO PARA UTILIZAÇÃO DE IMAGEM E SOM DE VOZ ......... 106

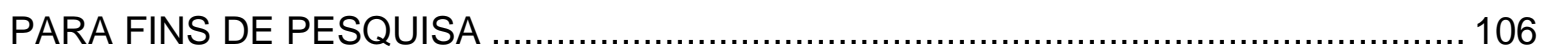

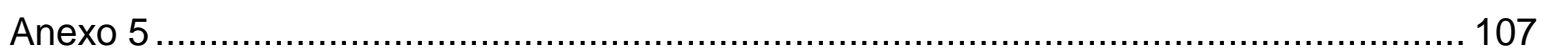

TERMO DE RESPONSABILIDADE PELO USO DE INFORMAÇÕES E CÓPIAS DE DOCUMENTOS PARA FINS DE PESQUISA. 
Tabela 01 - Caracterização dos Pedagogos-Orientadores Educacionais.

\section{LISTA DE FIGURAS}

Figura 1 - A representação da Árvore do Oprimido.

Figura 2 - A operacionalização do Teatro do Oprimido. 


\section{I - INTRODUÇÃO}

Este trabalho consistiu num estudo sobre no estudo sobre o papel do PedagogoOrientador Educacional no acolhimento e acompanhamento de estudantes adolescentes em cumprimento de medida socioeducativa em escolas da rede pública de ensino no Distrito Federal. Teve-se como Objetivo geral: Analisar a atuação do Pedagogo-Orientador Educacional junto aos estudantes em cumprimento de medida socioeducativa. Dessa forma, a pesquisa contextualiza a Orientação Educacional na história da educação brasileira, assim como a Psicologia do Desenvolvimento, com ênfase na adolescência, à luz da perspectiva histórico-cultural de Vigotski

Os dados do Censo Escolar da Secretaria de Estado de Educação do Distrito Federal (DF) referentes ao ano de 2013 divulgados em setembro de 2014 mostram que, embora o número de estudantes matriculados nas 664 Unidades de Ensino, espalhadas por 14 Regionais, tenha sofrido uma queda de 2,4\% em relação ao ano de 2012, em 2013 teve um acréscimo de 5,4\%. São cerca de 470 mil estudantes, da Educação Infantil, passando pelo Ensino Fundamental, Ensino Médio, Educação de Jovens e Adultos e ainda o Ensino Especial.

Dos profissionais que trabalham com o público infanto-juvenil e com adultos, 22.000 (vinte e dois mil) são Docentes, sem contar Auxiliares de Educação, Monitores, terceirizados e Agentes de Portaria. Os Pedagogos-Orientadores Educacionais somam um total de 850 (SEEDF, 2014). Pode-se pensar que há um Orientador Educacional para cada escola, no entanto, os mesmos estão distribuídos nos três turnos: manhã, tarde e noite, inclusive na zona rural, com carga horária (20 e ou 40 h semanais), em escolas distintas. 0 que significa dizer, que há turnos desprovidos desse profissional.

São múltiplas e diversificadas as atribuições do Pedagogo-Orientador Educacional no ambiente escolar. O exercício do seu trabalho exige domínio do conhecimento suficiente para tratar questões ligadas à expressão sexual, saúde preventiva, profissionalização, meio ambiente, ética e cidadania, cultura de paz, prevenção ao uso de drogas, entre outros, com o objetivo de auxiliar na promoção do desenvolvimento integral do educando, em conjunto com os demais atores no ambiente escolar: estudantes, educadores, pais ou responsáveis e comunidade adjacente. Nesse conjunto de atividades está o acompanhamento de alunos em cumprimento de Medida Socioeducativa (MSE), especificamente a Liberdade Assistida (LA).

Após os trâmites legais que envolvem o processo de apreensão do adolescente que comete ato infracional, de acordo com o artigo no 112 do Estatuto da Criança e do 
Adolescente (ECA), o mesmo pode ter que cumprir MSE em meio aberto, com advertência, obrigação de reparar o dano, prestar serviços comunitários ou liberdade assistida. Uma das obrigações atribuídas ao apenado em cumprimento de LA está a matrícula e permanência em Unidade Educacional de sua escolha ou por indicação da Coordenação Regional de Ensino

Na grande maioria das escolas públicas do DF o Pedagogo-OE lotado na Unidade de Ensino na qual o adolescente está matriculado, é o profissional de educação responsável, informalmente, pois não existe uma legislação que contenha essa obrigatoriedade, tanto pelo acolhimento quanto pelo acompanhamento do estudante no ambiente escolar, assim como coletar bimestralmente os dados de desempenho acadêmico, em conjunto com o Corpo Docente e encaminhar à Unidade de Atendimento em Meio Aberto (UAMA), resguardando o sigilo das informações. Observa-se, no entanto, que a convivência do estudante em cumprimento de medida socioeducativa no ambiente escolar nem sempre é amigável ou bem-vinda. Isso pode comprometer seu desenvolvimento acadêmico, fato que é alvo de preocupações por parte do profissional de Orientação Educacional que, ao preencher os relatórios avaliativos precisa informar tal insucesso acadêmico ao órgão competente.

Outro fator que destacamos no trabalho do Pedagogo-OE, especificamente com relação ao acompanhamento do estudante na instituição de ensino, diz respeito à distanciamento nas comunicações e informações na prática, existente entre a escola e os órgãos de execução e acompanhamento das medidas socioeducativas aplicadas ao adolescente.

Apesar da responsabilidade de acompanhar o desempenho acadêmico dos estudantes e enviá-los ao órgão executor, através da UAMA, a partir do momento da emissão das informações, não se sabe, de fato, qual a real situação do acautelado, como está sua vida, em relação ao cumprimento da medida. O sentimento de via de mão única é uma sensação muito presente na atuação do Pedagogo-Orientador Educacional, ou seja, não há uma fluidez no compartilhamento das ações.

O Perfil e percepção social dos adolescentes em medida socioeducativa no Distrito Federal foi publicado pela Companhia de Planejamento do Distrito Federal (CODEPLAN, 2013). Nele são apontados dados como local de residência, naturalidade, sexo, etnia, religião, composição do núcleo familiar, nupcidade e fecundidade, escolarização, reincidência, atos infracionais, perfil dos gastos, renda, além de experiência familiar e percepção sobre a medida socioeducativa (tempo e vínculo, acompanhamento do processo, profissionalização, esporte e cultura, violência e segurança) entre outras percepções. O estudo mostra um panorama do papel do adolescente na sociedade de acordo com a visão 
protagonista da sua situação no cumprimento das medidas socioeducativas. Perfil esse que perpassa por vários segmentos sociais e, sem dúvida, a escola.

Atualmente, percebe-se ausência de literatura acadêmica que aborde a atuação do Orientador Educacional no que concerne à Socioeducação no Brasil. Nesse sentido, a pesquisa busca contribuir para as discussões sobre a temática da socioeducação no contexto da escola pública e a tramas que envolvem as interações nesse ambiente, sob o viés da perspectiva histórico-cultural, de caráter construtivo e interpretativo no cenário socioeducacional no qual o Pedagogo-OE desempenha suas funções. 


\section{II - FUNDAMENTAÇÃO TÉORICA}

Tudo é possível, concreto, material nesse mundo, e, ao mesmo tempo, tudo nele está marcado por um pensamento e por uma atividade necessária.

(Mikhail Bakhtin, O romance de educação na história do realismo).

Neste capítulo faremos uma contextualização sobre a educação brasileira (história, organização, mudanças, políticas, possibilidades e desafios). Outrossim, trataremos da Orientação Educacional no Brasil e no mundo (historicidade, princípios, métodos, fundamentação legal, atribuições, entre outros).

\section{Contextualização do Serviço de Orientação Educacional na História da Educação Brasileira}

A história da educação brasileira tem seu início à época do Brasil-Colônia (1549), com a vinda dos jesuítas, os quais se instalaram no estado da Bahia e criaram ali o Colégio dos meninos de Jesus, além de escolas primárias e secundárias. Em 1827, a denominada Educação brasileira do Primeiro Reino, trouxe consigo a criação da primeira lei orgânica do ensino, período no qual foram criados os cursos jurídicos em São Paulo e Olinda.

Outros registros dessa trajetória mostram, o Segundo Reinado (1837-1859) com o curso normal (Bahia, Pernambuco, Paraíba, Rio Grande de Sul, entre outros), e a oficialização do curso secundário. O Regime Republicano, envidou as reformas nos cursos secundários e superiores (1911), a criação do Conselho Superior de Ensino, cursos preparatórios e criação de universidades, como a do Rio de Janeiro (1920). Novas reformas aconteceram em 1931 (Francisco de Campos), 1942 (Lei Capanema).

Ao longo da história do Brasil, as exigências provocadas pelo desenvolvimento e expansão da indústria, atrelado ao ganho de capital econômico, às novas formas de produção, avanço tecnológico e humano, como a necessidade de globalização em todas as esferas da sociedade - (governamental, social e econômica), exerceram profunda influência na educação brasileira e mundial. Nesse sentido, a escola é vista, cada vez mais, como espaço de interação (troca social, cultural, tecnológica, científica e organização 
pedagógica), de autonomia responsável, de protagonismo pessoal e de desenvolvimento de saberes (direito universal), além de construção coletiva e solidária, sem os quais a sobrevivência nesse 'novo mundo' torna-se comprometida.

A universalização da educação, preconizada pela Conferência Mundial sobre Educação para Todos, ocorrida no início dos anos 90 em Jomtien, na Tailândia, promovida pela Organização das Nações Unidas para a Educação, Ciência e Cultura (Unesco), estabeleceu, entre outras coisas, priorizar a educação nos países de Terceiro Mundo, principalmente o Ensino Fundamental. Em 1993, o Brasil instituiu a Plano Decenal de Educação para Todos. Na verdade, cada governo brasileiro, tem, de alguma forma, postulado a expansão da educação como direito de todos.

O estabelecimento de uma educação que alcance a maior parte dos brasileiros nem sempre foi assim. As primeiras grandes mudanças na educação, que antes era privilégio dos filhos da burguesia, os quais mantinham o domínio econômico e a cultural, estavam destinados a poucos integrantes da população brasileira, posteriormente aos indígenas (catequização portuguesa), restando aos negros o trabalho escravagista.

Com o advento da Revolução Industrial ocorrida no século XVIII, que causou grande impacto na educação escolar e em outros setores da sociedade brasileira, e o imperativo de qualificação da mão de obra e o interesse político e econômico sempre presente tanto de governos quanto da classe empresarial, o ensino começou a exigir novos arranjos, o que obrigou à instrução primária a um maior número de trabalhadores empregados, sem o qual, a produção e avanços do país ficariam comprometidos, o que ocasionou a expulsão dos jesuítas do pais (1759) e a estreia do ensino público no Brasil.

Ainda assim, boa parte da educação brasileira era realizada em Portugal, como os cursos superiores, ficando, nesse sentido, inacessível às classes menos favorecidas. Somente em 1808 é que o ensino superior veio a ser implementado no Brasil. Em 1824, o Brasil construía sua primeira Constituição, a qual incluía, no seu artigo 250 o sistema nacional de educação com escolas de nível primário, ginasial e universitário espalhadas pelo país, reservada, entretanto às classes mais abastadas, "A educação de classes populares era considerada supérflua e desnecessária", afirma Porto (2009, p. 27) Contudo, mulheres e homens tinham instituições distintas para se educar, ou seja, eram separadas por gênero, isso porque às mulheres estava reservado, além das atividades escolares, a aprendizagem de tarefas domésticas, tais como costurar e bordar.

Após a primeira República, instituída em 1889 e a influência positivista imperada no sistema educacional através da Reforma Benjamin Constant, a educação passou a se organizar a partir da junção de matérias científicas e tradicionais, escolas essas que continuavam destinadas às elites. Tanto que em meados de 1890 o percentual de 
analfabetos no Brasil chegava a $85 \%$ da população, vindo a cair para $65 \%$ em 1929 , sendo que esse número incluía brasileiros a partir de 15 anos de idade. A educação destinada às crianças simplesmente não se cogitava. Era o que se chamou de educação aristocrata.

Posteriormente, o desenvolvimento das sociedades urbanas e as necessidades comerciais e industriais, que provocou a migração do trabalhador do campo para a cidade, juntamente com as campanhas de alfabetização para fins eleitoreiros e mais tarde com a filantropia, pareciam aumentar o interesse das classes populares à educação primária, elevando, de acordo com Ribeiro (1982) a taxa de matrícula de adultos, de $12 \%$ para $30 \%$ em 1889.

A Era Vargas possibilitou, em 1930, a criação do Ministério da Educação e Saúde, das universidades no estado de São Paulo (1934) e do Distrito Federal (1935), representando um grande avanço à organização da educação no Brasil. Anteriormente, em 1932, ocorreu o movimento que ficou conhecido como "Pioneiros da Educação Nova", que defendia o direito universal, laico, público e de qualidade, da educação básica, fornecida gratuitamente pelo Estado, à população em idade escolar, denominando assim, a Escola Nova. Esse movimento, deu, à alguns educadores, o reconhecimento e luta por uma educação como direito de todos, dentre os quais se destacam Anísio Teixeira, Fernando de Azevedo, Paschoal Leme, Lourenço Filho, Roquete Pinto, entre outros. Nesse sentido: “ A Constituição de 1934 deu ênfase à educação, e os estados iniciaram um processo de reformas educacionais, cabendo à União fixar um plano nacional de educação e fiscalizar a aplicação de verbas destinadas à educação pelos estados e municípios".

Mais tarde, após o golpe militar de 1937, a política educacional trouxe consigo o ensino profissionalizante a fim de formar trabalhadores para a indústria e o comércio. Foram criadas as escolas técnicas, entre elas o conhecido grupo S: Senai, Senac, Sesc e Sesi. O que se vê a seguir, é cada vez mais, movimentos em favor da democratização da educação. Já na Segunda República (1945-1964), houve a expansão da escolarização básica até culminar na Lei de Diretrizes e Bases da Educação Nacional, Lei no 4.026/1961. Em 1968, foi publicada uma nova (LDB), Lei $n^{\circ} 5.540 / 1968$, que instituiu a reforma do ensino superior no Brasil, entre outras questões e mais à frente, outra LDB, dessa vez a Lei $n^{\circ} 5.692 / 1971$, que por sua vez, trouxe reforma para o antigo $1^{\circ}$ e $2^{\circ}$ graus.

A Constituição Federativa de 1988 ampliou, definitivamente, a oferta de ensino universal do Brasil, inclusive para acesso às crianças na educação infantil. Após a apresentação de várias propostas de substituição da LDB de 1971, em 1996, após a intervenção do então Senador Darcy Ribeiro, aprovou-se a LDB, Lei n 9.394/1996, em vigor até os dias atuais, com as devidas alterações de artigos relativos a cada questão em seu tempo, assim como o Plano Nacional de Educação (PNE) com novas diretrizes curriculares, 
normas e resoluções do então Conselho Nacional de Educação. A LDB, aplicada à educação constitui-se, portanto, como referência para organização do sistema de ensino público e privado brasileiro.

Àquela população obrigada a se instrumentalizar apenas para atender às exigências de escolarização proveniente da revolução industrial, agora, postula-se uma educação pósindustrial, com direito não apenas à educação primária ou profissionalizante, mas a formação de um sujeito cidadão, que pode dar prosseguimento aos estudos em universidades públicas ou privadas à sua escolha, ressalvados os devidos impedimentos por questões econômico-social. Se o acesso à educação na idade escolar não foi, de alguma maneira, oportunizado ao indivíduo, pode-se, ainda, ingressar nos cursos compactados (semestral, ciclos, grupos não-seriados - artigo 23 da LDB em vigor) o que permite o acesso à escola de sua preferência e próximo ao seu local de moradia ou de trabalho.

A avaliação da aprendizagem no Brasil ganha também novas possibilidades, na medida em que propõe uma forma cumulativa e contínua de mensuração do ensino aplicado ao estudante pelo professor; a possibilidade de realizar parte do ensino à distância; aceleração da aprendizagem para estudantes com atraso escolar; avanço para outras séries, mediante avaliação própria; aproveitamento de estudos; prevalência dos dados qualitativos sobre os quantitativos; possibilidade de recuperação paralela a outros níveis de ensino (artigo 24).

O principal a ser observado, segundo pondera Porto (2009) é que a atual Lei de Diretrizes da Educação Nacional, tem, por característica própria, a flexibilização do ensino, a democratização da gestão, a criação do Projeto Político Pedagógico (PPP), com a participação de toda a comunidade escolar, a saber: professores, alunos, pais, auxiliares de educação, a comunidade em geral (Conselhos Escolares) e entre os profissionais da escola, o Orientador Educacional, cujas especificidades de atuação serão doravante destacadas. No entanto:

Tais políticas e diretrizes, com raras exceções, não têm sido capazes de romper a tensão entre intenções declaradas e medidas efetivas. De um lado, estabelecem-se políticas educativas que expressam intenções de ampliação da margem da autonomia e de participação das escolas e professores; de outro, verifica-se forte crise de legitimidade dos estados, dificultando a efetivação de investimentos, por exemplo, em salários, carreira e formação do professorado, com a alegação de que o enxugamento do estado 
requer redução de despesas e do déficit público, o que acaba imprimindo uma lógica contábil e economicista ao sistema de ensino (Libâneo, 2001, p. 36)

Nesse sentido, as intervenções para uma educação que atenda as demandas humanas e sociais ficam renegadas a segundo plano, assim como o papel de agente inovador dos processos pedagógico-educativos, curriculares e organizacionais que transformem, não só a escola, mas os sistemas de ensino em geral, demarcados institucionalmente, tendo o professor como sujeito visível e imediato dos processos de escolarização integrado ao contexto social.

A nova realidade de adaptação dos sujeitos ao novo cenário mundial de desenvolvimento afetou a educação de maneira que, dos indivíduos por ela formados, se requer polivalência e flexibilidade não apenas com relação ao ensino, mas também à produção do trabalho. Assim, novas habilidades cognitivas, competências interpessoais são cada vez mais exigidas.

Entretanto, a formação do sujeito pensante, crítico e capaz de aprender continuamente, integrando competências locais, globais, ampliando conhecimentos, com qualidade, autonomia responsável, consciência ética e solidariedade, ainda é o ideal da educação escolar, na qual estão envolvidos, estudantes, Docentes, Coordenadores Pedagógicos, Diretores, Supervisores, Orientadores Educacionais, outros membros da comunidade escolar, em conjunto com as famílias e as demais esferas do poder público.

\section{Orientação Educacional: Origem histórica}

A Orientação Educacional (OE) surgiu nos Estados Unidos em meados do século $X X$, marcada pela necessidade de maior compreensão do educando, no ambiente escolar, como sujeito integral cuja vivência permeia aspectos educativos, sociais, com estruturas físicas, mentais, morais, estética, científica, religiosa.

Porto (2009) afirma que até meados do século XX, o educando ocupava papel secundário nos processos educativos escolares. Já naquela época, o sucesso no aprender era mérito do docente e os fracassos atribuídos aos alunos. Os tais processos educativos deixavam de fora tanto as vivências quanto as virtudes, as especificidades de cada indivíduo no ambiente escolar, assim como seus valores, seu universo sociocultural (Guimarães \& Silva Júnior, 2012; Lago, Mozzer \& Santibanez, 2013). 
A partir das novas exigências da educação do sujeito e as constantes reformas ocorridas nos processos de ensino, passou-se a dar mais atenção à formação integral do indivíduo, e sua realidade sociocultural, humana e profissional. É no bojo dessas mudanças que surge o advento da Orientação Educacional, com o objetivo de ampliar as ações quanto a ministrar assistência ao educando.

Foi Lourenço Filho (1897-1970), um dos precursores da educação brasileira, que, enquanto diretor do Departamento de Educação do Estado de São Paulo (1931), criou o Serviço de Orientação Profissional e Educacional, que veio a ser interrompido no ano seguinte, retomado na mesma época e extinto novamente em 1935, por Fernando Azevedo. A Orientação Educacional na escola era utilizada para designar um serviço auxiliar dos processos educativos, de forma simplista e pouco acadêmica. Dados mostram que em 1938, o Instituto Nacional de Estudos Pedagógicos (INEP) criou uma subdivisão, a qual ficou responsável pela implantação da Orientação Educacional no Brasil.

A Lei Orgânica do Ensino Secundário, instituída pelo Decreto-Lei nำ 4.424/1942, trouxe a determinação desse serviço em escolas de nível secundário, com a prerrogativa de observar e cooperar para que o aluno pudesse alcançar êxito nos estudos e na escolha profissional. Ao OE cabia a função de aconselhar o estudante e a família. Cabia-lhe ainda a função de cooperar com os professores, na cobrança da boa execução dos trabalhos escolares em classe, velar para que a recreação e o descanso dos alunos facilitassem a conveniência pedagógica. Em 1957, em São Paulo, foi realizado o primeiro simpósio de Orientação Educacional, que discutiu a implantação do serviço em escolas de ensino médio e no ano seguinte, em Porto Alegre, o segundo seminário, que abordou a organização e estrutura do serviço.

Em 1968, a Lei n 5.564, ampliou a extensão da OE para os níveis médio e primário, mas ainda com visão aconselhativa e assistencialista (individual ou em grupo) no âmbito escolar, com o objetivo de auxiliar o educando no seu desenvolvimento integral, agregando, de forma ordenada, as situações que trazem influência à formação e preparação para o exercício de opções básicas na vida.

A obrigatoriedade da OE em todas as instituições escolares veio com a criação da Lei n. ${ }^{5}$ 5.692, em agosto de 1971, com a criação do Serviço de Orientação Educacional (SOE), estabelecendo assim, relações de parceria entre a escola, os docentes, a comunidade e as famílias. O que não significa, no entanto, que a obrigatoriedade imposta seja, de fato, realidade nas escolas públicas e privadas até os dias atuais. Sua função abrigava orientação vocacional em cooperação com toda a comunidade escolar, era o que a lei dizia. Em 1973, a Lei oㅜ 72.846, regulamentou a antiga Lei oㅡ 5.564/1968, lei esta que 
tratou do exercício da profissão. É curioso notar que a OE sempre foi e é exercida mais por mulheres do que homens (Giacaglia \& Penteado, 2013).

É dentro da perspectiva de auxílio ao estudante na acepção mais vocacional que a Orientação Educacional se instaura nas escolas, atendendo ainda, aos objetivos dos resquícios da Revolução Industrial e à crescente necessidade de qualificação da mão de obra, com o compromisso de treinar alunos aos ensejos do mercado vigente à época. Nesse sentido, definitivamente, a escola não seria destinada somente às elites, mas abremse as portas para a população em geral, quando já era então o século XIX (Giacaglia \& Penteado, 2013).

A Orientação Vocacional clássica também surge nessa mesma época, preconizada por Frank Parsons (1874-1908), que na sua teoria, afirmava tratar-se de integrar homem e função na mesma perspectiva. As ideias dele permeiam até hoje, não apenas no trabalho dos Orientadores Vocacionais, mas também nos Orientadores Educacionais, prática que reduz o trabalho do segundo grupo a meros aplicadores de testes vocacionais idealizados pelos cientistas Binet e Simon. Esses testes, iniciados na França, foram amplamente disseminados também do Estados Unidos da América (EUA).

De acordo com Giacaglia e Penteado ( 2013), a prática da aplicação de testes psicométricos influenciou de tal forma a Orientação Educacional e os profissionais de Pedagogia que exerciam essa função na escola que, em 1951, por ocasião do encontro da Sociedade Americana de Psicologia, propôs-se a designação do termo "Counseling Psychology" aos profissionais da Psicologia, com a intenção de delimitar o campo de atuação em uma área que não dizia respeito ao campo da Pedagogia, confundindo-se com a Psicologia, nesse caso específico. Situação que durante um tempo gerou conflitos entre esses profissionais. Nos EUA o profissional de Orientação Educacional era chamado de "Educational Guidance", na França "Psychologie Scolaire".

O que se percebe afinal, é que ao longo da construção histórica da Orientação Educacional, a atuação do OE passou por várias transformações e sentidos devido à constante evolução das formas de educar e se adequar ao mundo 'dito moderno'.

Em um segundo momento, a Orientação Educacional adquiriu um cunho terapêutico e disciplinar e corretivo nas instituições escolares, para atender aos estudantes com 'inadaptação escolar ou comportamentos inadequados', vindo em seguida a trabalhar em caráter preventivo e humanista.

Nessa ciranda de períodos pelos quais a OE vivenciou ao longo dos anos, Grinspun (2012) separa e descreve três fases e logo depois aponta três que merecem destaque: fase romântica - na qual se pensava que a OE resolveria, como num passe de mágica, todos os problemas dos educandos, abarcando o maior número possível deles; fase objetiva - OE 
como prestadora de serviços em várias vertentes, principalmente impedindo que os alunos se envolvessem em problemas e, fase da prevenção - OE utilizada para se antecipar aos problemas, evitando conflitos. Cronologicamente, os períodos foram organizados da seguinte forma:

Período Implementador (1920 a 1941) - Começam a surgir os primeiros movimentos e a necessidade desse serviço no ambiente escolar, ainda que ligado à orientação profissional (recrutamento e seleção).

Período Institucional (1942 a 1960) - ocorre a institucionalização da OE obrigatoriamente nas escolas. O Ministério da Educação e Cultura inicia as propostas para formação em OE, nos cursos superiores.

Período Transformador (1961 a 1970) - Surge a Lei o 4.024/61 (caracterizada educativamente) e da Lei 5.540/48 (profissionalização). O aspecto preventivo é dessa época.

Período Disciplinador (1971 a 1980) - Através da Lei no 5.692/67, a OE, obrigatoriamente, deve incluir em seu trabalho o aconselhamento vocacional e contribuir com a organização curricular da escola, numa visão sociocoletiva, mas ainda assim atrelada com a da Psicologia. A seguir, a Lei oㅜ 72.846/73, regulamenta a profissão de OE e determina outras providências.

A escola, por sua vez, desenvolve políticas voltadas para a reprodução do sistema social vigente. Nesse sentido, os novos movimentos fora da escola, clamavam por mais atenção ao eixo social, com abertura às não-elites no interior das instituições educacionais. Assim, a própria OE passa a adquirir um cunho cada vez mais pedagógico.

Período Questionador (Década de 1980) - É justamente nesse período que a OE passa por um crivo mais questionador do seu papel frente à escola exigindo formação profissional e outras demandas. É um período mais crítico e consciente. Surgem os cursos de 'reciclagem', promovendo integração do OE com o corpo escolar, ou seja: “(...) procurando discutir objetivos, procedimentos, estratégias, critérios de avaliação, sempre voltados para o aluno" (Grinspun, 2012, p. 34-35).

As transformações que a Orientação Educacional sofreu ao longo do tempo, são fruto das mudanças a que a escola e a sociedade passaram. Uma escola antes excludente e seletiva, passou a ser mais compulsória e democrática. O que se viu a seguir é que a escola foi dividida em pública básica, técnica, superior e uma privada, permitindo à elite manter assim, seus filhos em escolas consideradas superiores às demais, separada por classe social, Giacaglia e Penteado (2013). 
A década de 80 representou um momento de grande dificuldade para os Orientadores Educacionais no Brasil. Tal situação ocorreu por diversos fatores: o descumprimento da Lei Federal no 5.692/71, que obrigava a presença de um OE nas escolas públicas; a ausência de concurso público para o setor; a deficiência de formação adequada para esses profissionais nos cursos de Pedagogia; questionamentos ideológicos e metodológicos do serviço; desvalorização do OE por parte das escolas e a ausência de clareza da sua atuação; Supervisores Pedagógicos começaram a atuar como OE; o desinteresse de novos formados na área.

A LDB no 9.394/1996 marca o resgate da importância da OE nos processos educativos, contribuindo assim, para o desenvolvimento integral do educando, preparo e exercício da cidadania e qualificação para o trabalho (Título II, art. 1). Dessa forma, observa, Grinspun (2012), a história da OE no Brasil sempre foi tecida de vários 'bordados pedagógicos', inicialmente de cunho terapêutico, até assumir sua forma legal de atuação.

A LDB, vigente no Brasil, com seus avanços e pressupostos, contudo, não traz a obrigatoriedade da presença do Orientador Educacional nas escolas, embora sua função e importância permaneçam nela citado. O artigo 64 determina:

A formação de profissionais de educação para administração, planejamento, inspeção, supervisão e orientação educacional para a educação básica, será feita em cursos de graduação em pedagogia ou em nível de pós-graduação, a critério da instituição de ensino, garantida, nesta formação, a base comum nacional.

Outra questão levantada por Giacaglia (2013), diz respeito à falta de clareza, na LDB sobre as funções do Orientador Educacional na escola, fato que pode levar outros profissionais, como o Coordenador Pedagógico a exercer a função sem ter o devido preparo, como acontece em alguns estados brasileiros. Nas escolas brasileiras a presença do OE é quase nula. O Distrito Federal, não obstante, é um dos Estados da Federação com maior número de profissionais.

\section{As especificidades do Serviço de Orientação Educacional - O que é? Onde? Para quem? Por quem? Como? Por que e para que?}

A Orientação Educacional pode ser definida como sendo um processo sistemático e complexo de assistência profissional que inclui métodos e técnicas com aportes 
pedagógicos e psicopedagógicos, capazes de levar o educando a compreender suas características individuais e do seu contexto em direção ao seu desenvolvimento pessoal e social.

As técnicas e métodos próprios da Orientação Educacional só devem ser utilizadas por profissional da área, não cabendo a outros profissionais da escola fazer uso deles. É necessário compreender para que e como utilizar cada uma delas.

O local de atuação do OE, que antes estava destinado a atuar em escolas públicas ou privadas, com o tempo ganhou destaque e importância também em empresas, no auxílio ao recrutamento e seleção de funcionários, voltados para o foco educativo no ambiente de trabalho. Pode atuar também em Organizações Não-Governamentais; na docência; desde que licenciado; instituições públicas e privadas.

É de suma importância destacar também, que o trabalho do Orientador Educacional, traz em si, uma forma peculiar de atendimento individual e familiar regido sob um Código de Ética, instituído pela Federação Nacional dos Orientadores Educacionais, em Curitiba, em 18 de novembro de 1978 e publicado no Diário Oficial da República Federativa em 05/03/1979, que trata da conduta profissional do OE, cuja função já àquela época, só podia ser exercida por profissional habilitado.

\section{O Orientador Educacional na Rede Pública de Ensino do DF}

Em 2010, a Secretaria de Estado de Educação do DF, publicou a Orientação Pedagógica (OP) do Serviço de Orientação Educacional, com diretrizes imprescindíveis ao trabalho nas instituições de ensino público. O documento foi elaborado por uma equipe de OE's do quadro da rede pública de ensino e com a colaboração de sugestões e observações de todos os Pedagogos- OE da rede, os quais foram consultados por ocasião das Coordenações Coletivas ocorridas quinzenalmente em cada Coordenação Regional de Ensino.

A OP traz considerações sobre o contexto histórico da OE no Brasil e no mundo, sua importância, pressupostos teóricos, fundamentação legal, perfil do OE, operacionalização da atuação e as ações que devem ser realizadas no seu dia a dia de trabalho. É um documento histórico e de grande relevância para a consecução do trabalho do OE. Percebe-se, no entanto que a OP em vigor carece de atualização, mediante as alterações que o próprio trabalho vem exigindo em constante movimento, ainda que tenha apenas 6 anos de formulação. 
Atualmente, a OE na SEEDF é coordenada pelo Núcleo de Orientação Educacional (NOE), vinculado à Subsecretaria de Educação Básica cuja operacionalização acontece em três níveis: Nível Central - composto por Pedagogos OE's os quais coordenam as atividades e determinações centrais da própria SEEDF para os profissionais que atuam em escolas públicas e Regionais de Ensino; Nível Intermediário - composto por um Pedagogo $\mathrm{OE}$, atuando como Coordenador Intermediário nas Regionais de Ensino, escolhido democraticamente por seus pares; Nível Local - composto por Pedagogos OE's em exercício em instituições educacionais da rede pública de ensino, incorporando suas ações ao processo educacional global, na perspectiva da educação em e para os direitos humanos, cidadania, diversidade e sustentabilidade, objetivando a aprendizagem e o desenvolvimento integral do estudante. A atuação do Pedagogo OE, está sob a responsabilidade de profissionais habilitados e concursados, para a função, na forma da lei.

\section{O Profissional de Orientação Educacional}

No Distrito Federal, até bem pouco tempo, o OE era considerado, dentro da Carreira Magistério Público do DF, como um Especialista de Educação Básica. Contudo, com o advento da Lei no 5.515, de 13 de maio de 2013, que reestruturou a Carreira fez alterações na denominação do cargo, que passou a ser chamado de Pedagogo-Orientador Educacional (Pedagogo-OE). É o que consta na Seção II - Da estrutura, inciso I e II, da lei em epígrafe. As atribuições da função foram definidas pela Secretaria de Estado de Administração Pública e da Secretaria Estado de Educação do DF.

As formas de ingresso na carreira se dá mediante concurso público (provas e títulos), podendo atuar nos anos iniciais e finais do Ensino Fundamental, Ensino Especial, Educação Infantil, 1ำ $2^{\circ}$ e $3^{\circ}$ Segmentos da Educação de Jovens e Adultos, Ensino Médio e Educação Profissional, Centros de Línguas. Desde a lei, profissionais formados em outras áreas do conhecimento, mas sem formação em Pedagogia, não podem atuar como OE nas escolas da rede pública de ensino, mesmo que a formação seja em nível de pós-graduação.

Por determinação da Resolução CNE/CP no 01, de 15 de maio de 2006, que instituiu Diretrizes Curriculares para o Curso de Graduação em Pedagogia, licenciatura, os cursos, que antes permitiam a habilitação do Pedagogo em Supervisão, Orientação Educacional ou Administração Escolar, agora passa a formar Docentes para a Educação Infantil, anos iniciais do Ensino Fundamental, nos cursos de Ensino Médio, na modalidade Normal, e em cursos de Educação Profissional na área de serviços de apoio escolar, assim como nas áreas nas quais sejam previstos conhecimentos pedagógicos (art. $2^{\circ}$ ). 
O artigo 10 da Resolução em questão extingue todas as habilitações em cursos de Pedagogia anteriores a ela. A partir de então, Administração ou Gestão Escolar, Orientação Educacional, Coordenação Pedagógica e Supervisão Pedagógica passam a ser ministrados em nível de pós-graduação em instituições credenciadas e autorizadas pelo Ministério da Educação.

Dentro do perfil considerado adequado para o profissional de OE, está a capacidade de interação com pessoas (pais ou responsáveis, estagiários, pessoas da comunidade em geral dentro e fora da escola) e estudantes de diferentes tipos e faixas etárias. $\mathrm{Na}$ classificação das profissões, a de OE está no mesmo patamar de enfermeiros, psicólogos, assistentes sociais, fonoaudiólogos, fisioterapeutas, médicos, por se tratar de profissionais voltados para o ato de ajuda, auxílio. O que deve prevalecer, afinal, é a oferta de boa formação ao profissional dentro dos cursos, além de boa remuneração e valorização, sem contar com a formação continuada, tão importante a quaisquer profissionais em áreas correlatas ou não.

Não resta dúvida da importância da presença do OE no ambiente escolar. Não como um 'bedel', nome pejorativo que comumente se dá ao Pedagogo-OE, que em muitos estabelecimentos de ensino, atua, ora como 'apagador de incêndio', ora como 'disciplinador nos corredores', 'faz tudo', 'animador de turma', ou aplicador de dinâmicas para 'motivar' estudantes, 'falar sem vergonha/receio sobre qualquer assunto com os pais e alunado' ou ainda, como 'produtor cultural' nas atividades festivas. Atividades essas que não coadunam com as atribuições previstas ao cargo.

A Orientação Educacional está para além do meramente imposto às instituições educativas, no seu Código de Ética ou mesmo na Orientação Pedagógica, documento oficial de diretriz ao trabalho do SOE nas escolas públicas do DF, mas enseja, contribuir para a formação da cidadania, formação para o trabalho, para a vida, para as interações sociais, individuais e coletivas e formação integral do indivíduo, como sujeito ativo na sociedade em que vive. A perspectiva contextualizada tanto do Pedagogo-OE quanto dos demais profissionais de educação demanda a consideração do ser humano total, com suas crenças, valores, características socioculturais, afetivas, expressão individual, na perspectiva ativa dos sujeitos.

\section{Atribuições do Serviço de Orientação Educacional}

Giacaglia (2013), afirma, em seu livro "Orientação Educacional na prática”, que a Orientação Educacional é um serviço pouco conhecido, mesmo no ambiente escolar, assim 
como sua importância. Mas não apresenta os fundamentos de tal afirmativa. Particularmente, pensamos que, até pela história de luta por estruturação da profissão, tal fala não procede entre aqueles que atuam na área, pelo menos em relação ao Distrito Federal.

O que existiu, por longo período, é que, devido a não exigência do OE no ambiente escolar no Brasil, nem todas as escolas o tem no seu quadro técnico-pedagógico, mas isso não significa que, mesmo nas escolas onde não exista esse profissional, sua importância e existência estejam apagadas ou em menor grau de importância seja em escolas, como até em empresas, hospitais, organizações não-governamentais.

No Distrito Federal, as atribuições do Serviço de Orientação Educacional estão previstas no Regimento Escolar das Escolas da Rede Pública de Ensino, através da Portaria no 15, de 11 de fevereiro de 2015 e publicada no Diário Oficial do DF em 13 de maio de 2015 (pag. 10 a 33).

No Título III - Da organização pedagógica, Das equipes de apoio e dos recursos, Capítulo I - Da organização Pedagógica, no seu art. 118, parágrafo 1ํ, a Orientação Educacional aparece entre os profissionais da unidade escolar (inciso II - Equipe de apoio, letra b.). O artigo 126 da Subseção II, denomina a OE como um:

Serviço especializado, desempenhado pelo Pedagogo-Orientador Educacional, para o acompanhamento e o apoio dos profissionais da educação, dos estudantes, seus familiares e articulação da comunidade escolar e da rede externa (rede social ou rede de apoio), quanto ao processo de ensino e aprendizagem e das relações humanas que o cercam.

O artigo 127 deixa claro a necessidade de atuação do Pedagogo-OE em princípios de ação coletiva, contextual, em plena integração com o Projeto Político Pedagógico (PPP) da instituição educativa, ensejando ao desenvolvimento integral do estudante, na sua aprendizagem, criticidade, participação, criatividade e protagonismo, interagindo com o meio sociocultural, cidadania, com responsabilidade.

De acordo com o referido Regimento, são atribuições do Pedagogo-OE:

- Participar da elaboração do PPP, da formulação do currículo escolar da educação básica e dos processos avaliativos, processos disciplinares;

- Elaborar Plano de Ação do SOE anualmente, levando em conta processos sociais, políticos e econômicos; 
- Participar das coordenações coletivas junto com a equipe escolar quinzenalmente e de coordenação própria, com outros OE's, quinzenalmente;

- Planejar e implementar as ações do SOE;

- Realizar ações integradas com a comunidade escolar, levando em consideração os temas transversais;

- Contribuir para a melhoria do ensino e da aprendizagem e os processos que impedem o sucesso escolar;

- Coordenar o processo de informação educacional e profissional;

- Supervisionar estágios na área de OE;

- Apoiar e subsidiar órgãos colegiados como: Conselho Escolar, Grêmio Estudantil, Associação de Pais e Mestres, entre outros;

- Articular parcerias diversas (redes sociais e setores da SEEDF), e órgãos de proteção à criança e ao adolescente;

- Participar de programas de formação continuada;

- Elaborar relatório de sua ação anualmente;

- Emitir parecer técnico dentro de sua área de atuação;

- Articular ações com a Equipe Especializada de Apoio à Aprendizagem e Salas de Recursos, destinadas a alunos com necessidades educacionais especiais;

- Desenvolver ações visando a cultura de paz na escola.

Como se vê, são inúmeras e diversificadas as atribuições colocadas ao PedagogoOE no ambiente escolar no DF, cuja atuação nas escolas públicas, está delegada, na sua maioria, a apenas um profissional por Unidade de Ensino, seja por turno ou modalidade, pois, como já dissemos, ainda há escolas no DF que não possuem OE e mesmo naquelas onda existe, as atividades são delegadas a apenas um profissional para um grande número de estudantes, o que, em muitos momentos, inviabiliza um trabalho mais efetivo.

\section{As influências Filosóficas ao trabalho do OE}

As práticas pedagógicas que se concretizam no ambiente escolar acontecem articulando Pedagogia, o que, segundo Luckesi (2011, p. 33) "nada mais é do que uma concepção filosófica da educação" e essa concepção é que deve conduzir tais práticas.

A Filosofia surgiu como uma forma de o indivíduo buscar conhecimento e compreender o mundo real (existência, significados, sentidos, ação e reflexão, coerência) para além dos fenômenos da natureza ou fenômenos divinos, em todas as suas dimensões, 
seja para suscitar o pensar e evitar a massificação (condicionamento) das ideias, seja para possibilitar uma melhor interpretação das vivências cotidianas, de forma sistêmica, histórica, efetiva, ainda que, em muitos momentos, tenha sido utilizada para servir aos interesses das classes dominantes. O pensar crítico e reconstrutivo, fora do senso comum está presente no ato de filosofar desde os primórdios do seu surgimento.

A educação, por sua vez, configura-se como uma necessidade do homem de transformação social. Luckesi (2011, p. 45) afirma que tal necessidade advém de uma constante reflexão filosófica sobre a educação, assim: " Enquanto a educação trabalha com o desenvolvimento dos jovens e das novas gerações de uma sociedade, a filosofia é a reflexão sobre o que e como devem ser ou desenvolver estes jovens e esta sociedade". Ao longo da história da filosofia, os Filósofos da era pré-socrática, sofistas, Sócrates e Platão eram considerados educadores e assim se declaravam como tal.

À escola, na qual o OE está inserido, cabe uma reflexão constante acerca da sociedade, seus indivíduos, seus sujeitos, sua maneira de ser e agir no ir e vir da vida, seus anseios, desejos e aspirações, sua cultura, crenças, suas formas de vida.

Pensar o papel da filosofia nos processos educativos, permite a consecução de ações conscientes, críticas e favoráveis ao desenvolvimento de um ser que compreenda sua importância e função no mundo, através da percepção das relações humanas na sua totalidade. Nesse sentido, ação pedagógica e filosofia são indissociáveis. Os desafios para a educação na contemporaneidade, pressupõem também, aporte híbrido com outras ciências, entre elas: a Psicologia, Sociologia, Biologia, Antropologia, Artes, Economia, Geografia Humana, e muitas outras.

Entender os pressupostos filosóficos na educação possibilita ao OE contribuir para o fazer pensar nos processos de ensino e aprendizagem nas instituições de ensino, através da mediação na construção das concepções de mundo, os quais sistematizam, transmitem, assimilam e produzem mutuamente, culturas, com sentido e significado pertinente às práticas humanas. Assim, não se concebe um indivíduo passivo, acrítico, preso à alegoria do mito da caverna (Platão 428-348 a.C.), mas um indivíduo integrado ao seu meio de origem, com seus vínculos diversos (sua subjetividade, constituição e características, natureza humana e sociocultural, historicidade, sociedade, meio político). Nisso, Luckesi (2011, p. 126) pondera que o educando:

(...) tem uma natureza físico-biológica que se constrói pelo crescimento, tem uma inteligência que adquire patamares complexos de reflexão pela sua relação com o meio e pela atividade; 
tem maior ou menor capacidade de apropriar-se dos conhecimentos e habilidades, dependendo de suas vivências e convivências.

O Pedagogo-Orientador Educacional, a partir do papel que ocupa no ambiente educativo e social, assim como os demais profissionais com os quais atua, estudantes, familiares, cada um deles possuindo uma natureza social e histórica, que perpassam as relações sociais (ações, reações, hábitos e atitudes, condutas em forma de norma ou não, necessidades especiais), são sujeitos ativos no ambiente ao qual fazem parte ou tem parte. São fruto das tramas sociais que constroem, reconstroem ou vice e versa, seres humanos sociais (vivência e história) em constante sobrevivência e transformação. Nessa perspectiva, o processo de filosofar traz à tona "problemas propostos pelo nosso existir" (Aranha, 2006, p. 25), para que, a partir "da concepção de humanidade, que orienta a ação pedagógica, para que não se eduque a partir da noção abstrata e atemporal" do indivíduo em si mesmo. 


\section{III - PSICOLOGIA DO DESENVOLVIMENTO}

A ideia de cidadania parecia, então, associar-se ao exercício pleno num Estado de direitos, e ao exercício do convívio entre iguais e em sociedade, mas também a um exercício de diferenças entre iguais.

(Botelho \& Schwarcz, 2012, p.10).

Esta sessão tem como objetivo destacar a concepção histórica e metodológica da Psicologia do Desenvolvimento, seus conceitos, desafios e possibilidades. Além disso, aborda também temas como Desenvolvimento humano na adolescência e Adolescência e Socioeducação.

\section{Breve histórico da Psicologia do Desenvolvimento}

A Psicologia do Desenvolvimento é uma ciência voltada prioritariamente para o estudo interdisciplinar dos fenômenos que envolvem o desenvolvimento humano em seus processos biopsicossocial internos (endógenos) e ambientais (exógenos) e as alterações que provoca no comportamento ocorridas dentro do período que se estende ao longo da vida (Biaggio, 2015; Dessen \& Costa Júnior, 2005; Papalia, Olds \& Feldman, 2006; Schraml, 1977). Nesse sentido, agrega áreas da Psicologia, tais como: Personalidade, Aprendizagem, Social, Psicopatologia, Percepção, Fisiológica e ainda outras ciências, como a Antropologia, Genética, Sociologia, Filosofia, Pedagogia.

Diferentes inter-relações estão presentes nos sistemas que envolvem o desenvolvimento do indivíduo. Dessa forma, estão em constante contato com estruturas pessoais de comportamento e com o ambiente que o cerca permeado por crenças, valores, mitologias e instituições de todos os tipos e modos. A manutenção de sua saúde biofísica, social e mental determina sua maneira de ser e existir no mundo, mediado pelas relações que estabelece.

Os processos de desenvolvimento são marcados por fatores contínuos e descontínuos e podem ser compreendidos como pertencentes às peculiaridades do indivíduo em interação com o seu contexto que provoca mudanças cotidianas no seu transcurso de vida. Representa assim, na concepção de Dessen e Costa Júnior (2005): "uma reorganização contínua dentro da unidade tempo-espaço que opera o nível das 
ações, percepções, atividades e interações do sujeito com o mundo, sendo estimulado ou inibido por meio das interações de diferentes participantes do ambiente da pessoa" (p. 11).

As crescentes mudanças ocorridas no meio ambiente ecológico, socioeconômico e tecnológico têm impulsionado tanto qualitativamente quanto quantitativamente, ao longo das últimas décadas, as pesquisas sobre desenvolvimento humano. Isso sem dúvida exige também uma interação cada vez maior com outras ciências investigativas, objetivando a melhoria dos processos educacionais, de saúde e bem-estar humano.

Estudar os diversos fenômenos que implicam no desenvolvimento do sujeito ao longo de seu ciclo de vida, significa, antes de tudo, reconhecer as contribuições de pensadores que deram fundamento filosófico à concepção do homem e sua evolução, antes mesmo que a Psicologia do Desenvolvimento fosse considerada como ciência, no século XX. Nesse grupo está Platão (integrante dos filósofos da natureza, 428-348 a.C.) John Locke e Jean Jacques Rousseau, pensadores da Era Moderna, (1632-1704 e 1712-1778, respectivamente), I. Kant (1724-1804), entre outros.

Platão entendia que no homem, desde a infância, já é possível perceber ou antecipar suas propriedades e condição de habilidade, as quais são inatas e é o que determina, desde cedo, os papéis que ocupará na sociedade. John Locke, considerado como o lluminista Inglês, afirmava que o homem vinha ao mundo como uma 'tábula rasa' ou como um papel em branco e que o convívio social e a educação seriam capazes de formar seu caráter e habilidades, assim como a função social no decorrer da vida. Já Rousseau, precursor da Revolução Francesa, entendia a existência humana como um 'nobre selvagem', denominado na sua pedagogia de Emílio. Segundo ele, esse homem considerado nobre passa a ser influenciado negativamente a partir das estruturas educacionais propostas pela civilização (Schraml, 1977).

Fröbel, fundador do jardim de infância, Kant e Herbart, filósofos e pedagogos no início do século XIX, também podem ser considerados como estudiosos precursores dos estudos da psicologia do desenvolvimento pré-científica (p.3).

Nos primeiros estudos sobre o desenvolvimento humano, aponta Biaggio (2015), as pesquisas eram direcionadas em sua maioria à infância e adolescência, ainda que se tivesse claro que o desenvolvimento acontece ao longo de todas as fases da vida. Contudo, os estudos mais contemporâneos enfatizam também a velhice como sendo objeto de estudo com igual importância.

É essencial destacar, no entanto, que as mudanças de comportamento ocorridas durante o ciclo de vida humana são marcadas pelo contexto social e histórico e é dentro dessa perspectiva que se dá o desenrolar dos processos psicológicos. Da mesma forma, 
são os acontecimentos que marcam o desenvolvimento humano do indivíduo e não simplesmente a passagem de tempo.

O próprio desenvolvimento humano é considerado mutante, visto que se adapta ao indivíduo em seus aspectos internos e externos em constante alteração. Nesse sentido, Papalia (2000) qualifica em dois os tipos de mudanças de desenvolvimento humano: quantitativo, que ocorre à medida em que os progressos vão surgindo e podem estar ligados às funções fisiológicas do indivíduo e, qualitativo, são aquelas mudanças ou fenômenos que acontecem para além do previsto com aquele indivíduo dentro de expectativas individuais.

Ao analisar as etapas da evolução no campo da Psicologia do Desenvolvimento, Ziegler (citado por Biaggio, 2015) aponta três fases com características básicas interrelacionadas desse movimento e seus respectivos estudiosos:

1a Fase (1920-1939) - período marcado pelo Conteúdo Concreto (Murchison, 1931); Metodologia descritiva e normativa; Teoria da maturação (Gesell).

Nessa fase, o objeto de principal interesse concreto diz respeito à observação das mudanças comportamentais decorrentes do avanço da idade. Daí a ênfase baseada na observação natural do indivíduo, e a descrição de tais mudanças. Na esfera teórica, baseada na maturação, igualmente ocupa-se da descrição do acontecimento e não procura explicar as causas que impulsionaram a alteração no comportamento.

2a Fase (1940-1959) - Conteúdo Intermediário (Carmichael (1946); Metodologia Correlacional; Teoria de estudos funcionais.

Abrangendo a concretude da fase anterior e o abstrato dessa fase seguinte, aplicase a metodologia que inter-relacione os aspectos observados, mas sem gerar conteúdo teórico. Entretanto, foi justamente nessa época que começaram a surgir as concepções de Piaget e Freud sobre o desenvolvimento humano.

3a Fase (1960) - Conteúdo Abstrato (Stevenson, 1963), Reese e Lipsitt (1970), Metodologia Experimental e Teoria da Aprendizagem social (Sears, Miller, Dollards, Mowrer, Banduram Bijou).

Já nessa fase, se inicia o interesse por explicar as causas que impulsionaram as mudanças de comportamento do indivíduo. Utiliza-se então o método experimental como forma de validar e tornar fidedigna as técnicas aplicadas. A teoria passa a enfatizar a aprendizagem social como sendo de grande importância para explicar as mudanças no comportamento humano.

Piaget (1896-1934) é apontado como um dos grandes nomes ligados à Psicologia do Desenvolvimento. Seus estudos nessa área, ocorridos a partir da década de 1920, 
influenciaram em grande medida os estudos no Brasil, o qual teve suas pesquisas reconhecidas primeiramente no Brasil em relação a países como Estados Unidos da América, devido à influência positivista, naturalista e experimentalista seguida pelos Psicólogos americanos, além da deficiência de rigor metodológico com inerência clínica detalhista utilizada (Coll \& Martí, 2004, p. 46).

$\mathrm{Na}$ verdade, os estudos de Piaget estavam voltados para o desenvolvimento da criança de uma forma geral, ou seja, para os aspectos universais infantis ao invés dos aspectos individuais. Por esse motivo, acreditava que o desenvolvimento está ligado à esfera de maturação em interação com a experiência que a criança vai adquirindo de acordo com a sua faixa etária.

Entretanto, diferentemente dos estudos realizados por Stanley Hall, Piaget baseou seus estudos na observação clínica e em situações experimentais. Suas pesquisas são consideradas de grande importância para os estudos sobre desenvolvimento humano e aprendizagem principalmente nos seus aspectos cognitivos. Em suma, Piaget "concebe o desenvolvimento como uma sucessão de três grandes períodos caracterizados cada um por suas estruturas, cada uma das quais surge da precedente, integra-se e prepara a seguinte" (Coll, Marchesi, Palacios \& Cols, 2004, p. 47).

Os três fatores aos quais Piaget se refere e que segundo ele explicam 0 desenvolvimento são: a maturação, a experiência com os objetos e a experiência com as pessoas, sem os quais não há desenvolvimento. Nesse sentido, sua concepção de desenvolvimento é interacionista, já que se apoia na relação entre o indivíduo e o ambiente, buscando a equilibração do sistema psicológico e a adaptação ao meio.

Freud também operou grande influência nos estudos do desenvolvimento humano, ao formular hipóteses sobre as experiências iniciais do humano, assim como John Watson, fundador do movimento behaviorista que realizou experimentos a partir de teorias da aprendizagem. A partir de então estabeleceu-se os estudos da moderna psicologia infantil.

Schaffer (2009) conceitua desenvolvimento humano como sendo as mudanças contínuas e sistemáticas vividas por um indivíduo no decorrer de sua trajetória de vida. Nesse sentido, o desenvolvimento pode ser causado segundo processos de maturação, ou seja: "corresponde ao desenvolvimento biológico do indivíduo de acordo com o plano contido em seu código genético - material hereditário passado pelos pais aos filhos na concepção" (p.2) e; aprendizagem, capaz de produzir mudanças permanentes nos sentidos, pensamentos e comportamentos a partir das experiências vivenciadas. 


\section{O Desenvolvimento Humano na Perspectiva Histórica}

Os estudos e pesquisas sobre o desenvolvimento humano tiveram seu início com o reconhecimento tanta da infância e adolescência como períodos peculiares. O interesse principal foi sempre com a interação contínua do sujeito nos seus aspectos orgânicos e com o seu contexto (Biaggio, 2015; Coll, Marchesi \& Palacios, 2004; Dessen \& Costa Júnior, 2005; Papalia \& Olds, 2000).

Nos relatos sobre a infância que antecederam os tempos pré-modernos, a criança não ocupava lugar de importância no universo adulto, e por esse motivo, possuía pouco ou nenhum direito. Até o século IV d.C. (DeMause, 1974), mostra que os pais eram autorizados a matar seus filhos se eles apresentassem algum tipo de deficiência, fossem ilegítimos ou indesejados. Mais tarde, aos meninos eram destinados ao treinamento militar a fim de que servissem em guerras, submetidos a situações de quase tortura como forma de adquirirem a dureza que a guerra exigia.

Toda essa suposta barbárie em relação à infância ocorrida nas cidades de Cartago, Roma ou Esparta devia-se ao fato de que as crianças eram consideradas como possessão da família que dela podia dispor da maneira que melhor atendesse aos seus interesses. Somente na Europa Cristã, por volta de XII d. C, o infanticídio passou a ser considerado crime. A partir disso, leis e regulamentos foram criados contra o trabalho infantil, educação sistematizada e serviços de assistência social destinados à criança (Mussen, Conger, Kagan \& Huston, 1988).

Na Idade Média, conforme analisou o historiador Philippe Ariés em 1962, as crianças eram retratadas comumente acompanhando os pais em tarefas de trabalho adulto ou em festas, ou mesmo vestidas e tratadas como adultos em miniatura. Entretanto, tal concepção não prevalece, pois, estudos posteriores realizados pelo psicólogo David Elkind em 1986, baseado em pesquisas bíblicas, assim como em escritos antigos gregos e romanos, comprovam que as crianças eram reconhecidamente tidas como de natureza especial.

$\mathrm{O}$ exame na autobiografia, registros diários e literaturas conferidas à Linda A. Pollock no século XVI, "argumenta enfaticamente que as crianças sempre foram vistas e tratadas de maneira diferente dos adultos" (Papalia, 2000, p. 30).

A preocupação com o bem-estar da criança foi um dos fatores que impulsionaram o início dos estudos sobre a psicologia da criança no início século XX. G. Stanley Hall é considerado um dos pioneiros no estudo científico da criança e do adolescente. Utilizandose de questionários nos quais indagava sobre as atividades do seu cotidiano e quais interesses tinham, "A meta de Hall era descrever as variáveis épocas da ocorrência e 
sequência no desenvolvimento, e foi um dos primeiros a aplicar mensurações objetivas a grandes números de crianças" (Mussen, Conger, Kagan \& Huston, 1988, p. 13).

Dessa forma, as primeiras pesquisas buscavam reunir informações descritivas que indicassem como se dá o desenvolvimento normal da criança, ligadas à faixa etária, seja em interação com outras faixas ou individualmente. Pretendia-se também estabelecer em que medida o desenvolvimento humano depende da maturação e da hereditariedade e até mesmo o estímulo que ambiente exercia sobre o desenvolvimento infantil. Dessa maneira:

a psicologia do desenvolvimento, enquanto disciplina científica que procura explorar, descrever e explicar os padrões comportamentais de estabilidade e mudança, expressos pelo indivíduo durante o seu curso de vida, foi conquistada ao longo do século $X X$, a partir da adoção de paradigmas metodológicos inspirados no positivismo e nas ciências naturais. (Dessen \& Costa Júnior, 2005, p.20).

Desde então, os estudos sobre o desenvolvimento humano abrangem o indivíduo da concepção à adolescência, suas variáveis, até atingir a maturidade. O alvo principal envolve a explicação do que, como e porque há ocorrência de mudança, continuidade e descontinuidades ou desvios, organizados em processos evolutivos em distintos aspectos do desenvolvimento no seu caráter, biológico, cognitivo, afetivo, social, sexual, moral, histórico e cultural.

\section{O caráter Histórico-cultural do Desenvolvimento Humano em Karl Marx e Vigotski}

Karl Marx (1818 - 1883) foi um filósofo materialista, movimento que considerava a matéria como substância fundamental e mais importante que qualquer ser ou substância. Esta perspectiva ponderava que o pensamento se desenvolve a partir da matéria em seu elevado nível de evolução. Cria ainda que Deus (entendido como ideia) é uma criação dos homens Cotrim (2013). Entre as suas principais obras de Marx e Engels destacam-se: A Ideologia Alemã, O manifesto comunista, A miséria da filosofia, Crítica da economia política, O capital, entre outras.

Marx deu importância primordial à ideia de trabalho e homem. Para ele, o trabalho é capaz de transformar o homem, como um ser social que é. À propósito, a trajetória de Marx e suas obras têm grande relevância para a Psicologia Histórico-Cultural. Isto porque este filósofo é precursor do entendimento de que o homem e a construção do seu conhecimento 
são formados em consonância com a vida e a realidade social, econômica, política e histórica. Nesse sentido, a explicação para os processos de satisfação das necessidades humanas e a produção do conhecimento são a base da construção histórica do sujeito em sua relação com o outro. Marx construiu boa parte de suas concepções em conjunto com Friedrich Engels (1820 - 1895). Ambos desenvolveram o método dialético.

As ciências sociais contemporâneas, entre elas a Psicologia, foram profundamente influenciadas pelas ideias de Marx, principalmente no que diz respeito à compreensão da totalidade do homem em sociedade (determinação das relações e sua influência sobre a vida como um todo: social, econômica, política). Na sua obra "O 18 Brumário de Luís Bonaparte", Marx declara que, embora os homens façam sua própria história, entretanto, não a fazem segundo escolha pessoal. Esses processos ocorrem na medida em que se defrontam diretamente com circunstâncias legadas ou transmitidas pela historicidade de uma a outra geração.

Compreender a história do homem social a partir das condições materiais à qual está sujeito é o principal fundamento do chamado Materialismo Histórico ou materialismo dialético criado por Marx, envolvendo três correntes básicas àquela época: a filosofia alemã, a economia política inglesa e a teoria política francesa. Segundo ele, o homem não é um ser abstrato, nem deve ser visto de maneira isolada do seu contexto histórico social, fora das relações humanas, pois é, essencialmente, fruto de suas interações: agir, pensar, sentir, comportamentos, trabalho e produção material. Assim, o indivíduo se manifesta de acordo com aquilo que é, e esse ser, advém de suas vivências sócio-históricas. Ao produzirem seus meios de subsistência, os sujeitos constroem a si mesmos como indivíduos, sendo isso o que os constitui.

Deste modo, o desenvolvimento histórico-social acontece na medida em que os meios de produção vão mutuamente se modificando. A ação humana e sua interferência no processo histórico, não se seguia por razão ou espírito, mitologias ou religiosidades). Nessa direção, Cotrim (2013, p. 297) declara que: "O pensamento de Marx teria um grande impacto no mundo contemporâneo, em termos teóricos e práticos, inspirando correntes filosóficas, movimentos operários e revoluções. E suas ideias, por suas implicações políticas, ainda são objeto de muitos estudos e acaloradas discussões" (Cotrim, 2013, p. 297).

Lev Seyonovitch Vigotski nasceu em 1896 em Orcha, Byelorussia. Para Vigotski, importante pioneiro da teoria sociocultural, o desenvolvimento humano é fruto de processos interiores socialmente guiados e das experiências adquiridas mediante a transmissão cultural passada de uma a outra geração e assim sucessivamente. 
Vigotski acreditava também que a educação é o processo pelo qual os indivíduos são humanizados. Assim, a escola funciona como um laboratório no qual se pode estudar e dimensionar culturalmente as especificidades humanas e o seu desenvolvimento enquanto tal e, ao mesmo tempo, produzir aprendizagens. Dessa forma, “... não apenas a natureza influi na conduta humana, como também as pessoas modificam suas próprias condições de desenvolvimento" (Coll, Marchesi, Palacios \& Cols, 2004, p. 97).

Partindo da perspectiva genética, para Vigotski, tanto a conduta humana quanto o desenvolvimento de processos psicológicos humanos obedecem a quatro domínios: o filogenético, o sociogenético, o ontogenético e o microgenético.

O domínio filogenético diz respeito à história de evolução da espécie. O sociogenético ou histórico cultural resulta do entendimento do indivíduo como sendo parte de um determinado grupo, na qual ocorrem constantemente mudanças na cultura, nos valores, normas e tecnologias. O domínio ontogenético corresponde ao desenvolvimento do indivíduo no período entre o seu nascimento até sua morte. E por fim, destacamos o domínio microgenético, que consiste naquelas mudanças ou transformações que ocorrem em períodos considerados relativamente curtos, durante todo o tempo em que o indivíduo realiza suas atividades. Diferentemente daquelas que ocorrem em períodos mais longos, como no caso do desenvolvimento ontogenético.

O desenvolvimento humano na perspectiva histórico cultural de Vigotski permite ao indivíduo mais do que adaptar-se aos fenômenos ocorridos à sua volta, mas apropriar-se deles e fazê-los seus, influenciar e ser influenciado, ou seja:

Enquanto a adaptação implica um processo de modificação das faculdades e das características dos indivíduos por exigências do meio - ou assim pode ser definido o conceito clássico de adaptação na lógica do determinismo darwiniano, a apropriação tem como resultado a reconstrução, por parte dos indivíduos, de faculdade e modos de comportamento desenvolvidos historicamente. (Coll, Marchesi, Palacios \& Cols, 2004, p. 98).

Nesse processo de apropriação, o sujeito percebe-se ativo em interação com objetos e outros indivíduos, a partir dos quais constitui-se pessoa. Semioticamente falando, significa que o sujeito passa a fazer usos de diversas linguagens para a resolução de problemas, conferindo-Ihes significado, em função dos seus interesses, ideias, conhecimentos, características pessoais e experiências adquiridas. O sujeito passa então a interiorizar conteúdos e ferramentas psicológicas obtidos culturalmente. 
A atividade humana como um fenômeno mediado por símbolos e ferramentas é uma das principais contribuições de Vigotski à compreensão do desenvolvimento humano. Tal contribuição é genuinamente reconhecida pela Psicologia do Desenvolvimento. Envolvidas em seu meio ambiente, as pessoas, ao se relacionarem através de formas superiores de comportamento, modificam-se e modificam seu meio ambiente concomitantemente. Foi Vigotski, por sua vez, quem identificou a Psicologia Sócio-Histórica como Teoria HistóricoCultural, declara Ozella, (2003). Foi a maneira encontrada pelo homem de satisfação das necessidades junto com outros homens (p. 8). Os quais tem suas características e potencialidades forjadas dialeticamente pelas relações sociais que estabelece no tempo e no espaço histórico no qual vive.

As ferramentas, por outro lado, permitem a regulação e transformação da natureza e, consequentemente a si próprias e uns aos outros. Linguagens, falas, pensamentos e as ações humanas à medida em que se desenvolvem mutuamente, resultam na criação e compartilhamento de signos construídos socialmente a partir das interações sociais nas quais o indivíduo mantém relações próximas. A este propósito, declara Dias (2014, p. 26): "É exatamente essa capacidade de lidar com diferentes pensamentos de forma crítica que tornam Vigotski um revolucionário no estudo do desenvolvimento humano".

A visão desse teórico sobre o desenvolvimento humano se dá a partir das perspectivas em contexto cultural, social e histórico, sem desconsiderar, contudo, o individual e o coletivo, enquanto construção do sujeito em desenvolvimento para a Psicologia como um todo. Nesse sentido, o desenvolvimento é constantemente influenciado por processos culturais que se entrelaçam aos processos biológicos e hereditários. Assim, o ser humano se constitui e se desenvolve no e pelos processos históricos, Dias (2014, p. 28).

Ao discorrer a respeito dos processos que envolvem a perspectiva histórico-cultural do desenvolvimento humano, Lopes de Oliveira (2006, p. 15) afirma que "a cultura não é um sistema estático, mas em constante transformação, um sistema semiótico que se expressa, consolida e modifica no contexto concreto das práticas sociais".

$\mathrm{Na}$ relação sujeito-cultura-contexto acontecem as trocas recíprocas, assim como, múltiplas produções de significados e afetos, construção e reconstrução interna e externa de conhecimentos e experiências compartilhadas, a partir de procedimentos dialógicos de negociação com o outro, numa reação infinitamente diversa e permeada de diálogo (Santana \& Lopes de Oliveira, 2016, p. 19). Nesse sentido, sujeito e contextos não podem ser considerados isoladamente ou de forma abstrata.

A constituição do sujeito enquanto tal se dá mediante a interação dos sentidos internos e externos expressos através de signos, afetividade, relações sociais 
historicamente construídas. Assim, o decurso de sua existência é formado subjetivamente, constituindo-se assim, as singularidades (Alves \& Pedroza, 2016, p. 42).

A respeito da constituição entre o eu e o outro, Bakhtin, cuja obra converge em vários sentidos com Vigotski considera tal movimento como princípio da alteridade, ponto de destaque nos seus escritos, nos quais considera como o espaço no qual as individualidades se compõem. Nessa direção, esclarece que

é sempre o outro que dá ao eu uma completude provisória e necessária, fornece elementos que o encorpam e que o fazem ser 0 que é. No corpo biológico que somos constituímos histórica e geograficamente o sujeito que seremos - não sempre o mesmo, segundo suas relações incompleto e inconcluso (Freitas, 2013, p. 12-13).

Para Bakhtin o outro é um ser além de vivo, falante, e no processo de construção de sua identidade produz signos e significados na sua relação com o outro e nela se configura a educação enquanto tal. $\mathrm{E}$ a partir desse encontro nenhum dos envolvidos sai da mesma maneira que entrou, numa relação de aprendizagem mútua, mediante as palavras de ambos, sem necessariamente haver consenso nas ideias e palavras, mas uma relação de troca, dialógica, criativa e produtiva, construtiva.

Se não há signo sem ideologia, não há diálogo efetivo sem os necessários deslocamentos, ainda que mínimos de uma posição para compreender outra posição, e dela retornar para sua posição enriquecido pelo embate produtivo do encontro de consciências equipolentes autônomas, mas não, independentes das condições sócio-históricas de suas constituições. Sem esses deslocamentos, o diálogo morre no seu nascedouro: são vozes mudas que falam a surdos. (Freitas, 2013, p. 15-16).

Para Bakhtin, o diálogo com o outro permite algo como um jogo de contra palavras, possibilitando assim a escuta, o surgimento/ressurgimento de signos e sentidos plurivocais, da compreensão responsável, aproximações/reaproximações, conhecimento/reconhecimento, mas que assegure sempre, irrestritamente a voz do outro, como efeito das estruturas socialmente construídas, compostos de cultura na qual perpassam pessoas, tempos, espaços, luzes, arte, vida, histórias (Freitas, 2013). 
O pensamento filosófico de Vigotski e o Bakhtin foram orientados pelo materialismohistórico proposto por Karl Marx. Por essa razão, desenvolveram estudos voltados para assuntos sobre a consciência, formação da linguagem e do pensamento ideológico concreto, fundamentados em áreas como a Psicologia, ciência da arte e da literatura, a filosofia da linguagem, a semiótica, entre outras. Ao discorrer sobre as contribuições dos teóricos acima citados, Zuin (2010, p. 36) escreve:

A questão dos objetos tratados por eles como a relação individual e o social, o signo e a ideologia vai além em cada um dos seus campos de estudos, pois os dois autores afirmavam a necessidade de um enfoque materialista-dialético na psicologia e na linguística, a fim de poder compreender a natureza histórico-social dos fundamentais processos psíquicos humanos.

O materialismo-dialético se fundamenta no entendimento do signo como principal mediador dos processos psíquicos no indivíduo e só é concebido mediante a interação social. Nessa perspectiva, Bakhtin amplia esse fundamento ao acrescentar que o signo é ideológico, ou em outras palavras, toda ideologia é um signo (Freitas, 2013, p.37). Sem signo não há ideologia.

Vigotski por sua vez, enfatiza a importância dos signos nas funções psíquicas humanas. É através deles que o indivíduo concebe, constrói e perpetua a cultura adquirida socialmente, mediados que são pela linguagem. Dessa forma, os processos mediacionais intencionais ou não, permitem o desenvolvimento das chamadas funções superiores, as quais compõem ou relacionam pensamento e linguagem que atuam como instrumentos sociais concretos e de constituição do sujeito. Por esse motivo, os signos atuam não apenas como transmissores de significados, mas passam à relevância de instrumentos de significação físicos e simbólicos, posto que as experiências individuais e os processos mentais vão se constituindo.

A mediação por meio de instrumentos aplicados ao trabalho compõe o pensamento filosófico de Marx. Já Bakhtin e Vigotski propõem a mediação a partir da construção de signos, imagem, palavra, gesto e instrumentos. Tendo em vista que as necessidades humanas vão se complexificando no decurso da vida humana, novas formas mediacionais são exigidas. A mediação funciona assim, como um propulsor, catalisador e configurador dos modos de constituição humana.

Quando se refere aos processos ideológicos de constituição do humano, Marx justifica que esse processo nada mais é do que "a tentativa do homem de explicar as coisas 
através das ideias" (Zuin, 2010, p. 41). As formas de expressão e produção utilizadas para a explicação dos fenômenos parte de fatos reais tais como: os costumes, os valores, a política, a religião, a produção intelectual, todos construídos por meio da linguagem dos signos.

O signo carrega em si valor social no qual o indivíduo está envolvido. Abarca, da mesma forma, elementos advindos do mundo interior e exterior, em outras palavras, tanto do universo psíquico como ideológico. A consciência, assim como os signos também está carregada de material ideológico, as quais podem ser compreendidas em espaços temporais e flexíveis.

Outro ponto de importante destaque na concepção do materialismo histórico diz respeito ao uso da palavra como instrumento de relação social de domínio de todos. É, pois, considerada um elemento neutro e independe dos significados a ela atribuídos. Permite também a compreensão e interpretação dos atos humanos. Cada palavra possui sentido e significado construído seja através do senso e ou do dissenso entre os envolvidos. É também, conforme afirma Bakhtin (1995) "o modo mais puro e sensível da relação social", (p.36).

Diante do exposto, pode-se inferir que o desenvolvimento humano depende tanto da perspectiva histórica quanto do contexto no qual o indivíduo é inserido mesmo antes do nascimento. Cada desenvolvimento possui, entretanto, características e condições próprias, definidas no tempo e espaço vivenciados, influenciando e sendo influenciado. Não apenas respondem ao ambiente, assim como interage e com ele sofre modificações constantes.

Podemos dizer também que o desenvolvimento é multidimensional e multidirecional, afirmam Papalia, Olds e Feldman (2006, p. 49). Envolve necessariamente equilíbrio entre crescimento e declínio, ganhos e perdas em vários sentidos experimentados pelo indivíduo durante o seu ciclo de vida nos aspectos físico, cognitivo e psicossocial, interligados uns aos outros.

\section{Métodos de pesquisa em Psicologia do Desenvolvimento}

Conforme já mostramos nesse trabalho, desde os primórdios até a época atual a Psicologia do Desenvolvimento utiliza-se de métodos e técnicas científicas que mostram a validade e confiabilidade dos estudos realizados e que tornaram possível seu estabelecimento enquanto ciência. A observação e a experimentação têm sido os métodos mais comuns em estudos seja com crianças, adolescentes ou adultos. Tal rigor se faz necessário a fim e que os dados levantados gerem consistência e sejam passíveis de 
replicação de acordo com os objetivos propostos. Schaffer (2009) ao descrever alguns dos principais métodos e recursos utilizados no levantamento de informações na pesquisa em psicologia do desenvolvimento aponta métodos como: etnografia, estudo de caso, psicofisiológicos, as observações e o método transversal os quais descrevemos brevemente a seguir.

O método etnográfico, faz parte dos instrumentos, utilizado em sua maioria por Antropólogos, consiste na descrição, a partir de anotações, observação, conversas, por parte do pesquisador, aplicado em contextos culturais e subculturais, para então estruturar os dados compilados e valores que permitam calcular ou analisar os impactos que causam no desenvolvimento dos envolvidos.

O estudo de caso, realizado mediante um mergulho mais profundo no objeto de estudo, faz uso de entrevistas, observações cuidadosas e pontuais, informações fidedignas dos envolvidos, sejam eles pais, responsáveis, professores, entre outros, a fim de que se estabeleça possibilidades a partir das informações colhidas.

Os métodos psicofisiológicos, baseiam-se na medição ou relação que abarquem informações fisiológicas e comportamentais. Servem para dar esclarecimento e interpretação de dados perceptivos, cognitivos ou emocionais dos envolvidos. É importante destacar, que em qualquer dos métodos que envolvam observações, as mesmas podem ser naturalistas, quando são feitas no ambiente natural do objeto de pesquisa ou estruturadas, seja em laboratórios, por exemplo, quando o objeto recebe estímulos de acordo com o objetivo do estudo.

As observações também podem ocorrer com base em três modelos de estudos: longitudinal, transversal e sequencial. No longitudinal são aplicados repetidamente ferramentas próprias, durante períodos mais longos, envolvendo geralmente um mesmo participante, à medida em que avançam no seu ciclo ou fases da vida. Esse modelo de pesquisa tem por desvantagem a possibilidade de causar tanto o efeito da prática, assim como o desgaste do objeto pesquisado, o que pode resultar em dados que não tenham representatividade nas amostras colhidas. (Schaffer, 2009, p. 33).

O modelo transversal é justamente o oposto do longitudinal, pois são estudos que demandam um período menor de estudos empregados e é mais comumente utilizado por pesquisadores. Permite a comparação de grupos de faixas etárias distintas, mas pode ocorrer prejuízo por não permitir o acompanhamento do desenvolvimento e, se não for aplicado corretamente, pode gerar dados equivocados e não mostrar a realidade levantada.

Por fim, o modelo sequencial oferece uma combinação dos modelos longitudinal e transversal, com a vantagem de permitir discriminações detalhadas de possíveis tendências do desenvolvimento, ao invés do chamado, efeito cortes. 


\section{A Psicologia do Desenvolvimento e a Educação}

Dessen e Costa Júnior (2005), chamam a atenção para a importância que a ciência do desenvolvimento tem para a educação, pois, dessa forma, contribuem para que se repense os processos de ensino, métodos e teorias aplicados no aprender, o qual implica nas múltiplas atividades que influenciam a evolução do indivíduo, permeada por processos fisiológicos, culturais, afetivos e sociais em diferentes aspectos e dimensões.

\section{Desenvolvimento Humano e Adolescência}

A vida em sociedade obedece a movimentos constantes no seu processo de desenvolvimento. O mesmo acontece com a concepção de adolescência, que não pode ser compreendida senão como um processo de subjetivação com tempo e espaço históricos próprios, socialmente construídos. Nesse sentido, se torna um processo complexo, podendo representar um "momento de passagem da família ao socius" (Coutinho, 2009, p. 12). Por isso, "desde a Modernidade, o adolescente, sozinho ou em grupo, direta ou indiretamente, coloca questões sobre o seu estatuto e sua situação, que atravessam e ultrapassam o seu caso individual" na sua origem histórica e social, perpassado por registros psíquicos, familiar, político, institucional e espaços públicos, nos quais se constitui.

A adolescência, então, tem sua explicação na subjetividade (aspectos psicológicos) e sociais e nesse sentido, varia de acordo com o contexto sociocultural de um povo, a partir do qual o indivíduo insere-se no 'laço social' mediante as prerrogativas do meio de vivência e as intencionalidades individuais. Assim, a adolescência pode ser compreendida, no mundo ocidental, como um fato cultural, o que a torna um fenômeno estudado de forma híbrida por diferentes áreas do conhecimento (antropologia, psicologia, biologia, sociologia, história, entre outros).

Em algumas culturas, aplicam-se os 'rituais pubertários' ou 'rituais de iniciação', no qual o adolescente é submetido a situações de caráter coletivo imposto pelo grupo no qual irá conviver (Coutinho, 2009; Papalia, Olds \& Feldman, 2006). Outras culturas promovem cerimônias com ritos próprios. Para outras, significa o afastamento, aos poucos, dos laços familiares (pai, mãe e comunidade), para assumir sua própria identidade.

Nos diversos grupos e locais que envolvem a vida do adolescente, a escola também ocupa local de contexto para a troca de conhecimentos e cultura coletiva, pois a interação que antes ocupava a vizinhança cresce e adquire novas formas de expressão provocada pelo contato, cada vez maior e mais interativo com os pares de convivência. 


\section{Construção histórica de Adolescência}

O conceito de adolescência começou a aparecer na civilização ocidental em meados de 1850, ocasião na qual passou inclusive a ganhar definição em dicionários vigentes àquela época, vindo a consolidar-se no século XX. É uma palavra de origem latina, 'adulescens' ou 'adolesens', originada do verbo 'adolescere' (crescer). No francês antigo (século XIII), adolescente era substantivo masculino, passando a designar também o gênero feminino, no século XV. Na Antiguidade romana, 'adulescens', significava o período de iniciação do jovem em atividades civis e militares específicas, com conotação sociopolítica (Coutinho, 2009).

O termo puberdade vem do latim 'pubertas', cuja derivação é púbis, pelo e seu sentido original conserva-se até os dias atuais. Essa definição remete justamente às modificações tanto corporais quanto fisiológicas e que marcam assim, o término do período da infância. A adolescência, entretanto, refere-se às transformações para além da fisiologia, pois marcado por aspectos psicológicos e sociais, referindo-se a

um contexto sociocultural individualista, onde a cada indivíduo é dada a responsabilidade de administrar seu próprio destino, inserindo-se no laço social da maneira que the for preferível ou possível. Nesse sentido, consideramos que a adolescência é um fato cultural, uma vez que o modo como cada sociedade lida com seus jovens é particular e articulado a todo o seu contexto sociocultural e histórico. (Coutinho, 2009, p. 19).

A partir do século $X X$, o fenômeno da adolescência adquire grande importância antropológica ocidental apoiado em pesquisas sobre as civilizações, seus comportamentos, culturas, usos e costumes, vindos desde o século XVI. A grande descoberta foi no sentido de perceber que o entendimento da adolescência para o mundo moderno não é universal ou específico, nem mesmo na vida cronológica humana, mas baseia-se em contextos culturais diversificados ou nem mesmo existem tal como entendido no mundo ocidental.

Da mesma forma, percebeu-se em outras culturas, os rituais de passagem de caráter essencialmente coletivo e podiam durar períodos curtos com realização de cerimônias que, em alguns casos se estendiam por um período maior e não representavam uma condição do mundo da infância para a adolescência, mas dizia respeito à simbologia de "entrada no mundo da sexualidade genital, o que implica separação da mãe e aquisição de uma nova identidade" (Coutinho, 2009, p. 21), ligados à "origem do grupo social". Esses 
rituais envolviam provas físicas, festas, tatuagens, agressões e até mesmo cerimônias de circuncisão.

Passados os rituais, os adolescentes abandonavam a convivência familiar com os pais para unir-se aos mais velhos ou separados das mulheres. Tinham ainda que provar virilidade através de provas físicas e relacionamentos homossexuais temporários para fortalecer sua fertilidade.

Van Gennep, autor da obra Os rituais de passagem (1909-1981), distingue esses ritos em três fases: fase da separação no qual o indivíduo é afastado da família a fim de se preparar para a iniciação. Tinham o corpo marcado com tatuagens que mostrava o pertencimento a determinado grupo. Fase da margem, onde a aplicação de prova era considerada como um período de sofrimento aos quais era submetido com vistas ao aprendizado de saberes, como o ensino de nova língua, danças, valorizado pela comunidade ao qual deveria ser inserido, com a obrigação, entretanto, de, naquele momento, manter em segredo as atividades pelas quais passada. Por último, a fase da agregação era o momento no qual ao indivíduo era conferido o estatuto social e que lhe permitia acesso a uma determinada divindade, até então não conhecida.

A diferença de iniciação imposta às mulheres é que o ritual feminino observava saberes voltados para a sexualidade, maternidade e obrigações como esposa. Os rituais, no entanto, sejam para homens ou para mulheres apontava necessariamente para os laços sociais na qual aquela comunidade se sustenta. A adolescência pode ser vista assim, como parte da cultura (Chaves, 2013, p. 35).

Se na cultura ocidental a adolescência tem uma conotação crítica e de caráter individualista, em outras culturas, no entanto, além de não terem denominação nesses termos, tem um caráter de transição ou de passagem, no qual se realizam as cerimônias ou rituais coletivos de iniciação como principal marca. Gutierra (2003, p. 29) diz que: "Até mesmo nas sociedades ditas primitivas, os ritos de passagem imergiam o jovem num banho simbólico que significava transformações físicas e a transição da vida infantil para a adulta".

As relações do indivíduo adolescente com o seu meio não obedecem a padrões lineares de desenvolvimento, ao contrário, apresenta por vezes momentos de tensão tanto com relação à vida particular quanto com a vida coletiva, entre o que é fruto da subjetividade e o que é objetivo.

A subjetividade do adolescente é construída a partir dos processos de interiorização da cultura socialmente constituída. A sua singularidade, entretanto, se distingue do social. $O$ seu reconhecimento enquanto sujeito permite o desenvolvimento do reconhecimento pessoal, autônomo e não apenas um reprodutor da cultura recebida (Chaves, 2013, p. 35). 


\section{A adolescência no Brasil}

A Constituição Federativa do Brasil de 1988 é considerada uma legislação inovadora no que diz respeito aos direitos de crianças e adolescentes, independentemente de qualquer situação socioeconômica, gênero ou expressão sexual, raça e etnia, religião, local de nascimento, deficiência, moradia, entre outros.

A partir do reconhecimento de crianças e adolescentes como sujeitos de direitos a Constituição Federal (CF), determina sua proteção sob a responsabilidade do Poder Público, da Sociedade, da Comunidade Imediata e da família, com prioridade na destinação dos recursos públicos, assim como são considerados em situação especial de desenvolvimento.

De acordo com o Estatuto da criança e do Adolescente (ECA) instituído pela Lei no 8.069 de 13 de julho de 1990, no Brasil, considera-se criança a pessoa até doze anos de idade incompletos, e adolescentes os indivíduos entre treze e dezoito anos de idade. Já "Os organismos internacionais, os estudos demográficos, os Censos, o IPEA e o Instituto de Cidadania, por sua vez, consideram jovens as pessoas entre 15-24 anos, mas essa faixa é bastante variável nos países ibero-americanos, podendo ir até 35 anos" (Chaves, 2013, p. 35).

Entretanto, discute-se que o desenvolvimento de políticas públicas envolvendo crianças e adolescentes brasileiros devem ser estendidos para além das determinações protetivas e que abranjam na sua totalidade as relações do sujeito em seus diferentes contextos, que inclui desafios e expectativas.

A adolescência vista como um processo de transição no desenvolvimento pode se estender por mais de uma década. Com o propósito de contribuir com as concepções de adolescência, Papalia (2000) mostra que não há uma definição real e concreta sobre o início ou fim, mas considera-se, entretanto, o início da puberdade, período que leva à maturidade sexual ou fertilidade e capacidade de reprodução.

Antes do século $\mathrm{XX}$, especificamente nas culturas ocidentais as crianças eram inseridas no mundo dos adultos na medida em que amadureciam nos aspectos físicos ou quando mostravam capacidade para desenvolver produção material, ou seja, quando já podiam trabalhar com os pais. Com o passar dos tempos e na atualidade esse ingresso tornou-se mais tardio, possibilitando inclusive imersão no universo escolar antes de qualquer definição de produção material.

Aos adolescentes americanos é permitido o ingresso na vida adulta mediante definições legais, aos 17 anos, no qual é permitido o alistamento nas forças armadas. 
Sendo que aos 18 pode constituir família sem autorização parental e em outros casos, entre 18 e 21 anos podem contrair contratos.

Cabe destacar aqui também a definição sociológica de imersão na vida adulta, que ocorre a partir da percepção pessoal de autossuficiência, qual seja escolha profissional, "estabelecimento de vínculo significativo ou constituição familiar" (Papalia, 2000, p. 310). Sobre a definição psicológica, observa-se a maturidade cognitiva e a capacidade de compreender funções abstratas que leva ao desenvolvimento da maturidade emocional a partir de realizações do descobrimento da própria identidade, independência familiar, descoberta de valores e ampliação dos relacionamentos sociais.

\section{A adolescência e a formação da identidade}

O processo de construção de identidade permeia todo o período da adolescência, período no qual busca desenvolver aspectos psicossociais que poderão definir os papéis que virá a desempenhar na sociedade. Nesse sentido, envida esforços na busca por afirmação e organização de habilidades, necessidades, interesses e aspirações que são doravante expressados no seu contexto social.

Ao discorrer sobre o desenvolvimento da identidade adolescente Schaffer (2009) frisa que esse processo é influenciado por pelo menos quatro fatores: crescimento cognitivo - que corresponde ao domínio do pensamento operacional formal, lógico amparados por circunstâncias hipotéticas possibilitando assim a projeção de identidades promissoras com ou sem seus pares da mesma idade.

As Influências parentais - ocorrem a partir das relações com os pais, visto que é onde observam inicialmente a identificação consanguínea ou forma de criação, com forte influência no desenvolvimento ou não de uma identidade saudável e com capacidade de adaptação durante a adolescência.

Nesse ponto enfatizamos que a família, vista como um organismo dinâmico e em constante movimento considera que "cada membro familiar é um indivíduo em desenvolvimento e que o relacionamento entre marido e mulher, pai e filho e entre irmãos muda de modos que podem influenciar o desenvolvimento de cada membro familiar" (Schaffer, 2009, p. 505). Assim, complementa, "a família não é apenas um sistema no qual acontecem mudanças de desenvolvimento, sua dinâmica também muda com o desenvolvimento de seus membros" (p.539).

Outro fator importante são as Influências Escolares - a escola é considerada um local de troca de informações sistematizadas privilegiadas e nesse sentido, exerce 
influências que permitem ao adolescente confrontar ideias, conviver com a diversidade em vários sentidos, por e contrapor expectativas e a construir pontos de vista distintos em diferentes áreas do conhecimento. A respeito da influência escolar Guimarães (2012) pondera que a escola é um espaço privilegiado e útil na construção de identidades, assim como de projetos de vida, oportunidade de aprendizagem e desenvolvimento da autonomia.

Por fim, as Influências culturais - o contexto sociocultural no qual se desenvolve a construção da identidade opera no sentido histórico, através do qual pode explorar opções com peculiaridades próprias a partir do qual se busca a resposta para questões sobre 'quem sou' naquele contexto. A resposta à essa questão por vezes, é desafiadora para a adolescência. Importante dizer, entretanto, que o processo de construção da identidade é irregular e continuo, e prossegue na idade adulta (Guimarães 2012, p. 453).

$\mathrm{Na}$ abordagem sobre o desenvolvimento da identidade e do sentido de vida na adolescência, Rodriguez e Damásio (2014) ponderam que o processo de constituição da identidade tem como ponto de partida a concepção que o adolescente tem de si mesmo o qual abarca aspectos sociais, de interações e as próprias características individuais. Tais concepções influem na forma como se estabelece os propósitos orientados para o futuro.

Dessa forma, ao passar por diferentes experiências no seu processo de desenvolvimento humano em constante interação com o seu contexto sociofamiliar, o indivíduo está, na verdade, desejando encontrar seu lugar no mundo permeado por crenças, valores, ao mesmo tempo em que vivencia mudanças físicas, psicológicas e sociais.

A chegada da adolescência pode significar um período de grande tensão nesse ciclo de vida. Ao mesmo tempo em que se apresentam possibilidades de desenvolvimento, pode representar riscos principalmente pela dificuldade de lidar com as transformações físicas, mentais e sociais decorrentes das modificações pelas quais passa (Papalia, 2006).

Afora esses riscos, temos que a identidade não é algo fixo, imóvel ou imutável, mas é marcada por continuidades, descontinuidades, semelhanças e diferenças, situações semelhantes ou antagonismos, transformações, aproximação e distanciamento do contexto. O sujeito é ao mesmo tempo, "muitas coisas", carrega identidades diversas, permeadas na classe social, religião, nacionalidade, gênero, etnia, gostos e valores, mesclas, multiplicidade. "As identidades dos jovens são marcadas pelos espaços que frequentam, pelo lugar onde vivem, pelo contato com outros jovens. Modificam-se ao longo do tempo, incorporam novos elementos, enfim, movimentam-se" (Guimarães, 2012, p. 84).

Chaves (2013, p. 45) chama a atenção para as representações ideológicas da adolescência construídas ao longo da própria história e fatos que envolvem as concepções apresentadas e a crença de que a adolescência é uma fase crítica, conturbada no que diz 
respeito à sexualidade, a ênfase na puberdade e suas transformações físicas e reprodutivas, sendo que na verdade o que deve ser considerado é o fato de que são as questões objetivas e não subjetivas que marcam tanto as transformações biológicas como psíquicas e não devem ser vistas como um problema, sem observar que "no decorrer do tempo e em distintas culturas, as aquisições corporais assumem valorações díspares, que levam o indivíduo a se relacionar diferentemente consigo mesmo e com o mundo (Kahhale, citado por Chaves, 2013).

A afirmação da adolescência como modo de vida, desenvolvimento fisiopsicológico, crescimento e mudanças sociais, além da crença em ideias rasas, com ênfase na trajetória entre a vida infantil e fase adulta, aquisição de experiências diferenciadas novas, também são consideradas como representações superficiais da adolescência.

$\mathrm{Na}$ concepção desse autor, trata-se de um saber limitado e estereotipado sobre a adolescência e juventude, distante, ligado ao "imediato presente" que apontam para "transformações gerais", fruto de uma "sociedade despreparada", onde os comportamentos carecem de explicação, "tratando esse estágio como um processo, um percurso, uma passagem, um túnel escuro que levará da etapa anterior (infância) à posterior (maturidade) (p. 46).

Por fim, pondera que tais representações corroboram com a violência contra a adolescência por parte dos adultos, e ao entendimento equivocado, cujos comportamentos reportam à uma fase de temores, risco a doenças sexualmente transmissíveis, à escolha profissional, fase reprodutiva, responsabilização pelos atos proferidos, exigências socioeconômicas. Essas representações geram prejuízo à subjetividade, incompreensão e naturalização indistinta e homogênea do ser adolescente na contemporaneidade ocidental.

Nesse ponto de vista, Coutinho (2009) levanta a hipótese de que a organização da vida em sociedade é o reflexo do modo como os adultos tratam os seus jovens e é desse fato que originou a construção social da adolescência, influenciada pelas transformações socioeconômicas advindas nos séculos XVIII e XIX, considerando a adolescência como um ideal cultural (p. 53, 55, respectivamente).

A adolescência, portanto, é um fenômeno que indica pluralidade e por isso mesmo considerado adolescências, que ocorre em conjunto com os fenômenos sociais, tempo histórico e são definidas de acordo com aspectos de cada época ou processos de desenvolvimento humano, que é por si mesmo dinâmico, sistemático e progressivo.

O processo de construção do 'eu', que constitui o conceito de si mesmo, e, posteriormente, a definição de papéis pelo adolescente passa por diversos contextos, os quais fornecem ferramentas que atendam ou não às expectativas dos demais, sejam pais, professores ou pessoas do seu círculo social. Entretanto, o autoconceito - o eu real, e o eu 
ideal - que é aquilo que se gostaria de ser, depende, em grande medida, do grau de maturidade cognitiva e ao mesmo tempo, psicológica, representando "maior discrepância entre a imagem do eu ideal a que o sujeito aspira e a realidade das falhas e limitações que encontra em seu eu real" (Oliva, 2004, p. 337).

Conclui-se então, que o conceito de si mesmo tende a se multiplicar e pode se diversificar no período que antecede à adolescência, fenômeno que afeta a autoestima e varia de acordo com diferentes aspectos, entre eles, o físico, acadêmico, social e entre seus parentes e iguais. As relações afetivo-sexuais, assim como a profissionalização também são aspectos que movimentam e adquirem grande importância nos processos de construção adolescente, tão necessários no ciclo vital de desenvolvimento humano.

\section{Adolescência e Socioeducação}

A Declaração Universal dos direitos do homem é considerada o documento propulsor da proteção aos diretos naturais do homem e ocorreu na França em 1789, ocasião na qual representantes da comunidade francesa reuniram-se em Assembleia Nacional. Entre os princípios elencados estão o reconhecimento de que o homem nasce livre e com igualdade de direitos, sem predominância de poderio de um homem sobe 0 outro a não ser por imanente condição expressa de maneira a que ambos gozem de todas as prerrogativas de manutenção de igual direito, tendo a lei como expressão da vontade geral (Botelho \& Schwarcz, 2012; Ferreira, 2010; Guerra, Kind, Afonso \& Prado, 2012; Lago, Mozzer \& Santibanez, 2013; Schilling, 2014).

De acordo com os dados do último Censo Demográfico divulgado em 2010 pelo Instituto Brasileiro de Geografia e Estatística (IBGE), estima-se que a população de crianças e adolescentes seja de aproximadamente 6 milhões.

O Brasil, em se tratando de proteção aos direitos da infância e da juventude é signatário da Declaração Universal dos Direitos da Pessoa Humana, referendado pela ONU em 1948. Princípios como o reconhecimento da igualdade de direitos e dignidade humana, lazer, saúde e bem-estar familiar, cuidados e assistência especiais à infância, educação, orientação profissional, liberdade de crença, expressão cultural, são alguns dos direitos assegurados.

A Declaração dos Direitos da Criança surgiu em 1959, e adotada pela Assembleia Geral das Nações Unidas, reconhece a criança como beneficiária de proteção e cuidados especiais antes e após o seu nascimento, em virtude de imaturidade física e mental. Já em 
novembro de 1989 em nova Assembleia, adotou-se a Convenção dos Direitos da Criança e do Adolescente.

Outras normativas orientam o Sistema de Atendimento Socioeducativo Brasileiro, a saber, Convenção da ONU (Organização das Nações Unidas) sobre os Direitos da Criança, Sistema Global e Sistema Interamericano dos Direitos Humanos: Regras Mínimas das Nações Unidas para Administração da Justiça Juvenil - Regras Mínimas de Beijing Regras Mínimas das Nações Unidas para Proteção dos Jovens Privados de Liberdade. De todas os Brasil é signatário.

Três doutrinas básicas versam sobre o Direito do Menor na história de proteção aos direitos de crianças e adolescentes. A primeira delas é a Doutrina da Proteção Integral, preconizada pela ONU, com vistas à garantia de atendimento de necessidades das pessoas menor de idade, no que concerne à saúde, educação, lazer/recreação, profissionalização, entre outras.

A segunda é conhecida como Doutrina de Direito Penal do Menor, aplicada somente se o menor viesse a cometer algum ato de delinquência juvenil, e a terceira, Doutrina Intermediária da Situação Irregular. Nessa Doutrina, entretanto, a criança e adolescente não gozavam dos direitos concernentes à sua condição peculiar de desenvolvimento como sujeito de direitos civis, humanos e sociais apontado na CF - artigo 227, §3º, inciso V e no ECA (artigos $3^{\circ} 6 .^{\circ}$ e $15^{\circ}$ ).

A Doutrina da Situação Irregular considera como sujeito de direitos, menores em estado de patologia social, desde que definida legalmente. Graças à Convenção dos Direitos da Criança de 1989, a doutrina vigente no Brasil é a da Proteção Integral, incorporada à CF e ao ECA, complementado por outras normas - Sistema Único de Saúde, Lei de Diretrizes e Bases da Educação e até dispositivos do Código do Consumidor vigente.

Os atos considerados delituosos por parte de qualquer adolescente são julgados igualmente na forma da lei, com direito a ampla defesa. Assegura-se também a livre expressão de ideias e opinião, crença religiosa, entre outros. Nesse sentido, nascem também as discussões e conceitos sobre os direitos humanos. Tal luta, na verdade, preconiza a construção da igualdade de direitos, "convívio entre iguais e em sociedade, mas também a um exercício de diferenças, e de diferenças entre iguais" (Botelho \& Schwarcz, 2012). 


\section{O Marco Legal do Sistema Socioeducativo}

Corroborando a Doutrina da Proteção Integral, preconizada no artigo 227 da Constituição Federativa do Brasil, de 1988, o Estatuto da Criança e do Adolescente, instituído pela Lei no 8.069/90, é considerado um avanço, em relação à Declaração Universal dos Direitos do Homem (1948), a Declaração dos Direitos da Criança (1958) e, mais tarde, a Convenção dos Direitos da Criança (1989), contrapondo-se ao Código de Menores - Lei n. 6.697/1979, oportunizando assim, a inclusão social de adolescentes em situação de conflito com a lei. Nesse sentido, podemos dizer que, crianças e adolescentes brasileiros têm, legalmente, seus direitos garantidos.

O ECA estabelece como adolescência, a fase que compreende os 12 aos 18 anos (incompletos) de idade. A partir de então, os direitos especificados na referida lei, Ihe conferem, entre outras coisas, oportunidades e facilidades legais, a fim de que tenha acesso ao pleno desenvolvimento físico, mental, moral, espiritual e social, em condições dignas e com liberdade, sem prejuízo, de espécie alguma, da proteção integral como pessoa humana. No Brasil, o sistema de garantia de direitos envolve os seguintes subsistemas: Sistema único de Saúde (SUS), o Sistema Único de Assistência Social (SUAS) e o Sistema Nacional de Atendimento Socioeducativo (SINASE), podemos acrescentar ainda, o Sistema Educacional e o Sistema de Justiça.

O Sistema Nacional de Atendimento Socioeducativo (SINASE), foi instituído pela Resolução no 119/2006 pelo Conselho Nacional dos Direitos da Criança e do Adolescente (CONANDA), e regulamentado pela Lei ำ12.594/2012, cujo objetivo precípuo é a ordenação e sistematização do atendimento exclusivo de adolescente autor de ato infracional, já sentenciado ou em aguardo de apuração do ato cometido. Estando acautelado pelo Estado, é obrigação do Governo, prover-lhe atenção quanto à saúde, ao sistema de justiça, assistência social, proteção social e segurança (Paiva, Souza \& Rodrigues, 2014).

Atendendo ao princípio da incompletude institucional do SINASE, devem-se firmar parcerias com o maior número possível de serviços, profissionais e equipamentos públicos existentes na comunidade, para a consecução dos objetivos apontados na referida Lei. A escola é um desses recursos, e nela devem ser matriculados todos os adolescentes em cumprimento de medida socioeducativa, a fim de que deem continuidade à vida acadêmica, com a obrigatoriedade de frequentar as aulas e obter menção global satisfatória, nos processos relacionados aos conhecimentos, habilidades, valores e atitudes. 


\section{O Sistema de Medidas Socioeducativas, a adolescência e a violência na escola}

O SINASE, considerado como "um conjunto ordenado de princípios, regras e critérios, de caráter jurídico, político, pedagógico, financeiro e administrativo, que envolve o processo de apuração de ato infracional até a execução de medida socioeducativa" (Brasil, 2006), inclui o sistema estadual, municipal e distrital, bem como suas políticas, planos e programas, estabelecidos dentro do Sistema da Garantia de Direitos (SGD), que abrange o Sistema Educacional, o Sistema de Justiça, e Segurança Pública, o Sistema Único de Saúde - SUS, e o Sistema Único de Assistência Social (SUAS).

A inclusão do Sistema Educacional à Socioeducação mostra a prevalência da ação socioeducativa sobre os aspectos meramente sancionatórios ou punitivos. A aplicação das medidas socioeducativas previstas e regulamentadas pelo ECA deve acontecer da seguinte forma: advertência, reparação de dano, prestação de serviços à comunidade (PSC), liberdade assistida (LA), semiliberdade (semi) e a internação. Pode ocorrer também a cumulação de mediadas protetivas e até a combinação de mais de uma medida (artigos 112 e 113). Conforme dissemos anteriormente, essas medidas observam as proposições da legislação das Nações Unidas, que foi adotada pela CF (artigo 227), Convenção dos Direitos da Criança e Adolescência, Regras de Beijing e as Regras Mínimas das Nações Unidas no que diz respeito a Proteção dos jovens Privados de Liberdade. De acordo com Ferreira (2010, p. 120):

levar-se-ão em conta as necessidades pedagógicas, preferindo aquelas que visem ao fortalecimento dos vínculos familiares e comunitários (ECA, art. 113, c.c. arts. 99 e 100); além de sua capacidade de cumpri-la, as circunstâncias e a gravidade da infração (ECA, art. 112, $\left.\S 1^{\circ}\right)$.

A Liberdade Assistida, inicialmente, não pressupõe o cerceamento do direito adolescente, ainda que o mesmo tenha que receber do órgão de acompanhamento, as orientações e fornecer informações sobre sua vida e a situação familiar, tanto que deve estar na companhia de pai/mãe ou responsável legal. Cabe ao seu orientador, no caso do Distrito Federal, as Unidades de Acompanhamento das Medidas Socioeducativas UAMAS, zelar pela escolarização, profissionalização e inserção no mercado de trabalho. Entretanto, o adolescente é livre para ingressar no mundo do trabalho, mas precisa estar matriculado em uma Unidade do Ensino Fundamental, observa Ferreira, (2010). 
Muito se discute no Brasil sobre a validade ou em certo sentido, a eficácia das medidas socioeducativas aplicadas aos adolescentes, principalmente se 0 ato infracional envolver atentado à vida e à dignidade do próximo. A sanção aplicada nesses casos envolve a internação em entidades de atendimento.

$\mathrm{Na}$ verdade o que percebe é a inexistência de informações claras e precisas do que de fato seja a socioeducação e como funciona, de quem é a responsabilidade pela manutenção das Entidades de Atendimento - governamentais e não-governamentais, planejamento e execução de programas de proteção e socioeducativos seja qual for o regime aplicado: orientação e apoio sociofamiliar; apoio socioeducativo em meio aberto; colocação familiar; acolhimento institucional; prestação de serviços à comunidade; liberdade assistida; semiliberdade; e internação. É o que detalha o artigo 90, incisos I-VIII.

A escolarização é um direito fundamental do adolescente em cumprimento de medida socioeducativa seja ela qual for. Entretanto, observam Yokoy de Souza e Lopes de Oliveira (2012, p. 291): "a conjugação entre reparação do dano, promoção de desenvolvimento, educação escolar e profissionalização, objetivos que estão no cerne do atendimento aos jovens autores de ato infracional, envolve uma relação complexa e nem sempre bem-sucedida".

Além do cumprimento à garantia de educação (CF, artigo 205 e ECA, artigo 214), é incentivado também pela legislação o acesso à educação informal, cultura, artes, esporte e lazer, sendo que essas atividades são consideradas como essenciais para a efetivação do desenvolvimento cultural e de participação comunitária cidadã (Yokoy de Souza e Lopes de Oliveira, 2012, p. 293); reinserção social.

A escola é um espaço privilegiado de promoção do desenvolvimento humano global pessoal e coletivo, assim como interpessoal e a subjetividade. Yokoy de Souza e Lopes de Oliveira (2012) fazem ainda importante crítica ao papel da escola que, segundo elas,

não se mostra preparada para abordar algumas das questões que são específicas do universo adolescente, tratando-as, por vezes, com grande inadequação. Temas como sexualidade, drogas, grupos e cultura juvenil, pouco se convertem em tópicos de cultura escolar, permanecendo como pauta exclusiva das trocas entre os próprios adolescentes, ocorridas nos corredores, banheiros e intervalos ( $p$. 295).

Há uma cultura negativa implantada pelas pessoas que convivem nas escolas, como estudantes, docentes, gestores e pais/mães de medo em relação ao adolescente em 
cumprimento de medida socioeducativa (Liberdade Assistida) que estão ali matriculados, por exigência do próprio ECA. Assim, o insucesso escolar é uma realidade e a dimensão pedagógica da medida socioeducativa deixa de ter primazia e mais, deixa de ser "efetiva, contínua e significativa" (Yokoy de Souza \& Lopes de Oliveira, apud Roman, 2012, p. 300). Deixa de ser um espaço de trocas interativas entre alunos-professores.

O episódio frequente de violência é sentido por todos os envolvidos. Por esse motivo, em 2009 a então Secretaria de Estado de Educação do Distrito Federal - SEEDF, realizou uma pesquisa diagnóstica sobre a realidade das escolas públicas em todo o Estado, com a finalidade de, após os resultados, usar como fundamento para ações e políticas, especialmente no que diz respeito à violência na escola.

A pesquisa, que foi uma iniciativa da Política de Promoção da Cidadania e Cultura de Paz da SEEDF, ouviu cerca de 9.937 estudantes da 5ª série do Ensino Fundamental ao $3^{\circ}$ ano do Ensino Médio e 1.110 professores/as, espalhados pelas 14 Regionais de Ensino, num total de 84 escolas. O Batalhão Escolar também esteve envolvido no processo, assim como Equipes Diretivas das escolas.

Entre outras coisas, a pesquisa mostrou atos considerados violentos manifestados de diversas formas: "incivilidades, agressões verbais, humilhações e violência simbólica, dessa forma, entram para o rol de atitudes que podem ser consideradas violentas. Assim, a violência é entendida como aquela que aniquila os corpos e arruína as mentes dos indivíduos" (Abramovay, 2009, p. 21, apud Zaluar E. Leal, 2001).

Nesse caso, a comunicação é o principal recurso a ser utilizado na redução de atos de violência, contudo, a ausência de argumentação e a instauração de poder de um indivíduo sob outro dificultam a comunicação pelo simples fato de emudecer, em muitos casos, as pessoas.

Os tipos mais comuns de violência encontradas na escola são: violência dura aqueles que podem resultar em danos irreparáveis aos indivíduos envolvidos e exigem intervenção do estado. Microviolências e incivilidades - passam despercebidas por muitos, inclusive o Estado e se compõe de desordens, pequenas ameaças, ofensas, algazarras e tipos diversos de barulhos. Violência simbólica - como forma de dominação, ou seja, "se baseia na fabricação de crenças no processo de socialização que fazem com que as pessoas se enxerguem e se avaliem de acordo com os critérios definidos por alguém com mais poder" (p.25). Outras situações também acontecem no cotidiano escolar, tais como: roubos e furtos, gestos e atos físicos, olhares, zombarias, isolamento, racismo, desigualdade social, de gênero, religiosa, econômica, conflitos, tensões, drogas, vandalismo, comportamento de oposição (Oliveira, 2012). 
Quando a questão envolve estudantes em cumprimento de Liberdade Assistida, a pesquisa mostrou que entre seus pares, $40,04 \%$ dos entrevistados não gostariam de ter convivência com esses adolescentes. Para os docentes, 16,8\% não gostariam de tê-los como alunos. Essa pergunta foi feita aos entrevistados com o objetivo justamente de saber como são recebidos os alunos em LA e quais imagens são feitas a respeito deles, assim como que tipo de acompanhamento recebem e quais são suas principais demandas.

Embora a finalidade pedagógica e educativa seja um dos princípios norteadores das medidas socioeducativas, não se pode esquecer seu caráter jurídico e impositivo. 0 adolescente deve ser acompanhado nas atividades escolares - frequência e rendimento, convivência familiar e de trabalho. Tudo isso a fim de promover a reinserção social tanto com a família quanto com a comunidade. A realidade mostra, porém, que a sensação de insegurança perpassa todos os envolvidos nas Unidades Escolares. A não aceitação das medidas socioeducativas seja por parte de professores, diretores e demais agentes que atuam nas unidades socioeducativas, como é o caso da escola regular acaba por enviesar o caráter pedagógico-educativo. O clamor pela diminuição da idade penal já era, em 2008/2009, amplamente defendido pelos profissionais de educação nas escolas públicas.

Rebeldes, marginais, desocupados, são alguns dos adjetivos dados aos estudantes adolescentes autores de ato infracional no ambiente escolar. São estereótipos, discriminações, fadados a um desenvolvimento humano negativamente comprometido ou que vá atrapalhar a dinâmica "institucional e social" (Yokoy de Souza \& Lopes de Oliveira, 2012, p. 182). São assim, "coisificados" no ambiente escolar. Todavia, à escola caberia a função de "envolver o adolescente que cumpre medida socioeducativa, aguçar sua curiosidade, articular-se com sua visão de mundo e colaborar na reorganização da sua vida" (p. 304).

\section{A Socioeducação e a História da Educação no Brasil}

Começamos a fundamentação teórica desse trabalho abordando, em linhas gerais, como se deu o processo de implantação da educação formal no Brasil. Percebemos então que a educação preconizada para os filhos da elite sempre foi excludente, mas causa-nos estranheza ao perceber que ainda hoje, a mesma escola que apregoa a inclusão dos diferentes, ou uma escola para todos, se constitui um lugar de exclusão socioeconômica e educacional de crianças e adolescentes.

O Relatório Educação Para Todos no Brasil 2000-2015 elaborado pelo Ministério da Educação em colocado e consulta pública em 2014, mostra um balanço dos avanços 
brasileiro em relação às seis metas de Educação para Todos, compromisso assumido pelos 164 países que participaram, em Dakar, no ano de 2000. Esses compromissos são: cuidado e educação na primeira infância; educação primária e universal; habilidades de jovens e adultos; alfabetização de adultos; paridade e igualdade de gênero; e qualidade da educação.

Sabemos que a legislação brasileira é bem completa ao amparar o direito à educação dos cidadãos desde a infância (vide Constituição Federal artigos 205, 208, 209, 211), assim como a Lei de Diretrizes e Bases da Educação e o Estatuto da Criança e do Adolescente, que acompanha as determinações da Constituição Federal. Entretanto, mesmo com a ampliação da oferta de ensino básico ocorrida entre os anos de 2000 até 2015, em todos os níveis de ensino, de acordo com Ferreira (2010) os adolescentes autores de ato infracional ainda são o público alvo da educação considerados excluídos desse processo de Educação para Todos, não apenas pela falta de acesso, mas também de permanência na escola.

Em que pese a escolarização dos adolescentes autores de ato infracional, a Equipe de Auditoria do Tribunal de Contas da União em pesquisa com adolescentes em conflito com a lei, mostrou que $23,46 \%$ dos entrevistados com média de idade de 12 anos, estava cursando até a 4⿳a série do ensino fundamental. $55,72 \%$ cursavam do $6^{\circ}$ ao $9^{\circ}$ ano; $14,66 \%$ o ensino médio e $6,16 \%$ não informaram o grau de escolaridade. Nesse sentido, Ferreira (2010, p. 311), observa:

Os dados preocupam, mas não se pode esquecer do contexto nos quais esses números estão inseridos, ou seja, no Brasil a escolaridade média de população, entre 15 e 24 anos, é inferior a oito anos de estudo, mas atinge 11 anos entre os jovens da elite na região Sul do Brasil e no Chile, que supera 10 anos.

A Socioeducação, por sua vez, nos mostra um quadro semelhante de precariedade da educação de adolescentes e jovens ao que se acrescenta um crescimento cada vez maior dos atos de violência cometidas contra esses cidadãos. O professor Júlio Jacobo Waiselfisz é o responsável, desde 1998 pelo estudo e divulgação do mapa da violência no Brasil. A publicação feita em 2016, mostra que ainda hoje os jovens negros na faixa etária de 15 a 29 anos de idade são as maiores vítimas da violência no país. Dessa forma, entre 1980 e 2014 há um aumento em torno de 699\% nos casos de mortes de adolescentes e jovens por armas de fogo. Conforme o Mapa da Violência 2014 as maiores vítimas dessa 
violência são jovens negros, "A vitimização negra no país que, em 2003 , era de $71,7 \%$ (morrem, proporcionalmente, $71,7 \%$ mais negros que brancos), pula para $158 \%$, em 2014" (Waiselfisz, 2016, p. 61).

Pinto e Silva (2014) ao discorrerem sobre a escolarização do adolescente em conflito com a lei e que esteja em cumprimento de medida socioeducativa, salientam que os centros socioeducativos devem buscar o estreitamento das relações com a escola, inclusive no sentido de afinar as propostas pedagógicas de ambos os setores visando à complementação e integração das ações, sem sobreposição uma à outra. Entretanto, a prática dessa perspectiva é um desejo que as escolas têm, ou seja, a aproximação das ações do sistema judiciário, que aplica a legislação vigente ao autor de ato infracional. Fato que está longe de se concretizar. Isso porque há uma grande barreira entre a escola e o sistema socioeducativo no sentido de parceria efetiva para além da obrigatoriedade de matricular o estudante na escola, mas não de manter diálogo com os profissionais que, no ambiente educativo, tem de estar preparado para lidar com toda e qualquer situação envolvendo o universo estudantil infantil, adolescente e adultos. O que se percebe é que o ambiente escolar acaba por ser sufocado por uma série de burocracias e entraves que dificultam a concretização do seu papel de (re) socialização do adolescente em cumprimento de medida socioeducativa. 


\section{IV- OBJETIVOS}

Essa pesquisa trata da atuação do Pedagogo-Orientador Educacional na rede pública de ensino do Distrito Federal. Nesse sentido, teve como Objetivo Geral:

- Analisar a atuação do Pedagogo-Orientador Educacional junto aos estudantes em cumprimento de medida socioeducativa.

\section{Objetivos Específicos}

- Identificar e analisar o acolhimento e acompanhamento aos estudantes em cumprimento de medida de Liberdade Assistida em escolas da Rede Pública de Ensino do Distrito Federal;

- Conhecer a participação do Pedagogo-Orientador Educacional em relação ao processo de acolhimento e acompanhamento aos estudantes em cumprimento de medida socioeducativa na escola. 


\section{V - METODOLOGIA}

O presente capítulo apresenta e metodologia utilizada na pesquisa, de natureza qualitativa, que teve como inspiração os pressupostos da Epistemologia Qualitativa desenvolvida por González Rey (2005, 2010).

\section{A Epistemologia da Pesquisa Qualitativa em González Rey}

Os princípios epistemológicos aplicados à metodologia qualitativa são considerados por González Rey (2005) como sendo o fundamento da produção científica, os quais possuem o caráter histórico-cultural tanto do seu objeto de pesquisa, quanto da consideração do conhecimento como construção predominantemente humana, sem excluir, entretanto, os processos subjetivos que perpassam o desenvolvimento humano em todas as suas etapas. Nesse sentido, "A epistemologia qualitativa é um esforço na busca de formas diferentes de produção de conhecimento em psicologia que permitam a criação teórica acerca da realidade plurideterminada, diferenciada, irregular, interativa e histórica, que representa a subjetividade humana" (González Rey, 2005, p. 29).

A epistemologia qualitativa é orientada por três princípios base necessários para o seu entendimento e aplicabilidade na pesquisa qualitativa em psicologia (González Rey, 2005). Em primeiro lugar, O conhecimento como uma produção construtiva-interpretativa: o conhecimento não consiste no acúmulo de informações dadas no momento empírico da pesquisa, pelo contrário, são as expressões dos sujeitos pesquisados que dão sentido interpretativo nos processos de construção de conhecimento, ainda que esses sentidos não estejam explícitos. Esse entendimento do caráter construtivo-interpretativo envolve um processo complexo contínuo no qual pesquisador e pesquisado são sujeitos ativos na produção de pensamentos e sentidos. Representa o diálogo constante entre a informação produzida e a interpretação do pesquisador e a construção de conhecimento. Esse é o processo dialógico, que envolve pesquisador, pesquisado e a base teórica assumida.

Em segundo lugar, reconhece o caráter interativo do processo de produção do conhecimento - nesse princípio, González Rey (2005) enfatiza que as interações ocorridas durante todo o processo de produção de conhecimento advindo da pesquisa envolvem, em grande medida, a interação (formal e informal) entre pesquisador e pesquisado. Esse processo é considerado como sendo essencial à produção construída tendo como cenário e contexto, os sujeitos nela envolvidos. Sob esse aspecto, o autor observa: "Toda pesquisa 
qualitativa deve implicar o desenvolvimento de um diálogo progressivo e organicamente constituído, como uma das fontes principais de produção de informação" (p. 56).

O terceiro princípio diz respeito à consideração da Singularidade como nível legítimo da produção do conhecimento - esse processo reconhece a importância da singularidade vista como individualidade do sujeito na constituição e reconstituição de sua subjetividade constituída pela cultura do sujeito e seu meio, suas expressões individuais e sentidos que dá às experiências vivenciadas enquanto pessoa. É justamente a singularidade do sujeito pesquisado que dará vasão à produção de conhecimento por parte do pesquisador no curso da pesquisa.

De uma maneira geral, González Rey mostra que a epistemologia qualitativa deve observar os princípios da construção interativa da constrição de conhecimento, assim como a dialogicidade entre pesquisador e sujeito pesquisado e a singularidade do sujeito, presente no curso da pesquisa. Dessa forma, esses diferentes princípios apontados levam à diferentes formas de se produzir conhecimento, cujo desenho metodológico traz grandes desafios ao pesquisador.

\section{A Ética na Pesquisa Qualitativa}

A ética na pesquisa qualitativa, não pressupõe apenas a apresentação e submissão ao Conselho de Ética em Pesquisa Humana do projeto da proposta de trabalho que se pretende desenvolver, mas também o respeito à fala do sujeito participante, assim como a fidelidade e fidedignidade das informações recolhidas.

O tratamento ético garante também o devido retorno, aos sujeitos participantes, sobre as considerações ou conclusões finais da pesquisa desenvolvida. Flick (2006) considera a ciência social e livre e cita, inicialmente, os códigos de ética das associações profissionais e acadêmicas, que regem os princípios morais de cada segmento e aponta quatro diretrizes básicas, estabelecidas a partir de 1980, para a condução de ciência indutiva quais sejam (p.146-147):

1. Consentimento informado - compromisso relativo à autonomia individual do participante em prestar informações e desligar-se da pesquisa a qualquer momento, assim como o direito de ser informado sobre a natureza da pesquisa e seus experimentos, que é o que hoje conhecemos como Termo de Consentimento Livre e Esclarecido (TCLE); 
2. Não Fraude - postura de ética da ciência social com uniforme contrária à fraude dos dados recolhidos e o uso fraudulento, seja por omissão ou falsificação de dados;

3. Privacidade e confidencialidade - diz respeito à proteção dos dados dos sujeitos participantes da pesquisa, quanto dos locais em que foram recolhidos os dados;

4. Precisão - assegurar a precisão dos dados, evitando-se a falsidade das informações, omissão, manipulação, uso de materiais escusos, maquinações.

O não cumprimento desses e de outros critérios na recolha de informações da pesquisa qualitativa, são considerados antiéticos e antiestéticos por parte do cientistapesquisador. Valores, crenças, subjetividade, entre outros devem fazer parte da sua visão de mundo, já que não há possibilidade de ser um sujeito neutro na realização da pesquisa.

Ademais, a ética social ou dialógica, consiste no entendimento da ética filosófica da pesquisa. Sobre isso, Flick ainda pondera:

Em vez de buscar princípios neutros aos quais todos os grupos possam recorrer, a ética social depende de uma visão complexa dos julgamentos morais como se esses integrassem um conjunto orgânico, uma experiência cotidiana, crenças a respeito do bem e sentimentos de aprovação e de vergonha, em termos de relações humanas e de estruturas sociais (p. 150).

Trata-se de integrar a vida humana, a partir da ética moral aos processos de construção de conhecimento através da pesquisa qualitativa das ciências sociais.

\section{Procedimentos Metodológicos}

Os procedimentos metodológicos adotados na consecução da pesquisa qualitativa possibilitam a geração de "diálogos formais e informais entre o pesquisador e os próprios participantes, os quais adquirem grande importância, pois são parte de informação sobre o problema pesquisado", afirma González Rey (2005, p. 85).

A dialogicidade do processo de construção da pesquisa, sustenta Gonzalez Rey (2005) é preponderante na constituição do conhecimento construído pelo pesquisador. Assim, acaba por levantar informações, para além do que foi previamente preconizado ou estabelecido, e que são relevantes para os processos que compõem o fazer ciência ou 
construção de conhecimento (p. 87). A seguir, são explicitados os procedimentos utilizados na pesquisa em destaque.

O encontro com os adolescentes estudantes que participaram da pesquisa representou um momento de construção das informações sobre a percepção deles sobre assuntos de seu universo, foi também, um momento de aprendizado mútuo, da pesquisadora e dos adolescentes presentes.

Solicitamos um número de 15 adolescentes, de ambos os sexos e diferentes idades, dentro do público alvo da instituição de ensino, que tivessem ou não passado pelo sistema socioeducativo na sua trajetória de vida. Porém, foram encaminhados para o local previamente preparado, todos os estudantes considerados relapsos por algum motivo, os chegaram atrasados na escola, os que 'dão trabalho', estão fora da faixa, apesar de estarem na EJA, e, entre esses, alguns que já haviam cumprido algum tipo de medida socioeducativa. Esse fato dificultou a construção das informações que se pretendia para aquele momento, visto que os estudantes encaminhados para a oficina não sabiam porque estavam sendo levados para o local e perdeu-se um tempo precioso na tentativa de convencê-los a participar. Felizmente, tudo se resolveu, mas a situação poderia ter sido evitada se tivesse havido mais colaboração por parte da escola.

À medida em que chegavam à sala, e tinham que estar ali, pois foram enviados para lá compulsoriamente, mostravam-se surpresos e logo perguntavam se estavam ali para serem chamados à atenção por algo de errado que tinham feito, ou assinar ocorrência, coisas assim. A pesquisadora tratou de dizer que não: estavam ali porque foram convidados para participar de uma pesquisa sobre as percepções adolescentes na escola. E assim foi dito a cada um que chegou. Por fim, foram se acalmando.

Inicialmente, após a apresentação pessoal da pesquisadora e da pessoa de apoio para registro das informações, falamos sobre o tema da pesquisa e quem fora convidado a participar. Foi-lhes dito também sobre o caráter voluntário da participação deles e que, se em algum momento, algum deles quisesse sair, podia ficar à vontade. Ficamos com o total de 14 adolescentes do sexo masculino, com idades entre 14 e 18 anos de idade, alunos do 5o ao $8^{\circ}$ ano do ensino fundamental.

Para explicar a forma como seria a oficina de jogos teatrais desenhamos na lousa uma árvore, simbolizando a Árvore do Oprimido, idealizada por Boal, mostrando as formas de expressão humana através do teatro, com foco central na imagem, na palavra e no som. Anteriormente, nosso desejo era solicitar que o grupo dissesse 3 palavras sobre o universo adolescente e, se entre elas não aparecesse a palavra socioeducação, a mesma seria escrita pelo pesquisador. 
Entretanto, devido às alterações na forma como o processo foi realizado, com os adolescentes já cientes do que aconteceria durante a oficina e a inquietude deles por estarem ali, quase que de forma impositiva, escrevemos na lousa, ao lado da árvore desenhada, 4 palavras, a saber: escola, cultura, perigos e socioeducação. Os estudantes foram divididos em 3 grupos e poderiam, utilizando imagens, palavras ou sons, colocar as suas percepções sobre as palavras apontadas. Antecipadamente a pesquisadora agradeceu a colaboração de todos e deixou e-mail de contato para todos que quisessem tirar dúvida ou conversar posteriormente.

De início houve dificuldade por parte deles em começar a atividade e sobre de que forma se expressar. Mas, com a mediação da pesquisadora aos grupos, a pedido deles próprios, todos decidiram se expressar em forma de hip hop, estilo musical preferido por eles. Cada grupo teve 15 minutos para fazer a atividade e 5 minutos para se apresentar. Nesse sentido, tudo fluiu melhor e cada grupo apresentou seu 'produto final' aos outros de maneira ritmada e bem peculiar, com gestual e entonação próprios.

\section{Contexto de Pesquisa}

O Distrito Federal possui hoje, cerca de 800 Pedagogos-Orientadores Educacionais espalhados por quase 700 escolas públicas em todas as cidades satélites. Esse número de profissionais está distribuído nos três turnos de trabalho, mas ainda assim, ainda há unidades de ensino sem pessoal atuando no Serviço de Orientação Educacional (SOE).

O Pedagogo-OE está lotado desde escolas de Educação Infantil, Ensino Fundamental, Médio, Ensino Especial, Educação de Jovens e Adultos, Escolas Parque e Centro de Línguas. Interessante notar, que embora haja um clamor por um limite de estudantes por profissional nas escolas, a realidade mostra até 2.000 alunos por PedagogoOE.

Da mesma forma, não há um limite de matrícula de estudantes em cumprimento de medida socioeducativa por escola. Geralmente apenas o adolescente autor de ato infracional com regime em meio aberto - Liberdade Assistida ou semiliberdade, ou mesmo que necessite fazer a reparação do dano, pode ser matriculado em escolas regulares. Aos que estão em regime de privação de liberdade, a própria unidade de internação deve ter escola em funcionamento na própria instituição. Os professores lotados nessas unidades são da rede pública de ensino.

É nesse cenário que atua o Pedagogo-Orientador Educacional alvo da pesquisa, com suas atividades, limitações e perspectivas. 


\section{Questões de Pesquisa}

Resgatando o objetivo: Analisar a atuação do Pedagogo-Orientador Educacional junto aos estudantes em cumprimento de medida socioeducativa, a presente pesquisa lança o olhar para as tramas que envolvem a escola na rede de atendimento socioeducativo, suas possibilidades e desafios. Nesse sentido, as questões de pesquisa foram:

1. Como o Pedagogo-OE e a respectiva instituição de ensino pesquisada compreendem o papel da escola na rede socioeducativa?

2. De que maneira é feito o acolhimento e acompanhamento do estudante adolescente que esteja em cumprimento de medida de LA?

3. Como a instituição de ensino trabalha no sentido da inclusão de estudantes em cumprimento de medida socioeducativa?

4. Qual a sua percepção da compreensão que a escola onde atua tem da Socioeducação? Como o Pedagogo-OE e a respectiva instituição pesquisada compreendem o papel da escola na rede socioeducativa?

5. De que maneira é feito o acolhimento e acompanhamento do estudante adolescente que esteja em cumprimento de Liberdade Assistida?

6. Quais as contribuições da instituição de ensino na inclusão de estudantes adolescentes em cumprimento de medida de LA?

\section{Participantes}

Os participantes adultos da pesquisa foram 04 Pedagogos-Orientadores Educacionais (de ambos os sexos) advindos de 03 escolas públicas diferentes, com tempos distintos de atuação profissional na SEEDF, na modalidade de Ensino Médio e na Educação de Jovens e Adultos, no período diurno.

\section{Quadro 01- Caracterização dos Pedagogos-Orientadores Educacionais}

\begin{tabular}{|c|l|l|l|}
\hline Participante & \multicolumn{1}{|c|}{ Formação } & $\begin{array}{c}\text { Modalidade de } \\
\text { atuação }\end{array}$ & $\begin{array}{c}\text { Tempo de } \\
\text { atuação }\end{array}$ \\
\hline A & $\begin{array}{l}\text { Pedagoga com pós-graduação em } \\
\text { Psicopedagogia; Gestão educacional e }\end{array}$ & $\begin{array}{l}\text { Educação de } \\
\text { Jovens e Adultos. }\end{array}$ & 8 anos \\
\hline
\end{tabular}




\begin{tabular}{|c|l|l|l|}
\hline & Orientação Educacional & Ensino Médio. \\
\hline B & $\begin{array}{l}\text { Pedagoga, com Pós-graduação em } \\
\text { Gestão Escolar e temas } \\
\text { contemporâneos da Educação }\end{array}$ & 18 anos \\
\hline C & $\begin{array}{l}\text { Pedagoga com Pós-graduação em } \\
\text { Psicomotricidade. }\end{array}$ & Ensino Médio. & 07 anos \\
\hline D & $\begin{array}{l}\text { Pedagogo com Pós-graduação em } \\
\text { Orientação Educacional Gestão } \\
\text { Educacional. }\end{array}$ & $\begin{array}{l}\text { Educação de } \\
\text { Jovens e Adultos. }\end{array}$ & 07 anos \\
\hline
\end{tabular}

O ambiente escolhido pelo grupo de participantes adultos foi a sala do Serviço de Orientação Educacional (SOE), local, segundo eles propício para conversarmos com tranquilidade, embora houvesse expediente normal na escola, com estudantes por toda parte, aulas, atividades diversas. Houve a menção de que anteriormente, nem sempre o espaço físico reservado ao trabalho da Orientação Educacional foi respeitado nas escolas públicas do Distrito Federal, o que nos dá oportunidade de iniciarmos o debate proposto item a item.

Os participantes adolescentes foram 14 estudantes de diferentes turmas de apenas uma das escolas, do sexo masculino, na faixa etária de (14 a 17 anos e 9 meses de idade). Esse grupo mesclou alunos que tinham cumprido ou estavam cumprindo medida socioeducativa e outros que não estavam nessa condição. Considerou-se que como os estudantes pertencentes e os não pertencentes à Rede Socioeducativa conviviam no cotidiano nos mesmos espaços escolares, o grupo de participantes deveria ter a mesma configuração.

\section{Etapas}

A construção de informações envolveu inicialmente, visita à Regional de Ensino e instituições de ensino escolhidas, cuja identificação não será exposta na pesquisa. A visita a ambas as instituições serviu como uma aproximação ao fenômeno e contexto investigados para levantar o interesse das mesmas e de seus respectivos Pedagogos-OE em participar da pesquisa. Por ocasião dessas visitas, foram obtidos os Projetos Político Pedagógicos das escolas dos participantes. 
Posteriormente, estivemos nas unidades de ensino escolhidas para participar da construção das informações conversando com os Pedagogos-OE sobre a pesquisa, e ao mesmo tempo, sondar sobre o melhor dia, hora e local para o encontro com os demais colaboradores. Decidimos também, marcar a recolha de informações com os estudantes adolescentes oriundos de apenas uma das escolas, facilitando assim o encontro, sem a necessidade de os mesmos se ausentarem da escola de origem sob a responsabilidade da pesquisadora.

Após a construção das informações, procedeu-se à degravação das mesmas e ao início da Análise e posterior Discussão à luz da fundamentação teórica assumida e utilizando-se de indicadores na perspectiva de González Rey $(2005,2010)$.

\section{Instrumentos}

Os instrumentos utilizados para a construção das informações dos Pedagogos-OE consistiram de: a) Formulário de caracterização pessoal, contendo: nome completo, data de preenchimento, idade, gênero, tempo de formação, formação complementar, tempo de atuação na SEEDF; b) Fórum de discussão no qual foram colocados, um a um, seis tópicos os quais definem as questões de pesquisa:

1. O que é ser Pedagogo-Orientador Educacional na Rede Pública de Ensino do Distrito Federal?

2. Qual a sua compreensão sobre a Socioeducação?

3. Que tipo de conhecimento teórico/prático você julga importante para contribuir com seu trabalho junto aos jovens do contexto da Socioeducação?

4. Qual a sua percepção da compreensão que a escola onde atua tem da Socioeducação? Como você, Pedagogo-OE e a sua instituição de ensino compreendem o papel da escola na rede socioeducativa?

5. De que maneira é feito o acolhimento e acompanhamento do estudante adolescente que esteja em cumprimento de medida de LA?

6. Quais as contribuições da instituição de ensino na inclusão de estudantes adolescentes em medida de L.A.?

$\mathrm{Na}$ construção das informações com os estudantes adolescentes participantes da pesquisa, foi realizada uma oficina de Jogos Teatrais, na perspectiva do Teatro do Oprimido 
(TO), idealizado por Augusto Boal (2013). O TO foi preconizado a partir do projeto A Estética do Oprimido, que:

busca envolver, aos que o praticam a sua capacidade de perceber o mundo através de todas as artes e não apenas o teatro, centralizado esse processo na palavra (todos devem escrever poemas e narrativas); no som (invenção de novos instrumentos e de novos sons); na imagem pintura, escultura e fotografia). Cada folha dessa árvore faz parte indissolúvel dela até alcançar as raízes da terra ( $p$. 15).

Todo esse processo é denominado de A árvore do Oprimido. Simbolicamente falando, e conforme mostra a figura abaixo, os frutos, ao caírem no solo, permitem a possibilidade tanto de reprodução quanto de multiplicação - transformação. A solidariedade entre semelhantes é considerada, como parte medular, na perspectiva do TO.

O tronco representa a vida em sociedade: com suas regras, leis, liberdade criativa, no jogo ou na vida. Boal reforça que não é uma atitude de "servil obediência, mas de regras", ou seja, "Sem regras não há jogo, sem liberdade não há vida" (p. 16).

Os jogos permitem também a dinamicidade do corpo e da mente, o que os diferencia das tarefas que exigem repetição no cotidiano da vida. Estimula o diálogo, em cuja criatividade consiste a sua essência, assim como a palavra, que possibilita a produção de sentidos.

Assim, o TO utiliza-se dos seguintes jogos ou atividades, ou ainda concepções :na sua metodologia de trabalho: Teatro Imagem (dispensa o uso da palavra); Teatro Jornal (transformação de textos jornalísticos em teatrais); Teatro Fórum (os expectadores, são sua característica central, os quais são convidados a entrar em cena e modificá-la); Espetáculo Invisível (na rua, na praça, ônibus, cinema feiras - protestos, marchas, desfiles, concentrações, entre outros, organizadamente); Teatro Legislativo (mistura vários dos jogos acima citados para formulação em conjunto com outros grupos e pessoas, para proposição de projetos de leis).

As figuras expostas a seguir fornecem ideias claras da organização e estrutura do TO representados de formas distintas. Uma delas é de criação livre, idealizada pelos estudiosos de Boal. Já a segunda consta de uma de suas obras. 
Figura 1 - A representação da árvore do Oprimido.

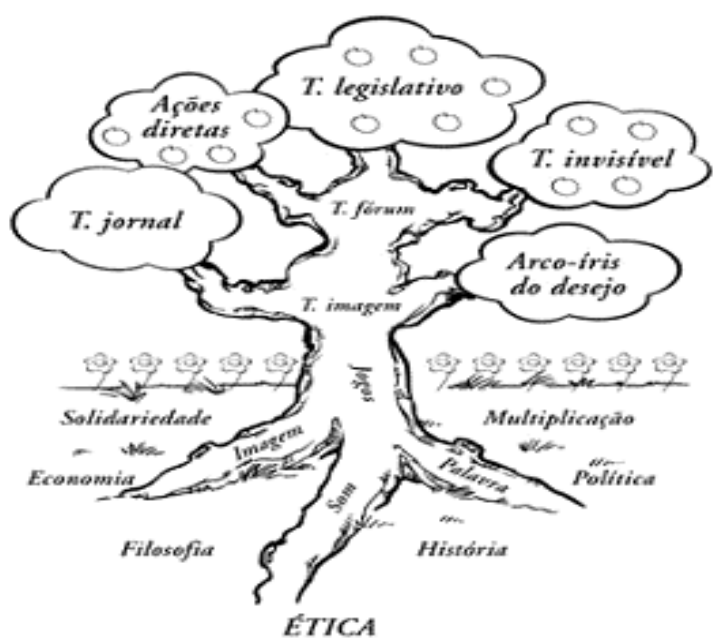

http://www.arte.seed.pr.gov.br/arquivos/Image/teatro/arvore_teat_oprimido_1.jpg

Figura 2 - A Operacionalização do Teatro do Oprimido.

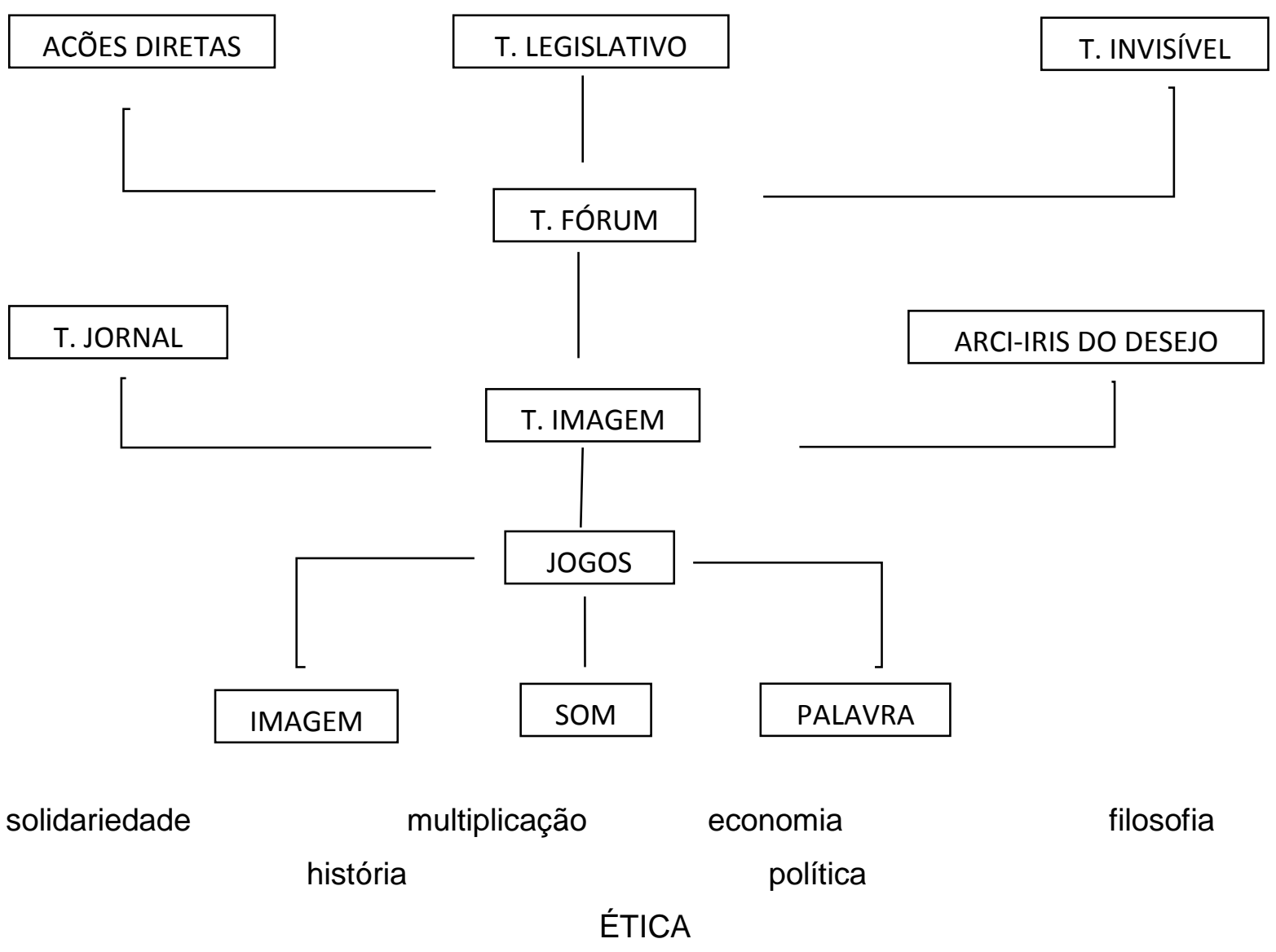

Boal, Augusto. (2013). Teatro do Oprimido e outras técnicas poéticas políticas: Augusto Boal. São Paulo: Cosac Naify. 
O principal objetivo da Árvore do Oprimido é a geração de frutos, flores e sementes, ou seja, conhecer a realidade e transformá-la. A oficina aconteceu da seguinte forma:

1. Os alunos escolhidos pela escola foram encaminhados à sala previamente preparada pela pesquisadora, na qual foram dispostos vários objetos que poderiam ou não ser utilizados na construção das informações, tais como: chapéus, lenços, fitas, folhas de papel pardo, canetas, pincéis atômicos, lápis de cor, entre outros.

2. À medida que os adolescentes chegavam foi-lhes dado boas-vindas e quando todos já estavam acomodados, a pesquisadora explicou-Ihes o motivo de estarem ali, ou seja, eles estavam sendo convidados a participar de uma pesquisa de mestrado, em que era importante a opinião deles, acerca de assuntos ligados ao dia a dia dos mesmos na escola em que estudavam.

3. A participação foi voluntária e qualquer um deles poderia se retirar quando achasse conveniente, sem prejuízo à pesquisa.

4. A pesquisadora explicou que as informações a serem recolhidas seriam através do método do Teatro do Oprimido, idealizado por Boal e que eles poderiam expressar sua opinião da maneira que desejassem, desde que utilizassem para isso qualquer uma das categorias: imagem, som ou palavra, juntas ou em separado.

5. Foram escritas na lousa 4 palavras-chave: escola, perigos, cultura e socioeducação.

6. Os estudantes foram divididos em 3 grupos e tiveram 15 minutos para criar a atividade proposta e 5 minutos para fazer a apresentação a todo grupo.

7. Durante o processo de construção da atividade, a pesquisadora foi solicitada pelos grupos para orientar e incentivar a criatividade dos estudantes, que foram informados que não se tratava de avaliação, não seria feito juízo de valor ou crítica sobre as opiniões.

8. Todos os grupos escolheram criar escrever hip hop para dar sua opinião e ao final apresentaram a todos.

9. Por fim, a pesquisadora fez as considerações finais e agradeceu a participação dos estudantes.

\section{O Diário de Campo}

O Diário de Campo foi um instrumento de elevada importância durante todo o decurso da pesquisa, utilizado de diversas formas e em diferentes momentos, por exemplo: 
no Laboratório Ágora de pesquisa na UnB, em encontros semanais entre todos os pesquisadores orientados por duas professoras da universidade. Nesses encontros procuramos discutir assuntos concernentes ao processo de pesquisa individual, assim como

discutir textos, livros, receber outros pesquisadores, entre outras atividades. É um momento riquíssimo de troca de experiência. Os registros das impressões pessoais e do grupo vão sendo feito no Diário de Campo e também foi utilizado em seminários, encontros e congressos ao longo da pesquisa.

As visitas às instituições envolvidas na pesquisa, como a Coordenação Regional de Ensino, a consulta às escolas e Pedagogos-Orientadores Educacionais e outros profissionais da escola, também foram alvo de registro no Diário de Campo, ou seja, as impressões, as entrelinhas das falas formais e informais, as dificuldades, as percepções para pesquisas futuras, os receios, entre outras percepções. Trata-se assim, de um instrumento imprescindível de auxílio no registro da trajetória do pesquisador.

\section{Tratamento e Análise das Informações}

A partir das informações construídas tanto da Pesquisa Documental quanto da Oficina de Jogos Teatrais na perspectiva de Augusto Boal (2013) e do Fórum de Discussão com Pedagogos-Orientadores Educacionais, procedeu-se à degravação de ambas as atividades para posterior análise.

Contudo, a análise representa um momento de grande inquietação para 0 pesquisador. O próprio formulário de levantamento de dados pessoais dos participantes é considerado um momento de fala dos participantes (Myers, 2010). O problema, a partir desse ponto é tentar reduzir ou padronizar "dados brutos a categorias e formas que o pesquisador possa usar em uma argumentação" (p. 271).

Nas análises da conversação procuramos averiguar tanto o conhecimento quanto as práticas na função desempenhada, as experiências vivenciadas, assim como as percepções em relação a cada item das questões propostas.

A análise das informações foi inspirada e construídas segundo a natureza teórica, epistemológica e metodológica construtivo-interpretativa, de González Rey (2005, 2010), que concebe, como principal característica da epistemologia da pesquisa qualitativa, a construção e interpretação do conhecimento em que pesquisador, contexto e pesquisado dialogam constantemente no transcurso dos processos de "construção teórica de sentidos subjetivos e de configurações subjetivas envolvidas nos diferentes comportamentos e produções simbólicas do homem" (González Rey, 2010, p. 116). Tais processos subjetivos 
são contínuos e estão presentes tanto nos comportamentos humanos quanto nas expressões advinda deles. González Rey (2010) reconhece também o caráter antropológico e sociológico da perspectiva sociocultural na Psicologia.

No processo de construção das informações de pesquisa, os sujeitos envolvidos se mostram mediante expressões faciais, falas, palavras, gestos, ou seja, nas mais diversificadas manifestações humanas em variados tipos de expressões. Confrontando-se momento empírico e marco referencial produz-se assim, o caráter construtivo-interpretativo da pesquisa científica, com a criação de indicadores permeados de inteligibilidade, permitindo criar uma representação da realidade que se propôs estudar.

Outro fator a ser observado é o papel ativo e de produção do pesquisador que se assume também como sujeito da pesquisa e não está no contexto da pesquisa apenas para realizar a recolha de dados. O caráter ativo do pesquisador pressupõe uma dinâmica em constante articulação com o momento empírico e a produção intelectual.

Com o propósito de realizar a análise e discussão das informações construídas e dar maior dinamicidade ao diálogo entre os processos de construção-interpretação, optamos por fazer a análise e discussão logo após cada pergunta de pesquisa. Dessa forma, criamos indicadores com bases nas expressões orais, entonações e percepções fundamentadas na subjetividade dos participantes. 


\section{VI - RESULTADOS E DISCUSSÃO}

Neste capítulo são apresentados os resultados da pesquisa, que teve, como objetivo geral, "Analisar a atuação do Pedagogo-Orientador Educacional junto aos estudantes em cumprimento de medida socioeducativa". Esses resultados foram organizados de acordo com os participantes da pesquisa trabalhando em três momentos.

No primeiro momento, reunimos todo o grupo de Pedagogos-OE's, em uma das escolas em que um deles ou mais atuam. Na ocasião realizamos um fórum de debate, no qual as questões de pesquisa foram, uma a uma, expostas aos participantes os quais puderam, assim, fazer a sua contribuição para as impressões e expressões sobre a temática em epígrafe. Todos os participantes, inclusive a pesquisadora, tiveram liberdade para fazer inserções, por meio de perguntas um ao outro ou mesmo complementação das informações uns dos outros sempre que julgou pertinente.

No segundo momento, e propositadamente após a realização do fórum de debate, foi feito a leitura e análise do Projeto Político Pedagógico das respectivas escolas a fim de analisarmos como as instituições escolares abordam a temática da Socioeducação em seus conteúdos ou projetos anuais, os quais são enviados à Coordenação Regional de Ensino correspondente ao local onde a escola está instalada. Verificamos que nenhuma das PPP faz menção ao acolhimento e acompanhamento de estudantes em LA ou mesmo relaciona atividades para lidar com os estudantes adolescentes nessa condição.

No terceiro e último momento, foi a vez dos estudantes participantes da pesquisa, que se reuniram com a pesquisadora para a realização de uma oficina, na qual foi utilizado a metodologia do Teatro de Oprimido, de Augusto Boal, para responderem às indagações sobre temas ligados ao seu universo adolescente no ambiente escolar.

As informações construídas com os Pedagogos-OE's serão doravante expostas na ordem em que foram feitas. Os mesmos foram identificados com letras do alfabeto de A-D. Seus nomes foram mantidos em sigilo, assim como não foram identificadas as características denominacionais das escolas colaboradoras, nem dos estudantes participantes da pesquisa.

As impressões e respostas dadas às questões levantadas nos levaram à construção de indicadores às questões de pesquisa que foram levadas ao campo, qual seja, o PedagogoOrientador Educacional e os estudantes em cumprimento de medida socioeducativa no contexto da escola. Esses indicadores não nos trouxeram respostas fechadas em respostas aos objetivos propostos, mas nos permitiram a busca por entender como se dá tanto o processo de acolhimento e acompanhamento ao estudante adolescente autor de ato infracional na escola, como nos permitiu ouvir também os estudantes e suas percepções 
sobre a escola à qual é encaminhado para matricular-se como atendimento ao direito universal à educação.

González Rey (2005, p. 112) introduz o conceito de indicador para "designar aqueles elementos que adquirem significado graças à interpretação do pesquisador, ou seja, sua significação não é acessível de forma direta à experiência, nem aparece em sistemas de correlação". Os indicadores são construídos com base nas informações que não estão claramente explícitas ou de forma direta, mas, pelo contrário, indicadores esses que aparecem na produção e construção de conhecimento e que estão para além do meramente dito ou expresso em palavras ou ações do pesquisado.

González Rey (2005) traz ainda outras considerações sobre a construção de indicador (es) no processo de pesquisa, quais sejam: é apontado como um caminho que possibilita tanto a alterações no problema de pesquisa, bem como mostra ou não a necessidade da adoção de novos instrumentos a serem utilizados na construção das informações; é também um "processo de construção teórica de complexidade constante" (p. 114); integra um procedimento contínuo de construção de conhecimento e facilita a viabilidade do mesmo; não tem valor se utilizado de forma isolada do contexto da pesquisa e; são produzidos com objetivo explicativo (dar sentido ao não-observável), e não descritivo do fenômeno estudado.

\section{Questão de pesquisa 01: O que é ser Pedagogo-OE na Rede Pública de Ensino do Distrito Federal?}

Quando nos reunimos com os Pedagogos-OE's, à princípio o momento conversacional foi bem informal. Falamos de diversos assuntos, rimos, nos abraçamos, observamos o espaço físico disposto ao atendimento no Serviço de Orientação Educacional. Mas percebemos que, na medida em que a questão inicial foi colocada, houve um misto de respiração longa, tensão, por parte de todos, inclusive da pesquisadora, talvez por não saberem de fato o que queríamos saber sobre o trabalho de cada um na sua escola de atuação.

Contudo, aos poucos, as expressões e impressões foram surgindo mais fluídas, assim como os relatos de reflexão e construção pessoal sobre a experiências vivenciadas no SOE e suas especificidades. Foi por esse motivo, ou seja, para dar um caráter de troca de informações e experiências a esse momento de construção de informações, que escolhemos usar um fórum de debate, onde cada participante pudesse trazer a sua contribuição à nossa pesquisa sem o constrangimento e a irritação que uma entrevista pode 
causar em algumas pessoas. Em resposta à essa primeira indagação tivemos as seguintes considerações:

Considero a pergunta difícil, embora entendo meu papel no ambiente escolar e a necessidade de se colocar no lugar do outro alteridade, ou seja, se colocar no lugar do outro para ver o que você pode fazer. E muitas pessoas não faz isso. O OE é um papel muito importante, é sim (Pedagogo-OE A).

...a $O E$ nada mais é do que uma facilitadora da aprendizagem... alguns colegas sem capacitação técnica, e isso é muito perigoso, enveredam por esse caminho da medicina, por esse caminho psicologizante da função de OE, sem capacitação técnica... psiquiatria, psicologia... isso se torna um problema. Assim não se consegue ajudar ninguém. E aí, em contrapartida vivemos uma frustação muito grande, porque além de não ter essa competência técnica de fato ou formação acadêmica, nós vivemos um papel de invisibilidade dentro da escola. Porque assim, a gente sabe que mudança de comportamento requer tempo. Se eu considerar que um menino de repente entra no $6^{\circ}$ ano numa escola $X$, eu só vou conseguir solidificar algumas coisas, só vou conseguir alguns resultados muito positivos no $1^{\circ}$ ano, se ele permanecer. Essa ação ... e é até por isso que eu discordo um pouco dessa história do Serviço, porque a literatura, além de não apontar, há a carência de literatura acadêmica, o meu entendimento de serviço é que tem um tempo pra se esgotar, e a ação não, ela é atemporal. A palavra é orientar. De que ponto de vista? Educacional. (Pedagogo-OE B).

À medida que eu atuo como Orientadora, são 8 anos apenas, à medida que a gente vai alcançando algum tempo, e alguma experiência de, sempre no sentido de querer ajudar, ali naquela escola como facilitadora da educação, eu acho que a fala que você coloca é muito pertinente, sabe, eu acho que a gente está aqui mesmo, a nossa função, eu acho que, o ponto de partida tem que ser esse, porque que eu estou na escola? Só que, eu me vejo, hoje, mais madura do que quando eu entrei. Eu já consigo me distanciar como Orientadora, dessa frustração. Quando você acredita só na 
rede de apoio público, não funciona. E aí gente, você vai e faz aquilo tudo" (Pedagogo-OE C).

Eu vejo que é o acolhimento. O grande desafio nosso hoje é o acolher e ter uma mentalidade, porque não é simples de falar o que é ser neutro... sem dogmas...numa forma de orientar... acolher... faz toda a diferença... ser profissional... ser ético... (Pedagogo-OE D).

\section{Análise e discussão da questão de pesquisa 01}

Nessa primeira questão, percebemos vários indicadores concernentes a indagação do que é ser Pedagogo-OE na rede pública de ensino e que nos levam a formular a seguinte hipótese: posição de reflexão e crítica ao trabalho do Pedagogo-OE no ambiente escolar aparecem inseparáveis. As falas, ao mesmo tempo trazem o registro do que é "ser", mas também, do que "não é ser" na sua área de atuação e o que pode acontecer quando se foge das especificidades da função no ambiente escolar. É o que Gonzáles Rey (2010, p. 130) afirma ser um: "relato em diferentes zonas de sua experiência pessoal, as quais são inseparáveis do sentido subjetivo".

Outro indicador percebido diz respeito à empatia e caráter de orientação estudantil e à família. Isso é demostrado da seguinte forma: "alteridade, ou seja, se colocar no lugar do outro para ver o que você pode fazer. Você tem que ser altero pra poder ajudar" (PedagogoOE A). E nesse momento o profissional procura enfatizar a necessidade de que, se você não se coloca no lugar do outro, fica mais difícil entender o que o outro sente e assim, poder ajudar, ou seja, se você estivesse no lugar daquele que procura sua ajuda, como você gostaria de ser orientado? Esse é o ponto principal no sentido da alteridade.

Ainda em reposta à primeira questão de pesquisa abordada, surge outro indicador 0 que cada um é e o que não é na sua função na escola, quando o Pedagogo-Orientador Educacional inclui ou exclui funções em seu papel na escola (o que é e o que não é função dele). Observamos essa identidade assumida na fala dos participantes:

Eu me coloco nesse papel de facilitadora da aprendizagem, porque o meu contexto é um contexto educacional. Eu não estou na escola pra tratar. Claro que essa questão da escuta, escutatória. Escutar é uma coisa, fazer os devidos encaminhamentos, fazer as interferências possíveis, porque nós temos um limite para a nossa 
atuação. A gente não consegue expandir muito além dos muros da escola. Nós até tentamos. Nós tentamos fazer essa interferência, eu reconheço" (Pedagogo-OE B).

Outro Pedagogo-OE diz:

Eu sou Orientadora Educacional. O que eu posso fazer por você nesse sentido? (Pedagogo-OE C).

Para outro:

Qual que é a minha função na escola? Facilitar. A partir do momento que eu penso nisso, facilitar, pra mim, esse, eu acho que é esse o verbo mesmo. Eu estou aqui pra facilitar? Então todas as minhas práticas vão ser inclinadas pra isso (Pedagogo-OE C).

Embora o enfoque principal da pesquisa seja na direção da abordagem da psicologia do desenvolvimento, é importante considerarmos que a educação está inserida nesse processo. Coll (2004) relaciona alguns espaços de atividade científica e profissional relacionados com a psicologia da educação, dentre os quais, os Serviços especializados de Orientação Educacional e psicopedagógica, assim como Serviços e programas de atenção educacional à infância, à adolescência e à juventude, seja em contextos escolares e não escolares (família, centros de acolhimento, centros de adoção, entre outros). O autor chama atenção também para um melhor entendimento do que sejam as relações entre psicologia e educação. Nesse ponto, a psicologia do desenvolvimento ajuda na compreensão da aprendizagem, tão necessária nas práticas educativas escolares.

Por outro lado, sabemos que o sujeito é constituído nas e pelas relações sociais, influenciado que é pelas condições históricas e materiais. É nesse sentido que Vigotski constrói a concepção histórico-cultural da psicologia do desenvolvimento. A partir das quais a pessoa é, ao mesmo tempo, sujeito e produto do meio (Alves \& Pedroza, 2016).

Relacionando a psicologia do desenvolvimento e a construção da identidade, entendemos a constante interação que permeia o trabalho do Pedagogo-OE, com a realidade social, cultural, política e econômica que o cerca. Por esse motivo, entender quem é como sujeito e qual seu papel no ambiente escolar é de grande importância para a consecução do seu trabalho no Serviço de Orientação Educacional. Alves e Pedroza (2016) observam também, que embora a obra de Vigotski não faça referência aos processos de 
construção da identidade sob o viés da subjetividade, em função do que ele propõe em sua obra, é possível inferir que estava se referindo a essa importante dimensão do humano na sociedade, que é objeto de estudo das Ciências Humanas.

No momento em que se colocam como facilitadores da aprendizagem no ambiente escolar em relação aos estudantes atendidos pelo Pedagogo-Orientador Educacional, Vigotski assinala, no entanto, o caráter da mediação da criança com o adulto no seu processo de desenvolvimento humano. É nesse processo que se dá a Zona de Desenvolvimento Proximal, que consiste naquilo que o sujeito consegue fazer sozinho e o que já é capaz de realizar sem a ajuda de um adulto. Na presente discussão, a mediação ocorre na tentativa de resolução de situações-problemas em regime de colaboração entre os envolvidos. Trata-se assim, "da mediação das ações humanas, como resultado da incorporação e do uso de múltiplas ferramentas e a de artefatos acumulados no contexto de determinada cultura" (Rivero \& Luna, 2012).

A construção da identidade como Pedagogo-OE envolve, segundo González Rey (2010), sistemas simbólicos, dimensões afetivas e sócio-históricas. Tal entendimento, de acordo com esse autor, permite ao profissional a delimitação do seu espaço e o reconhecimento pessoal dentro das diversas situações propostas. Indica assim, posicionamento. Cumpre dizer, não obstante, que a identidade não pressupõe um processo estático, imutável, ao contrário, passa por modificações à medida que a situação o exige, inserido que está no seu espaço histórico (Alves \& Pedroza, 2016). Sua identidade, por sua vez, se entrecruza, em categorias de indicador, com a dos demais sujeitos que atuam no ambiente escolar, quais sejam, professores, psicólogos, servidores, estudantes e pais, num compartilhamento de saberes historicamente constituídos e construídos. Nesse sentido, as dimensões social e pessoal na construção da identidade do sujeito convivem de forma dialética, modificando e sendo mutuamente modificadas.

A definição da identidade representa, segundo as autoras anteriormente citadas, um posicionamento subjetivo. Em suma: “... há, necessariamente, uma postura ativa do sujeito (...) se trata de uma configuração dinâmica e nunca rígida, pois depende de fatores históricos, sociais e situacionais para emergir como identidade" (p. 46).

Ao apontar para o perigo de o Pedagogo-OE agir de forma contrária à sua função no ambiente escolar, o participante B está chamando a atenção para a vinculação simbólica e afetiva que pressupõe o assumir-se enquanto tal, identificando-se com um grupo de profissionais que atuam no ambiente escolar em uma função por vezes de invisibilidade perante aos demais profissionais ali envolvidos, o que exige um posicionamento forte e assumido. 
Para finalizar a análise da primeira questão de pesquisa, ou seja, O que é ser Pedagogo-OE na SEEDF, temos como indicador a posição pessoal frente aos desafios no ambiente escolar, encontrada na afirmação: "Sobre a questão da OE, eu penso que é uma profissão muito dinâmica... não tem como não ser" (Pedagogo-OE C). A conotação identitária da Orientação Educacional denota posição ao mesmo tempo crítica e vigilante quanto aos fatores envolvidos no dia a dia do trabalho do SOE.

\section{Questão de pesquisa 02: Qual a sua compreensão sobre a Socioeducação?}

Em outras palavras, queremos saber na verdade o que o profissional sabe sobre Socioeducação, até porque essa indagação foi feita a mim mesma como pesquisadora antes de iniciar as atividades no Mestrado.

A primeira coisa que vem na minha cabeça quando você fez a pergunta, é a questão da discriminação... eu não vou dizer que é por parte dos colegas não, por minha parte mesmo...eu não conheço, eu não busco, eu não tenho a experiência de ter ido nunca a um lugar desses... O meu trabalho com esses alunos foi muito pontual, individual. Nós temos a intenção que esses meninos possam se ajustar (Pedagogo-OE C).

Era uma coisa que tinha que ser uma parceria, a escola parece que tá sendo o depósito... eles tem que vim pra escola porque eles são obrigados por lei a estarem na escola... e a gente é obrigado a receber... é uma, não há parceria... é uma coisa muito solta. Se tivesse uma parceria, a gente iria bem. Faríamos o nosso papel de orientar e não apenas de acolher. (Pedagogo-OE A).

O aluno chega na escola empoderado e aqui descobre que tem que passar nas disciplinas e não tem o apoio de ninguém... então, eu chamo o aluno e tenho com ele uma conversa de homem pra homem, e falo, eu conheço esse sistema, já fui conhecer a Papuda, o Caje... então aqui, qual o acompanhamento que ele vai receber? (Pedagogo-OE D). 
Eu acho que esse assunto é uma pauta que nós tínhamos que estudar juntos, sabe, pra gente saber como acolher. A escola tem que manter o sigilo sobre a situação do aluno, mas e quando eles mesmos espalham isso. Os professores ficam armados. Às vezes o acolhimento é muito vago. (Pedagogo-OE C).

A gente tem uma rede de proteção falha... a escola precisa trabalhar com a prevenção... se as outras redes falham, ora nós temos que trabalhar com a repressão...não há locais para onde encaminhar os alunos, se eu tivesse uma rede que me possibilitasse que ele não chegasse a uma situação de LA.... a rede de saúde, polícia militar, a assistência social dos próprios Conselhos Tutelares...o contato precisa ser maior e melhor" (Pedagogo-OE B).

Você encaminha, mas não sabe o que vai acontecer... e a demora no atendimento? É todo um processo. (Momento de várias falas ao mesmo tempo).

\section{Análise e discussão da questão 02}

Nesse ponto, o indicador que depreendemos, diz respeito ao reconhecimento da incompletude das políticas públicas na rede socioeducativa. A Socioeducação faz parte da política de proteção à infância e adolescência no Brasil. Fundado nessa perspectiva, esse público alvo tem, garantido por lei, o entendimento de pessoa como sujeito de direitos e pessoa em situação peculiar de desenvolvimento construída na esfera histórica e social. É sabido que as práticas voltadas para a infância no Brasil, foram envidadas pelas instituições religiosas, como atividade caritativa, passando pelo Estado que estabeleceu leis e políticas de atendimento em consonância com a Doutrina da Proteção Integral. Entre essas leis ressalta-se o Estatuto da Criança e do Adolescente, n. o 8.06911990. Os detalhes sobre o funcionamento do sistema socioeducativo foram explicitados no capítulo 02 da presente dissertação.

O que queremos destacar nesse momento, diz respeito às falas dos Pedagogos-OE's quando o assunto em questão é trazido à tona. De qualquer forma, não há, nas considerações tecidas, uma tentativa de ocultar ou maquiar as tensões imbricadas tanto no acompanhamento ao estudante adolescente autor de ato infracional, quanto aos desafios 
que esse atendimento impõe. Como se vê, existe desconhecimento e domínio dessa política para além da Liberdade Assistida com a qual os Pedagogos-OE's lidam no contexto da escola. Esse fato talvez seja uma influência das notícias veiculadas pela mídia brasileira e ao clamor pela diminuição da maioridade penal a fim de que os adolescentes sejam punidos como adultos em função da infração cometida (Abramovay, 2009).

Por outro lado, observam Yokoy de Souza e Lopes de Oliveira (2012: p. 291): "prover o direito à educação escolar no contexto das medidas socioeducativas implica a necessidade de implementar ações intersetoriais, envolvendo parcerias e contrapartidas para as quais o sistema de garantia de direitos, muitas vezes, não está preparado".

Alguns pormenores chamam a atenção nas considerações tecidas pelos PedagogosOE's e que necessitam ser pontuadas. Entre eles, está a discriminação quanto aos estudantes adolescentes que estão em cumprimento de medida socioeducativa. Abramovay (2009), ao discutir sobre a violência e convivência nas escolas públicas do Distrito Federal coordenou uma equipe de pesquisadores, com o objetivo de desvendar as tramas e segredos que perpassam as relações entre os atores escolares: estudantes, professores, membros da direção e servidores.

Entre os temas investigados o preconceito e a discriminação foram um dos abordados e se mostrou que os atos considerados violentos envolvem a intolerância de gênero, expressão sexual, desigualdade socioeconômica: pobreza, aparência e origem regional. A autora explica, todavia, que o preconceito leva em conta a crença preconcebida relacionada a atributos e qualidades a partir das características dos indivíduos. A discriminação, por sua vez, está relacionada a comportamentos e tratamento diferenciados de pessoas. Geralmente a discriminação vem acompanhada de preconceito (Abramovay (2009, p. 188).

Porém, a pesquisa citada acima não discrimina, nas entrevistas realizadas, os professores dos OE, por exemplo, mas denomina a todos como professores. Quando perguntados sobre que tipo de pessoas não gostariam de ter como alunos, 16,8\% dos entrevistados responderam que não gostariam de receber pessoas que já tinham sido presas, não especificando, portanto, se esse percentual se referia à Socioeducação. Na verdade, é preciso considerar que a Liberdade Assistida, é medida socioeducativa voltada para a promoção da reinserção social de adolescentes e jovens autores de atos infracionais.

É importante destacar também que as medidas socioeducativas são de natureza tanto jurídica quanto impositiva. Seu sentido, contudo, é de (re) educação. Curiosamente, já naquela época, 2009, os professores fizeram as mesmas narrativas de ausência de apoio por parte de órgãos públicos ao atendimento desses estudantes na escola. Isso se vê na fala dos Pedagogos-OE's nos dias atuais: 
pra mim, eu vejo o seguinte, é como se fosse um depósito... não vejo acompanhamento por parte de ninguém, de ninguém... o juiz determina que o menino esteja estudando e ele vem pra aqui pra escola como se aqui tivesse o poder de transformar (Pedagogo-OE D).

Tais fatos, como se vê, denotam a insegurança por parte dos educadores no atendimento de estudantes em LA. Abramovay (2009) conclui, apontando o estereótipo da marginalidade como sendo o grande responsável pelo preconceito e discriminação no presente tema. A nosso ver, e os próprios colegas Pedagogos-OE's declaram, é preciso investir em formação em Socioeducação para os profissionais que atuam nas escolas.

Além disso, apontam Yokoy de Souza e Lopes de Oliveira (2012, p. 291): "O afastamento entre instituições de atendimento, escolas e famílias viola as diretrizes do ECA e compromete o sucesso das medidas atribuídas ao adolescente autor de ato ". Complementam ainda que a própria condição infracional se constitui "condição peculiar de desenvolvimento que, por isso mesmo, se converte em objeto privilegiado para a promoção de inclusão escolar" (p.292).

Quando enfatizam a pouca integração entre os profissionais e órgãos envolvidos no processo de socioeducação, que vai desde o registro inicial do ato infracional até a determinação de cumprimento da penalidade imposta, a psicologia do desenvolvimento mostra o papel imprescindível da interação nas relações sociais, que nesse caso, envolve também instituições governamentais.

Acreditamos que um melhor entendimento e integração entre a rede socioeducativa, a saber, a educação, a saúde, a assistência social, dentre outros, trará inúmeros benefícios a todos os envolvidos, inclusive na formulação conjunta de políticas de formação de professores e outros profissionais que atuam no contexto das medidas socioeducativas. Torna-se necessário acabar com a cultura da mão única na socioeducação, como observamos nessas falas dos Pedagogos-OE's: "Você encaminha, mas não sabe o que vai acontecer... e a demora no atendimento? É todo um processo". (Momento de várias falas ao mesmo tempo). Corroborando com essa inquietude (Yokoy de Souza \& Lopes de Oliveira 2012, p.308) ressaltam "A falta dessa articulação pode dificultar que trajetórias de desenvolvimento marcadas pela exclusão se reorganizem". Cada sistema de garantia de direitos de crianças e adolescentes precisa rever seu papel na consecução dos objetivos de escolarização e desenvolvimento pleno desses adolescentes. 


\title{
Questão de pesquisa 03: Que tipo de conhecimento teórico/prático você considera importante para contribuir com seu trabalho junto aos jovens no contexto da Socioeducação?
}

$\mathrm{Na}$ questão anterior procuramos conhecer até que ponto os profissionais do Serviço de Orientação Educacional entendem sobre a Socioeducação, principalmente, para além da LA, que é com o que lidamos na escola pública regular. As respostas trouxeram várias vertentes sobre o conceito e mostrou mais entraves do que concepções. Então, partimos assim para um complemento sobre a discussão, na qual procuramos saber então, qual a formação adequada ou necessária para lidar com o dia a dia junto ao atendimento do estudante adolescente inserido no contexto escolar da Socioeducação. As manifestações mostram, não apenas a necessidade de formação na área, mas sobretudo a carência de cursos mais específicos e que atendam às necessidades de atuação como PedagogoOrientador Educacional e por que não dizer, aos demais profissionais no contexto da escola. Senão, vejamos:

\begin{abstract}
“Eu não tinha capacitação em orientação sexual... tinha formação acadêmica... técnicas de trabalho, nem de relações humanas... fui correr atrás e me capacitar... temas contemporâneos da educação...na socioeducação eu não consegui fazer (Pedagogo-OE C).

Os cursos são sempre os mesmos e nunca a gente foi beneficiado por um curso sobre a Socioeducação (Pedagogo-OE A).
\end{abstract}

\section{Análise e discussão da questão 03}

O indicador que percebemos nessa questão diz respeito à Socioeducação, teoria e prática no contexto da escola. Quase que unanimemente, os Pedagogos-OE's assumem a necessidade de formação no assunto das medidas socioeducativas como sendo imprescindível para uma melhoria no atendimento aos estudantes adolescentes em cumprimento de LA. Por outro lado, atribuem a ausência dessa formação apenas à da Escola de Aperfeiçoamento dos Profissionais de Educação (EAPE). "Socioeducação... eu acho que nunca foi ofertado pela EAPE. São temas contemporâneos da educação e dizem 
respeito ao trabalho da gente. Eu não posso dizer que a SEEDF não promova os cursos, mas não em Socioeducação". (Pedagogo-OE B).

A Secretaria de Estado de Educação do Distrito Federal oferece formação aos profissionais da educação, qual seja, docentes, pedagogos, psicólogos, auxiliares de educação, merendeiras, entre outros, na Escola de Aperfeiçoamento dos Profissionais de Educação - EAPE. A oferta de cursos é semestrallanual. Os temas são diversificados. Porém nenhum deles é voltado à pós-graduação. Aos Pedagogos-OE's fala-se muito de sexualidade, mediação de conflitos, gênero e diversidade.

Cremos, porém, que as discussões afetas à socioeducação não se resumem à formação dos professores e Pedagogos-OE's fora dos muros das escolas. O espaço de Coordenação Pedagógica dos mesmos, ocorridas semanalmente em diversas esferas, ou seja, tanto nos encontros coletivos como naqueles por área, são, por definição do Regimento Escolar das Escolas Públicas do Distrito Federal (SEEDF, 2015), espaços de formação constante do corpo escolar, qual seja: "A Coordenação Pedagógica constitui-se em um espaço-tempo de reflexões sobre os processos pedagógicos de ensino e de aprendizagem e formação continuada, tendo por finalidade planejar, orientar e acompanhar as atividades didático-pedagógicas, a fim de dar suporte ao Projeto Político Pedagógico" (artigo 119).

A formação adequada torna-se pertinente, na medida em que permite a construção de um fazer pedagógico dinâmico, inovador e reflexivo das práticas escolares com adolescentes que cumprem medidas socioeducativas. Contribui ainda para o enfrentamento da violência capaz de favorecer o desenvolvimento comunitário, fomento da cultura de paz e a aprendizagem dos valores de igualdade, justiça social, pluralidade cultural e de ideias, respeito mútuo à dignidade da pessoa humana, relações de solidariedade, tolerância e reconhecimento da singularidade do outro (Yokoy de Souza \& Lopes de Oliveira, 2012).

A Escola Nacional de Socioeducação (ENS) foi criada com o objetivo precípuo de atuar na formação continuada dos diferentes profissionais, em nível nacional, que, direta ou indiretamente, atuam no Sistema Nacional de Atendimento Socioeducativo (SINASE Resolução do Conanda n. ㅇ 11912006 e a Lei Federal n. o 12.594\2012). Dessa forma, profissionais, equipes técnicas, gestores e demais atores envolvidos neste setor, tem a oportunidade de, além de fundamentar suas práticas, proceder a troca de experiências, assim como aprimorar instrumentos de trabalho, com foco, sobretudo no adolescente autor de ato infracional, ou seja, adquirir conhecimentos, habilidades e atitudes em consonância com a legislação em vigor.

A ENS tem como pilares necessários para a efetivação das políticas públicas de atendimento aos adolescentes que cumprem medida socioeducativa, estabelecido assim 
pelo ECA e reguladas pelo próprio SINASE. Nesse sentido, os debates para criação da Escola foram iniciados em 2013 e ela está vinculada à Coordenação Geral do SINASE da Secretaria de Direitos Humanos da Presidência da República, cuja gestão é realizada em conjunto com o Conselho Nacional dos Direitos da Criança e do Adolescente, CONANDA e Fórum Nacional de Dirigentes Governamentais de Entidades Executoras de Políticas de Promoção e Defesa dos Direitos da Criança e do Adolescente (FONACRIAD).

A Universidade de Brasília também é outro espaço apropriado para formação em Socioeducação, por meio do Centro de Estudos Avançados de Governo e Administração. É responsável pelo gerenciamento dos cursos ofertados: conteúdo, plataforma virtual, entre outros, através de convênio. Há, atualmente um amplo material escrito disponível sobre essa temática.

O Centro de Defesa da Criança e do Adolescente (CEDECA), também é uma instituição com atuação em nível nacional que atua, entre outras coisas, no fortalecimento do Sistema Socioeducativo e, nesse sentido, oferece cursos de formação, produção de conhecimento através de publicações, e também na defesa jurídico social voltada para os mesmos fins. $O$ Cedeca oferece ainda outros cursos voltados para assuntos concernentes à criança e ao adolescente em geral e nesse sentido, é uma instituição disponível para formação em diversos temas, à disposição dos profissionais da educação.

A realidade mostrada nas falas dos Pedagogos-OE's quando denunciam a inexistência de formação ofertado especificamente pela EAPE em Socioeducação, mostra o pouco alcance, talvez ineficácia no processo de divulgação dos cursos aos profissionais que atuam na rede socioeducativa no contexto da escola. Por outro lado, esse mesmo profissional reconhece que precisa avançar na formação pessoal para além da EAPE:

Eu acho que a gente fica muito esperando pela EAPE... acomodamos... Se a EAPE não oferecer nada, a sensação que dá é a de ninguém vai atrás de nada. Tem que ir atrás de outras coisas, porque a EAPE é muito fraca nos cursos pra OE. Eu vejo a academia muito distante da gente. A UnB nunca ofertou nada... quando eu entrei na rede havia os encontros com os $O E$ por Regionais e foi a melhor época, eu aprendi muito. Depois foi morrendo, foi acabando... (Pedagogo-OE D).

Na direção da psicologia histórico-cultural, Santana e Lopes de Oliveira (2012, p. 67) afirmam o seguinte: 
Visto como espaço privilegiado para o desenvolvimento adulto, o processo de formação de professores configura, por sua vez, um lócus no qual várias questões de natureza ética estão implicadas. A formação docente agrega e coordena um conjunto heterogêneo e, por vezes contraditório, de vozes de natureza cultural, social, histórica, legal, institucional e pessoal.

Essas considerações mostram a importância da formação constante como benéfica ao desenvolvimento dos educadores tornando-os assim, mediadores nos processos educacionais e, ao mesmo tempo, "canalizam e orientam o desenvolvimento pessoal dos sujeitos em formação" (p. 67). Os espaços de formação possibilitam também a troca de saberes culturais e valores construídos reciprocamente.

\section{Questão de pesquisa 04: Qual a sua percepção da compreensão que a escola onde atua tem da Socioeducação? Como o Pedagogo-OE e a respectiva instituição de ensino pesquisada compreendem o papel da escola na rede socioeducativa?}

Em experiências que tivemos com professores e diretores escolares até em conversas informais como forma de aproximação ao fenômeno, vemos nas falas, sentimentos de negatividade em relação ao um futuro promissor de estudantes adolescentes em cumprimento de medida socioeducativa. O preconceito e a discriminação são as reações mais comuns, acrescidos de dúvidas, medo e descontentamento com o atual sistema socioeducativo. O que não se mostra diferente com os Pedagogos-OE's:

A discriminação, por causa da falta de informação, preconceito, curiosidade sobre o que o menino aprontou.... Depois tem que mandar relatório. Os professores não se acham capacitados ou tem medo dos alunos. Há o receio. No geral, o professor pensa: eu não vou mexer com esse aluno. Nós como OE aqui na escola evitamos falar para os professores quando há aluno em $L A$, a não ser que aconteça algo muito grave. Há uma marcação. (Pedagogo-OE A).

Há a possibilidade de o aluno ter uma marcação. Primeiro porque 0 olhar de todo mundo muda. (Pedagogo-OE C). 
Eu não vejo a escola preparada para receber aluno em $L A$. Que poder nós temos aqui dentro de fazer essa transformação? A escola é limitada. Às vezes o aluno não é um menino ruim, apenas foi pego em um momento ruim. (Pedagogo-OE D).

Em 18 anos de SEEDF eu só tive um único caso de aluno em LA. Mas há muita perseguição. Pra algumas pessoas funciona como 0 Bolsonaro diz: bandido bom é bandido morto. Mesmo que isso não seja expresso em palavras, há esse sentimento. Ou seja, menor infrator é fora da escola. Na verdade, existe na escola uma cultura da transferência. Então se acontece um problema com esse aluno na escola, ele é expulso. (Pedagogo-OE B).

\section{Análise e discussão da questão 04}

Conforme vimos na questão anterior, a temática da socioeducação no contexto da escola é delicada e complexa. Ainda que essa questão tenha gerado impressões aparentemente similares à anterior, percebemos aqui mais um indicador que corrobora as afirmações ou colocações ditas em tempo anterior: qual o papel da escola na vida do adolescente autor de ato infracional. Percebemos, na subjetividade produzida pelo efeito que as relações entre os sujeitos podem provocar ou gerar, na medida em que são construídos sentimentos de medo em torno do desconhecido sobre a percepção do outro. Sem perder de vista o caráter histórico-cultural como fundamento desse trabalho, González Rey observa que:

Tem-se então uma trajetória rumo a um sujeito que transita por um emaranhado complexo de identificações que se metamorfoseiam em meio a categorias de indicador cada vez mais numerosas e variadas, expostas a uma quantidade de informações nunca vista antes e colocadas diante de uma enorme gama de valores e crenças.

Nessa direção, percebe-se que ao mesmo tempo em que defende a nãodiscriminação do estudante autor de ato infracional no ambiente escolar, em alguns momentos vemos traços de exclusão e temor em relação ao outro: 
Se o aluno foi pego mexendo com droga, o que que ele vai fazer dentro da escola a não ser continuar mexendo com droga? Então o preconceito é difícil de ser desmistificado, porque você sempre pensa que ele fez o pior (Pedagogo-OE D).

Aparecem aqui as dimensões simbólicas, afetivas, sociais e simbólicas manifestas na subjetividade humana. Os humanos são sujeitos ativos no mundo. Sua subjetividade se constitui justamente no contato com o outro, ou seja, no bojo das relações humanas em interação com fatores internos e externos a si, em um processo dialético constante (Alves \& Pedroza, 2016).

Não se trata aqui, todavia, de julgamento das atitudes dos colegas Pedagogos-OE's, já que, os significados emergem e afetam o sujeito a partir da sua interação com o mundo. Que ferramentas a escola tem utilizado para regular e transformar as relações que nela ocorrem? (Cubero \& Luque, 2004). Vigotski afirmou que os instrumentos utilizados na mediação humana afetam ou dão forma às atividades humanas. As relações são pautadas na linguagem, nos símbolos e sentidos que damos às experiências vivenciadas. $O$ comportamento influi sobre a natureza e vice e versa.

A respeito da interação do papel ativo do sujeito no seu processo de desenvolvimento, além das interações com o contexto sociocultural, Madureira e Branco (2005, p. 91) ponderam "que seus membros estão em constante processo de recriação e reinterpretação de informações, conceitos e significados".

Por outro lado, não pudemos deixar de perceber o efeito negativo e que em muitos casos pode representara a ruptura do estudante adolescente com a escola. Referimo-nos às dimensões preconceituosas e discriminatórias aplicadas àqueles que possuem registro na socioeducação. No imaginário de alguns educadores, uma vez autor de ato infracional, sempre autor.

Vale sublinhar, contudo, que sempre que focamos nossas práticas no espaço escolar em atos de preconceito e discriminação, estamos explicitando, ainda que sem palavras, os mesmos processos exclusivos presentes na nossa sociedade (Madureira \& Abreu Branco, 2012). Estamos reproduzindo as fronteiras simbólicas contrárias ao respeito à diversidade. E olha que o Brasil é festejado pelo caráter cordial e conciliador de seu povo. As autoras citadas observam ainda que o preconceito presente nas relações estabelecidas no cotidiano tem suas raízes ou origens no "universo simbólico da cultura coletiva, nas relações de poder" (p. 128). No fim das contas, a discriminação existe em função do preconceito velado ou não. Ambos estão assim, vinculados. 
O papel da escola como instituição social que é, entre suas muitas funções, está o de promover espaços que propiciem discussão e problematização sobre a temática do enraizamento afetivo provocado pela trajetória histórico-cultural das interações humanas. Sendo essa a principal forma de trazer à tona temas para além da aprendizagem de conteúdos formais, os quais podem contribuir para a desconstrução das práticas discriminatórias dentro e fora do ambiente escolar.

\section{Questão de pesquisa 05: De que maneira é feito o acolhimento e acompanhamento do estudante adolescente que esteja em cumprimento de medida de Liberdade \\ Assistida?}

Na escola que eu sou não tem aluno em LA, mas geralmente ele é passado pra $O E$, porque eles partem do princípio que a OE teria toda essa capacitação profissional de fazer esse atendimento. (Pedagogo-OE C).

O lance do sigilo é engraçado. Se você fala tem o rótulo. Se acontece algo, te perguntam porque não chamou a polícia, porque não fiz isso ou aquilo. (Pedagogo-OE D).

Na minha escola não tem aluno em LA. (Pedagogo-OE C).

\section{Análise e discussão da questão 05}

A escolarização aos adolescentes que cumprem medidas socioeducativas seja em LA, semiliberdade ou privação de liberdade é uma determinação prevista tanto na Constituição Federativa do Brasil, de 1988 quanto no ECA. Essa determinação demanda a intersetorialidade da rede de atendimento socioeducativo em que se insere a escola, das ações que envolvam parcerias em função da garantia de direitos dos estudantes adolescente, implicando na necessidade de aproximação e acolhimento.

Brancalhão, 2003, (citado por Yokoy de Souza \& Lopes de Oliveira, 2012) mostra que: "o traço pedagógico das medidas socioeducativas ainda é muito tímido e incapaz de assegurar uma reflexão pedagógica mais aprofundada nas unidades socioeducativas" (p.292). 
Acolher o adolescente em cumprimento de LA no universo da escola, implica, entre outras questões, cumprir a tarefa de promover a aprendizagem e contribuir para o seu desenvolvimento global como humano, seja nos âmbitos cultural, interpessoal e subjetivo.

Refletindo sobre as falas dos Pedagogos-OE's, o indicador percebido nesse item 05 diz respeito à escola como espaço de acolhimento. Nesse ponto, Cubero e Luque (2000) enfatizam que Vigotski considerou a educação como sendo a responsável pelo processo de humanização. Ao passo que a escola é seu 'laboratório' principal, pois permite o estudo aprofundado da dimensão cultural desse processo. Na mesma direção, os autores nomeiam a escola como "instituição cultural na qual se produzam aprendizagens" (p. 94). Na perspectiva histórico cultural as aprendizagens significativas adquiridas no decurso de vida, não são vivenciadas ou entendidas no plano apenas individual, mas em processos de coconstrução e construção conjunta.

Acolher, para os Pedagogos-OE's colaboradores da pesquisa, requer uma articulação dentro da própria escola:

O acolhimento passa pela secretaria, depois direção e só depois é que vem para nós. Em último caso é que a gente fala para o professor. Porque e se acontece um pepino, todo mundo resolve junto. A escola tem que se posicionar. Fazer conselho extraordinário, chamar a família, e depois se decide o que fazer se dá ou não uma chance ou não. A decisão é em conjunto. Acho bacana. Aqui se faz assim. (Pedagogo-OE A).

De outro lado, acolher também pode significar a contrapartida por parte do aluno, como se vê nesse comentário:

Quando o aluno passa pra dentro dos muros da escola ele é nosso aluno, mas se você quer prejudicar a escola, aí é diferente. $\mathrm{Na}$ verdade, a EJA é diferente se o aluno é de periferia, negro e tudo o mais, tudo é mais difícil. Ao pais de aluno de Eja não vem na escola. É tudo diferente. (Pedagogo-OE D).

Entretanto, ao mesmo tempo tem-se o cuidado pelo sigilo das informações sobre a situação do estudante adolescente em cumprimento de LA, assim como a preocupação, por parte de alguns de proteger o sujeito de preconceito e discriminação no ambiente escolar, vindo não apenas do professor, que quer de imediato saber qual ato infracional foi cometido, como também dos próprios colegas de turma. 
Ser um estudante em cumprimento de LA muitas vezes traz um valor simbólico entre o grupo social dentro e fora da escola, bem como pressupõe, para outros, motivo de empoderamento diante daqueles que podem representar perigo.

Percebemos também, na consulta ao Projeto Político Pedagógico (PPP) das instituições escolares participantes da pesquisa, que nenhum desses documentos aborda a temática da socioeducação, seja a título de prevenção ao ato infracional, seja como projeto de acolhimento ou proposta de atividades aos estudantes que são ali matriculados.

Entendemos que, de certa forma, preparar a escola, seus alunos e famílias para o atendimento de estudantes em LA pressupõe uma articulação prévia, com abertura ao diálogo em conjunto, a fim de que não sejam pegos de surpresa, quando própria matrícula traz em si um desdobramento mais específico. A esse respeito, Vieira e Lopes de Oliveira (2013) concluem que:

O maior desafio das políticas de atendimento ao adolescente em conflito com a lei é construir um sistema educativo no qual as ações pedagógicas articulem os diversos recursos sociais e comunitários para o oferecimento de atenção integral e especializada, direito de crianças e adolescentes previsto no estatuto da Criança e do Adolescente (ECA), e ratificado no marco da Convenção sobre os Diretos da Criança.

Constatamos, no âmbito do Regimento Escolar da Rede Pública de Ensino do Distrito Federal, de 2015, nos artigos 410 a 413 e parágrafo único, um importante avanço em direção à temática, pois trata das políticas públicas para escolarização nas medidas socioeducativas e no sistema cautelar, assunto que as edições anteriores do Regimento não explanavam. Então, cabe às escolas públicas a responsabilidade de inserir esse contexto em seu PPP.

Em contrapartida, vemos a necessidade de o Pedagogo-OE de revisitar os estudos sobre desenvolvimento adolescente e sua evolução histórica. Dessa forma, evita-se contribuir para a cultura dos mitos sobre a adolescência, assim como sua imagem negativa e distorcida tão propalada no Brasil nos dias atuais. 


\section{Questão de pesquisa 06: Quais as contribuições da instituição de ensino na inclusão de estudantes em medida de LA?}

é dar a oportunidade de vivenciar outras experiências para além da situação de vulnerabilidade. (Pedagogo-OE C).

$O$ adolescente tem a própria cultura, sua maneira de vestir. O olhar diferenciado, é necessário. Não existe no PPP menção à Socioeducação. É preciso evitar que o adolescente chegue na Socioeducação. Nós tentamos fazer uma pesquisa da cultura do aluno: vocabulário, a roupa, as letras e outras coisas, mas sem estar no PPP. Geralmente a escola tende a negar a cultura do adolescente. É a negação da cultura jovem. A universidade peca porque não é oferecido capacitação ao professor. Espero que essa pesquisa seja divulgada entre os Pedagogos-OE's da nossa rede de ensino. (Pedagogo-OE B).

Falta pegarmos assuntos que nos inquietam pra discutir nas coordenações. Voltar os encontros temáticos. As demandas que tem na escola exigem cada vez mais de nós. (Pedagogo-OE C).

\section{Análise e discussão da questão 06}

Se na questão anterior falamos sobre acolhimento, nesta abordamos quais as políticas de inclusão adotadas pelas escolas públicas em relação ao adolescente em cumprimento de medida socioeducativa. $O$ indicador que consideramos é: a inclusão como um direito de todos no cenário da escola.

A história de luta das pessoas com deficiência, cunhou, ao longo dos anos, o termo inclusão para se referir a esse público alvo. Entretanto, temos discutido, inclusive nas Coordenações Coletivas Semanais dos Pedagogos-OE's, a relevância de considerar, no ambiente escolar a todos os estudantes nos programas inclusivos. Dessa forma, alunos com necessidades especiais, negros, brancos, pardos, magros, gordos, com identidade de gênero, ricos e pobres, entre outros precisam ser acolhidos e incluídos nas atividades do cotidiano escolástico. Vejamos o que diz esse educador: 
Oportunizar. Fazer atividades diversificadas: exposições, feiras de profissão, incluir os alunos da EJA e o aluno que está em $L A$. Os meninos não gostam de ser tocados. O retrato de pai muda 0 comportamento. Então é preciso tratar diferente. É preciso parar de discriminar. Aonde o aluno mora é melhor lugar, aceitar o contexto do aluno é o melhor a fazer. A forma de receber muda tudo. Mas eu só ajudo quem quer ajuda. Se não quer... em ser hipócrita. Nós colhemos os frutos anos depois. (Pedagogo-OE D).

Curiosamente como dissemos anteriormente, ao mesmo tempo em que a escola procura acolher e incluir, impõe condições: se andar na linha, digamos assim, tudo, senão... tem transferência compulsória, tem marcação, tem discriminação, tem expulsão. De outra forma, praticamente em todas a considerações feitas pelos Pedagogos-OE's, todos fazem questão de enfatizar características de sua função na escolha de forma bem peculiar: facilitador da aprendizagem, está na escola para ajudar, orientar (termo bastante citado nas duas primeiras questões), aconselhar, acolher, mediar, colocar-se no lugar do outro, ser altero.

Vemos também, de forma sutil, que em alguns momentos, essa maneira de agir, por vezes conciliadora, ou servindo de ponte, entre os estudantes e professores, diretores pode ser mal-entendida, como se vê nessas colocações:

Outra coisa, na pior das hipóteses, o risco é nosso... não vai ser o professor, nem o secretário, nem o diretor... (Pedagogo-OE C).

Acham que nós queremos passar a mão na cabeça dos alunos. (Pedagogo-OE B).

Afora essas questões, os processos subjetivos se fazem notar, de forma clara nas narrativas, que cada um tem, com nitidez, ciência da sua função no ambiente escolar e assim, trabalham para a consecução dos objetivos da escola e do Serviço de Orientação Educacional nas suas práticas cotidianas, e por que não dizer, na defesa dos direitos de crianças e adolescentes. Observa-se um compromisso pessoal e social com a mediação do sucesso escolar do estudante adolescente e suas famílias. Da mesma forma, procura-se dar o máximo de suporte ao trabalho dos professores, direção e demais atores do ambiente escolar. 
Corroborando sobre a função da Orientação Educacional e suas práticas cotidianas, ainda que, em dada situação ou momento de inquietação sobre o fazer educação em conjunto com o outro, (Grispun, 2012, p.194) exalta a grandeza que o espaço escolar representa para o Orientador Educacional, ao tempo em que diz:

Num desenho imaginário, o cotidiano seria uma figura tecida com vários fios e cores e tonalidades múltiplas que vão se entrelaçando de formas diferenciadas. Nesse cotidiano, lança-se mão de normas, regras, ações já previstas ou legitimadas pelas normas institucionais ou de estratégias que, como diz Coreau, são ações de quem tem o poder, ou um poder instituído para utilizá-las.

Ao mesmo tempo em que influenciam os Pedagogos-OE's são influenciados pelo meio, representado aqui não apenas por aqueles que convivem dentro dos muros da escola, mas também pela comunidade circunvizinha, pela mídia, pelas políticas sociais e de governo, entre outros, mas também pelos seus processos de subjetivação, que se refletem na sua maneira de ser, pensar e agir. Igualmente acontece da mesma forma com os demais atores escolares. Esse sentido de ver e viver a vida e o trabalho não podem ser negligenciados.

Muito embora o principal objetivo da escola, dito isso de todas as demais instituições de ensino, como colégios em geral e universidades, não se pode controlar tudo o que acontece em seu interior, isto porque, ao pretender formar um cidadão crítico e consciente, sua maior preocupação é com o sujeito. Que, "ao mesmo tempo é aluno, é pessoa, é cidadão e se forma no seu processo de escolarização" (Grispun, 2012: p, 195).

\section{A Oficina com os estudantes adolescentes participantes da pesquisa}

A seguir, apresentamos na íntegra o conteúdo das letras dos hip hop compostos pelos estudantes adolescentes durante a oficina na perspectiva do Teatro do Oprimido, de Augusto Boal:

\section{Grupo I}

A vida do crime compensa não, 
Ou é cadeia ou é caixão.

Tudo nela parece um mar cor de rosa,

Mas o bang é louco e você não se importa.

A escola faz parte do nosso futuro, nada na vida é fácil,

Tudo é duro.

Nossa cultura praticamos na quebrada,

Curto um som de lei com a rapaziada. ( $\mathrm{R}$ - 17 anos, E - 16 anos, $\mathrm{Y}$ 16 anos, CV - 16 anos).

\section{Grupo II}

Chego na escola querendo estudar. Aí chega o parceiro chamando pra bagunçar. Mano, vou te falar, agora eu não vou, vou te dar uma ideia sobre educação: vamos ficar de boa, vamos estudar. Tá ligado que o futuro tem que melhorar, ajudar a coroa que batalhou pra nos criar. Minha mãe sempre dizia pra na rua não andar, perigo é muito, tem em todo lugar. Nossa cultura é assim, somos pretos favelados, discriminados pelos vermes fardados. Agora vou te falar, os estudos tem que terminar, ter uma vida boa, pro futuro melhorar. (GR - 14 anos, D - 15 anos, LN - 14 anos, RG - 15 anos).

\section{Grupo III}

Título - O perigo universal

Assaltos na porta da escola,

Morte dentro da escola,

Brigas entre colegas,

O tráfico de drogas nas pracinhas e os assaltos nas comunidades. (JV - 16 anos, FV - 17 anos, WD - 17 anos, RG - 15 anos, MC 16 anos). 


\section{Análise e discussão da Oficina de Jogos Teatrais}

Em minha trajetória como Pedagoga-Orientadora Educacional na rede pública de ensino, meu contato mais longo, foi com jovens entre na faixa etária de 12 a 18 anos, salvo aqueles que fora da faixa etária na trajetória escolar, frequentavam a EJA ou algum tipo de aceleração da aprendizagem, como se denominou aqui no Distrito Federal.

Os momentos de maior alegria observados na escola, foi quando fazíamos juntos alguma atividade voltada para a cultura jovem. Outros assuntos ligados aos temas transversais também eram bastante apreciados, como Orientação Sexual e Orientação Profissional, mas aqueles voltados à cultura jovem batiam recordes de participação e nível de satisfação. Nesse sentido, a atividade trouxe ao olhar dos adolescentes que participaram da pesquisa, brilho no olhar e inspiração. Em princípio perguntaram se podiam falar a verdade sobre o que viam e o que pensavam da escola. Com o aval positivo, puseram-se a escrever e cantarolar.

Guimarães e Silva Jr. (2012, p. 84) ao dispor sobre a cultura jovem, dizem: "As identidades jovens são marcadas pelos espaços que frequentam, pelo lugar onde vivem, pelo contato com outros jovens. Modificam-se ao longo do tempo, incorporam novos elementos, enfim, movimentam-se". Essa observação mostra a importância da interação entre os sujeitos que o contexto proporciona na perspectiva histórico-cultural do desenvolvimento.

Um indicador pode ser ressaltado: o que mais preocupa e interessa aos jovens: diferentes olhares. O que vemos, nas falas dos adolescentes nada mais é do que a manifestação dos processos de significação e sentido que constituem a vida social dos jovens produzidos na sua percepção e vivência. Nessa direção, González Rey (2010, p.136) afirma: "a pessoa se expressa na produção de verdadeiros campos de sentido subjetivo caracterizados por sua elaboração pessoal, pela afetividade envolvida, pelos desdobramentos que a própria narrativa vai tomando, pela densidade e continuidade de sua expressão". Quando os adolescentes escrevem "Nossa cultura é assim, somos pretos favelados, discriminados pelos vermes fardados. Agora vou te falar, os estudos têm que terminar, ter uma vida boa, pro futuro melhorar", estão trazendo elementos do que veem, sentem e observam no seu cotidiano.

Independente de transitar no campo ou na cidade, a vivência do adolescente é perpassada pelas coisas do seu contexto, cujas trajetórias "são construídas em espaços com fronteiras móveis" (Guimarães \& Silva Jr., 2012, p. 105). Tais fronteiras são mediadas nas relações com o outro. A cultura manifestada nas suas percepções advém dos espaços sociais, entretanto, sua constituição é singular e se distingue do social. 
Chaves (2013) pondera que a violência tem uma dinâmica histórica e é algo que se reflete nas formas de vida dos jovens. Nesse sentido, a realidade constrói-se a partir do social. Nossa sociedade, ou não compreende ou culpa os jovens pelas mazelas do mundo. No cerne dos problemas sociais gerados pelos próprios humanos, crianças, adolescentes e jovens tem seus direitos civis e políticos alijados.

Por outro lado, embora conheçam e reconheçam os benefícios que a educação escolar proporciona, as frases trazem os registros do medo e preocupação com o futuro:

Mano, vou te falar, agora eu não vou, vou te dá uma ideia sobre educação: vamos ficar de boa, vamos estudar.

A escola faz parte do nosso futuro, nada na vida é fácil, tudo é duro.

Da mesma forma, relatam um cotidiano escolar sombrio e assustador: Assaltos na porta da escola, morte dentro da escola, brigas entre colegas, o tráfico de drogas nas pracinhas e os assaltos nas comunidades". E mais: A vida do crime compensa não, ou é cadeia ou é caixão".

A vivência e os valores familiares também merecem destaque na análise das falas: "Tá ligado que o futuro tem que melhorar, ajudar a coroa que batalhou pra nos criar. Minha mãe sempre dizia pra na rua não andar, perigo é muito, tem em todo lugar". A respeito do ambiente familiar e educação escolar: a interseção de dois cenários educacionais, Lacasa (2004) constata que as escolas, como instituições sociais, são consideradas como sendo de grande importância. Nesse sentido, familiares e as próprias crianças nutrem com relação a elas, grandes expectativas. Escola e família são, assim, "como os dois ambientes mais importantes de socialização" (p. 403).

Família e escola são constituídos a partir das dimensões sociais, culturais e históricas, as quais constroem mutuamente mediadas pelos instrumentos e ferramentas simbólicas e materiais. Foi o que apontou Vigotski em seus estudos sobre o desenvolvimento humano. Bronfenbrenner (citado Lacasa, 2004, p. 406) mostra que:

O mundo exterior tem um impacto considerável desde o momento em que a criança começa a relacionar-se com pessoas, grupos e instituições, cada uma das quais Ihe impõe suas perspectivas, suas recompensas e seus castigos, contribuindo, assim, para a formação de seus valores, de suas habilidades e de seus hábitos de conduta. 
De certa forma, o dia a dia do trabalho do Pedagogo-OE no contexto escolar é atravessado por todas essas realidades citadas pelos estudantes adolescentes nas letras dos hip hop construídos por eles. Essa realidade adentra o espaço físico do Serviço de Orientação Educacional, acreditamos que não apenas no Distrito Federal, mas em vários estados brasileiros. Entretanto, os projetos implementados, o acompanhamento dos estudantes e da família mostram que, mesmo que haja divergência entre o que é ensino na escola e na família e o que acontece na sociedade, como a propagação da violência, ainda há espaço para a promoção da cultura de paz dentro e fora da escola.

\section{Análise dos espaços de fala entre os Pedagogos-Orientadores Educacionais e os Estudantes Adolescentes no Ambiente Escolar}

O espaço de escuta preparado para ouvir os estudantes adolescentes que participaram da pesquisa não foi escolhido por acaso, pois sabíamos, e a nossa experiência escolar assim o dizia, que nem sempre querem se sentar e serem entrevistados por um adulto, principalmente quando esse encontro significa trazer à tona conflitos nos quais muitas vezes estão imersos ou mesmo para saber das suas impressões sobre a escola e as pessoas nela envolvidos.

Em busca não de respostas, mas de despertar sentidos na pesquisadora a partir do lugar de fala dos adolescentes, para quem a escola existe, escolhemos a metodologia do Teatro do Oprimido proposta por Boal, que mostra haver outras formas de se colocar ideias, expor as problemáticas políticas, econômicas e sociais, através da Árvore do Oprimido. Assim, a partir da imagem figurada em forma de árvore possibilitamos uma mediação, de modo que se expressassem, por meio da palavra, de sons ou imagens. Uma leitura histórico-cultural nos permite compreender esse processo mediado pelo teatro como uma construção de outras possibilidades de os jovens se expressarem, diferentes das maneiras adultas comumente propostas em salas de aula. Com poesia e ritmo, eles mostraram como têm vivido suas experiências com a escola, o preconceito, seus desejos e perspectivas.

Ao contrário do que possa parecer, os adolescentes têm clara a importância da escola para a sua construção pessoal como sujeito ativo nos espaços em que transita. Da mesma forma, mostram que não estão alheios aos perigos que a violência impõe a eles no transcurso de sua vida cotidiana e, em função disso, parecem clamar por uma escola livre de opressão, sem armas ou drogas, onde eles e suas famílias possam crescer e ser 'alguém', como eles mesmos dizem. 
Causa-nos estranheza que essa escola que as crianças, os adolescentes e os pais louvam como sendo a instituição social mais importante, permita o preconceito e a discriminação, aceite a exclusão de estudantes que a ela não se adaptarem ou que quebrarem as regras, construídas em resposta à voz de alguns (Pedagogos-OE's, professores, diretores e outros educadores), sem considerar a escola como espaço de fala também dos estudantes adolescentes, e, em muitos momentos, seja uma escola que represente um lugar onde há brigas, xingamentos, armas de fogo e mortes, um lugar onde a identidade adolescente é colocada em segundo plano ou mesmo desconsiderada, como é o caso de algumas instituições sociais, seja a escola ou não.

A paridade de participação dos estudantes adolescentes nas tramas que perpassam o cotidiano da escola requer uma abertura maior ao diálogo, coisa que Paulo Freire (1996) tanto apregoou. Promover a paridade de voz nos espaços escolares pressupõe um respeito ou mesmo o desrespeito ao princípio da igualdade de direitos, igualdade de deveres, igualdade de direito e deveres, reciprocidade, mérito, valorização do outro, qualidade do ensino, diálogo, participação, pluralismo, acolhimento, abertura aos questionamentos, com papéis definidos, curiosidade, utopia, valorização do professor e do estudante (Schilling, 2014).

Repetir que a escola é, muitas vezes, palco de atitudes violentas e antissociais é algo que ouvimos com certa frequência por parte tanto de quem está diretamente envolvido nela, bem como da opinião pública e mídia em geral. Entretanto, imaginar uma escola "muito além do pânico cotidiano que nos cerca, imaginar, talvez, uma escola sem violência, uma escola justa" (Schilling, 2014, p. 15) é algo que devemos continuamente perseguir.

Os adolescentes nos mostram uma escola pluralista no sentido de que abriga, entre seus muros, diversas formas de pensar, de ser e de agir. Essa é a escola imaginada pelos estudantes adolescentes, qual seja, uma escola que permita o acesso livre aos seus sujeitos cidadãos e a permanência por livre vontade e satisfação; escola que permita o acesso a um conhecimento de qualidade; escola que conheça e reconheça a identidade de seus alunos e os respeite como sujeitos ativos e agentes de seu próprio desenvolvimento.

Embora a socioeducação carregue em si o sentido jurídico e impositivo de reparação de dano aplicada de acordo com a infração cometida, Schilling (2000) indaga: "só há justiça quando há justiça restaurativa? Como lidar, no cotidiano escolar, com o "talvez", com as dissonâncias e encontros entre os alunos e os professores que lá estão, com a forte demanda detectada de igualdade, respeito, reciprocidade e diálogo"? (p. 124).

Essas não são perguntas para se responder neste ponto desta dissertação de mestrado, mas no sentido de trazer reflexões sobre quais demandas a socioeducação traz aos Pedagogos-Orientadores Educacionais e aos professores e educadores que dela 
participam seja dentro ou fora do contexto escolar aberto ou para as escolas que fazem parte do sistema da socioeducação em regime de restrição de liberdade. Tais práticas tem o poder de promover efeitos benéficos para os estudantes, professores, Pedagogos-OE's e diretores de escolas públicas e privadas, para que promovam também transformações mútuas nos modos de ser, agir e se relacionar, com possibilidades de educar e compreender cada vez mais a escola. 


\section{VII - CONSIDERAÇÕES FINAIS}

Violência significa: 1) tudo o que age usando a força para ir contra a natureza de algum ser (é desnaturar); 2) todo ato de força contra a espontaneidade, a vontade e a liberdade de alguém (é

coagir, constranger, torturar, brutalizar; 3) ato ou violação da natureza de alguém ou de alguma coisa valorizada positivamente por uma sociedade (é violar); 4) todo ato de transgressão contra o que alguém ou uma sociedade define como justo e como um direito

(Chaui, 1999, p. 5)

Ao propor as discussões sobre O Pedagogo-Orientador Educacional no Acolhimento e Acompanhamento de Adolescentes em Medida Socioeducativa, definimos como objetivo geral: Analisar a atuação do Pedagogo-Orientador Educacional junto aos estudantes em cumprimento de medida socioeducativa, a partir do qual construímos os objetivos específicos, quais sejam: Identificar e analisar o acolhimento e acompanhamento aos estudantes em cumprimento de medida de Liberdade Assistida em uma escola da Rede Pública de Ensino do Distrito Federal; Conhecer a participação do Pedagogo-Orientador Educacional em relação aos estudantes em cumprimento de medida socioeducativa na referida escola.

A fundamentação teórica sobre os temas aqui levantados, especificadamente, Orientação Educacional e Psicologia do Desenvolvimento, atrelado à construção de informações feitas com os participantes da pesquisa, nos permite fazer alguns apontamentos a partir das categorias de indicadores percebidas durante o trabalho de campo, quais sejam: 1) posição de reflexão e crítica ao trabalho do Pedagogo-OE no ambiente escolar aparecem inseparáveis; 2) empatia e caráter de orientação estudantil e da família; 3) O que cada um é e o que não é na sua função na escola; 4) posição pessoal frente aos desafios no ambiente escolar; 5) reconhecimento da incompletude das políticas públicas na rede socioeducativa; 6) Socioeducação, teoria e prática no contexto da escola; 7) Qual o papel da escola na vida do adolescente autor de ato infracional; 8) Escola como espaço de acolhimento; 9)a inclusão como um direito de todos no cenário da escola; 10) O que mais preocupa e interessa aos jovens: diferentes olhares.

Assim sendo, além de tecer algumas considerações finais emergidas nas análises e discussões, indicamos possíveis contribuições da Psicologia do Desenvolvimento à prática 
do Pedagogo-OE no contexto da escola. Da mesma forma, procuramos fazer alguns apontamentos que respondam às angústias que perpassam a atuação desse profissional da educação no seu ambiente de trabalho e na sua formação.

Durante o fórum de debate com os Pedagogos-OE's foi possível perceber o caráter inegável de importância da escola na vida do indivíduo no seu ciclo de desenvolvimento humano. Percebeu-se também que, cada um na sua instituição de origem, juntamente com os demais membros do corpo escolar, persiste na busca de soluções pedagógicas diversificadas e criativas, capazes de impedir a evasão escolar do adolescente em cumprimento de LA, assim como de promover um bom convívio escolar e a educação em e para os direitos humanos.

A pesquisa mostrou que não há uma padronização na forma como as escolas acolhem os adolescentes para elas encaminhados e que estão em situação peculiar de desenvolvimento ao cumprir medida socioeducativa de Liberdade Assistida. Talvez fosse o caso de discutir a necessidade não de padronizar ou uniformizar as ações dos PedagogosOE's na rede púbica do DF, mas no sentido de nortear a prática de um trabalho reflexivo e crítico, de forma a contribuir para um melhor acolhimento ao estudante adolescente em cumprimento de medida socioeducativa.

A Psicologia do Desenvolvimento, por sua vez, pode ser útil à prática do Pedagogo-OE na rede socioeducativa no contexto da escola: 1) A partir do entendimento do comportamento adolescente durante o seu desenvolvimento, compreendendo a adolescência como uma construção sociocultural peculiar de desenvolvimento psicofisiológico, é possível reduzir os atritos causados pelo rótulo de rebeldia e desafio ao educador ou ao adulto; 2) conforme aponta Schraml (1977, p. XVI) ao compreender como se dá o desenvolvimento da personalidade humana e "da pessoa, da criança e do jovem" e a percepção do seu próprio desenvolvimento em relação aos estudantes, torna-se possível facilitar os procedimentos que contribuam para o avanço das suas capacidades de forma integral; 3) Sendo o Pedagogo-OE um representante da comunidade e de sua cultura, também é responsável pelos processos de socialização e formação do sujeito no próprio meio de desenvolvimento do qual faz parte, sendo esse um dos fatores essenciais no fenômeno do desenvolvimento na perspectiva histórico-cultural proposta por Vigotski.

Quando o assunto é Socioeducação, penso que o Pedagogo-OE, no Distrito Federal, pode, em conjunto tanto com os diretores escolares e em parceria com as universidades, entre elas, a Universidade de Brasília, promover espaço de discussão permanente com o corpo escolar, incluindo os estudantes e não apenas os professores, em temáticas como: a descriminalização dos adolescentes em cumprimento de medida socioeducativa, seja em regime de Liberdade Assistida, semiliberdade ou privação de liberdade, em consonância 
com o ECA; propagar o entendimento da escola e da sociedade como sendo instituições capazes de atuar na ressocialização e reintegração do adolescente autor de ato infracional; combater todos os tipos de preconceitos aos estudantes adolescentes que estão em cumprimento de alguma medida socioeducativa, assim como a inclusão e reforço de atitudes em e para os direitos humanos e o entendimento de sua situação peculiar de desenvolvimento e como sujeito de direitos; estabelecer, junto aos órgãos do Sistema Socioeducativo modelos conjuntos de circulação de informações, formação e troca de experiências sobre a estrutura e funcionamento de cada instituição - quais sejam, SINASE e ESCOLAS; criar, junto à Secretaria de Estado de Educação do DF, através do Núcleo de Orientação Educacional em parceria com universidades e instituições que ofertam cursos na temática da Socioeducação, canais permanentes de comunicação e informação sobre cursos de curta, média e longa duração, com a exigência de vagas para Orientadores Educacionais; solicitar, junto à Secretaria de Estado de Educação do DF a criação de curso permanente, junto à Escola de Aperfeiçoamento da Educação (EAPE), curso permanente em Socioeducação, mesmo em nível de Especialização ou cursos de curta duração. Por outro lado, os Coordenadores em todos os níveis do Serviço de Orientação Educacional no DF, necessitam, urgentemente, passar por cursos de formação em Socioeducação, excluindo-se, claro, os que já possuem tal formação.

A pesquisa possibilitou também, a percepção da necessidade de formação continuada dos Pedagogos-Orientadores Educacionais que atuam nas unidades escolares do DF, no sentido de ofertar cursos que atendam realmente às demandas desses profissionais para além dos temas comumente ofertados. Ademais, percebe-se em linhas gerais e até em conversas com alguns diretores escolares, que não foram alvo dessa pesquisa, mas com os quais conversamos informalmente nos contatos iniciais para a solicitação de autorização para a construção de informações para a pesquisa, que há pouca ou quase nenhuma formação dos professores nessa temática. Inclui-se aí os diretores, coordenadores pedagógicos, supervisores, os quais fazem parte da carreira Magistério Público da SEEDF, em Socioeducação, o que mostra uma lacuna entre a prática docente e a realidade que se apresenta nas escolas da rede pública de ensino.

Cumpre dizer também, que, nas nossas pesquisas e estudos para fundamentação teórica, percebemos uma carência de literatura com alusão à prática da Orientação Educacional no contexto da rede socioeducativa, fato que pode ser observado também nos livros e artigos específicos da Orientação Educacional que consultamos. No Distrito Federal inclusive, a Orientação Pedagógica do Serviço de Orientação Educacional, documento que norteia o trabalho desse profissional da rede pública de ensino também não se faz referência a esse respeito. Fato que consideramos grave. 
Entendemos que a discussão iniciada nesta dissertação pode despertar novas pesquisas e trabalhos voltados para os temas abordados, especialmente no que respeito à Psicologia do Desenvolvimento e Educação, assim como a atuação do Serviço Orientação Educacional na Socieoeducação no contexto da escola.

Uma das contribuições mais importantes desta pesquisa, sem dúvida, foi colocar os estudantes adolescentes como sujeitos da investigação, que foram ouvidos pela pesquisadora e que trouxeram sua visão de mundo, de sua condição, da importância da educação e da escola em suas vidas. A pesquisa mostrou a importância de se desenvolver uma escuta sensível desses adolescentes que, por meio de sua linguagem própria e expressão lúdica, puderam nos mostrar que educadores adultos aprendem com estudantes adolescentes sua maneira peculiar de viver e construir uma compreensão de sua realidade. Dessa forma, os adolescentes passam de objetos de estudo a sujeitos que, em diálogo com os educadores, podem construir com eles um conhecimento crítico e legítimo sobre sua vida, sua educação e sobre si mesmos. Assim, tanto os estudantes como os educadores se reconhecem mutuamente e se transformam nessa relação.

Por fim, mas não menos importante, quero enfatizar a relevância deste trabalho de pesquisa em nível de Mestrado para o meu desenvolvimento como pesquisadora e estudiosa de questões que surgiram no contexto de minha própria experiência como Pedagoga Orientadora Educacional. Venho trabalhando com o público de estudantes que inclui adolescentes em cumprimento de medida socioeducativa, na modalidade EJA e no Ensino Médio e o contato investigativo com outros profissionais da área colocou-me numa posição crítico-reflexiva muito especial. Tal posição permite que eu assuma um compromisso ético e político em meu cotidiano interventivo e na construção de um conhecimento pensado e vivido num contexto histórico, cultural e social, sempre com um sentido profissional e pessoal.

Esperamos que este trabalho contribua para o campo de estudo da relação entre a Pedagogia, a Psicologia do Desenvolvimento e a Socioeducação e para a formação de novos profissionais nessa área interdisciplinar. 


\section{REFERÊNCIAS BIBLIOGRÁFICAS}

Abramovay, Miriam A. C., Cunha \& P. P. Calaf. (2009). Revelando tramas, descobrindo segredos: violência e convivência nas escolas., Brasília: Rede de Informação Tecnológica Latino-Americana - RITLA, Secretaria de Estado de Educação do Distrito Federal - SEEDF.

Aguiar, M. A. S. (et al). (2006). Diretrizes curriculares do curso de pedagogia no Brasil: disputas de projetos no campo da formação do profissional da educação. Campinas 27(96), 819-842.

Aleixo, K. C. (2012). Ato infracional: ambivalências e contradições no seu controle. Curitiba: Juruá.

Alves, C. B. \& Pedrosa, R. L. S. (2016). A perspectiva histórico-cultural: contribuições para o estudo da identidade. In: Psicologia dos processos de desenvolvimento humano, cultura e educação. Campinas, SP: Editora Alínea.

Aranha, M. L. A. (2006). Filosofia da educação (3a ed.). São Paulo: Moderna.

Bakhtin, M. (1995). Marxismo e Filosofia da Linguagem. São Paulo: HUDITEC.

Barros, C. S. G. (1997). Pontos de Psicologia do desenvolvimento (10. a ed.). São Paulo: Editora Ática.

Bauer, M. W. \& Gaskell, G. (Orgs), Pesquisa qualitativa com texto: imagem e som: um manual prático ( $8^{\mathrm{a}}$ ed.). Petrópolis, RJ: Vozes.

Biaggio, A. M. B. (2015). Psicologia do desenvolvimento (24. a ed.). Petrópolis: Vozes.

Boal, A. (2008). Jogos para atores e não-atores. Rio de Janeiro: Civilização e Brasileira.

Boal, A. (2013). Teatro do Oprimido e outras poéticas políticas: Augusto Boal. São Paulo: Cosac Naify.

Botelho, A. \& Schwarcz, L. M. (Orgs.). (2012). Cidadania, um projeto em construção: minorias, justiça e direitos. (1.. ed.). São Paulo: Claro Enigma.

Branco, A. M. C. U. A., \& Oliveira, M. C. S. L. (Orgs.). (2012). Diversidade e cultura de paz na escola: contribuições da perspectiva sociocultural. Porto Alegre: Mediação.

Brandist, C. (2012). Repensando o círculo de Bakhtin: novas perspectivas na história intelectual. In M. I. Campos \& R. H. Schettini (Orgs.). São Paulo: Contexto.

Brasil, Constituição. (2006). Constituição da República Federativa do Brasil: 1988. (2. ed.). Brasília: Câmara dos Deputados, Coordenação de Publicações.

Brasil. (2006). Sistema Nacional de Atendimento Socioeducativo (SINASE). Secretaria Especial de Direitos Humanos, Brasília, DF: CONANDA.

Brasil. (2010). Serviço de Orientação Educacional: Orientação Pedagógica. Secretaria de Estado de Educação do Distrito Federal. 
Brasil. (2013). Estatuto da Juventude - Lei no 12.852|2013. Brasília: Presidência da República.

Brasília: Secretaria Especial de Direitos Humanos. 2006). Socioeducação: Estrutura e Funcionamento da Comunidade Educativa. Coordenação técnica Antônio Carlos Gomes da Costa.

Campos, D. M. S. (1987). Psicologia da adolescência: normalidade e psicopatologia (11. a ed.). Petrópolis: Vozes.

Carneiro, L. B. (2015). Características e avaliação de programas brasileiros de atendimento educacional ao superdotado (Tese de doutorado não publicada). Universidade de Brasília, Brasília.

Carretero, M., \& León, J. A. (2004). Do pensamento formal à mudança conceitual na adolescência. In: C. Coll., A. Marchesi, \& J. Palácios (Orgs.), Desenvolvimento psicológico e educação (pp. 323-334). Porto Alegre: Artmed.

Carvalho, F. A. (2010). Adolescente em liberdade assistida: algumas histórias. Jundiaí, Paco Editorial.

Chaves, J. C. (2013). Promessa e frustação da juventude. In: adolescência: temores e saberes de uma sociedade de conflito. Goiânia: Cânone Editorial.

CODEPLAN (2013). Perfil e percepção social dos adolescentes em medida socioeducativa no Distrito Federal. Secretaria de Estado da Criança, GDF: CODEPLAN.

Coll, C.; Marchesi, A., \& Palácios, J. (2004). Desenvolvimento psicológico e educação. Porto Alegre: Artmed.

Cool, C. \& Martí, E. (Orgs.). (2004). Aprendizagem e desenvolvimento: a concepção genético-cognitiva da aprendizagem. In: Desenvolvimento psicológico e educação. Porto Alegre: Artmed.

Costa, A. P. M., Ferreira, K. M. M., Ramirez, S., Ponzio, V. \& Paz, V. (2014). Medidas socioeducativas: gestão da execução. Porto Alegre: Marcavisual.

Coutinho, L. G. (2009). Adolescência e errância: destinos do laço social no contemporâneo. Rio de Janeiro: Nau: FAPERJ.

Cotrim, G. (2013). Fundamentos da Filosofia. São Paulo: Saraiva.

Craidy, C. M. Lazzarotto, G. D. R. \& Oliveira, M. M. (Orgs.). (2012). Processos educativos com adolescentes em conflito com a lei. Porto Alegre: Mediação.

Cubero, R. \& Luque, A. (2004). Desenvolvimento, educação e educação escolar: a teoria sociocultural do desenvolvimento e da aprendizagem. In: Psicologia da educação escolar. (2. ${ }^{a}$ ed.). Porto Alegre: Artmed. 
Denzin, N. K. e Lincoln, Y. S. (Orgs.). (2006). Introdução: a disciplina e a prática da pesquisa qualitativa. In: $O$ planejamento da pesquisa qualitativa: teorias e abordagens. (2. ed.) Porto Alegre: Artmed.

DeMause, L. (1974). The Evolution of childhood. In: DeMause, L. (Ed.). The history of childhood. New Work: Harper \& Row.

Dessen, M. A. \& Costa Junior, A. L. (Orgs.). (2005). A ciência o desenvolvimento humano: tendências atuais e perspectivas futuras. Porto Alegre: Artmed.

Dias, S. S. (2014). A quem serve o diagnóstico de deficiência intelectual? - um estudo do desenvolvimento adulto na perspectiva da psicologia dialética. Universidade de Brasília:UnB.

Duarte, N. (2011). Vigotski e o "aprender a aprender": crítica às apropriações neoliberais pós-modernas da teoria Vigotskiana (5ed.). Campinas, SP: Autores Associados.

Fávero, M. H. (2005). Psicologia e conhecimento: subsídios da psicologia do desenvolvimento para a análise de ensinar e aprender. Brasília: Editora Universidade de Brasília.

Ferreira, E. D. S. (2010). Liberdade assistida no Estatuto da Criança a e do Adolescente: aspectos da luta pela implementação de direitos fundamentais. São Paulo: FAPESP; EDUC.

Ferry, L. (2012). A revolução do amor: por uma espiritualidade laica. Rio de Janeiro: Objetiva.

Fiorin, J. L. (2016). Introdução ao pensamento de Bakhtin (2 $2^{\mathrm{a}}$ ed.). São Paulo: Contexto.

Flick, Uwe. (2004). Uma introdução à pesquisa qualitativa. Porto Alegre: Bookman.

Freire. P. (1996). Pedagogia da autonomia: saberes necessários à prática educativa. São Paulo: Paz e Terra.

Freitas, M. T. (2013). Educação, arte e vida em Bakhtin. Belo Horizonte: Autêntica.

Gerhardt, T. E. \& Silveira, D. T. (2009). Métodos de pesquisa. Organizado por coordenado pela Universidade Aberta do Brasil - UAB/UFRGS e pelo Curso de Graduação Tecnológica - Planejamento e Gestão para o Desenvolvimento Rural da SEAD/UFRGS. - Porto Alegre: Editora da UFRGS.

Giacaglia, L. R. A. \& Penteado, W. M. A. (2013). Orientação Educacional na prática: princípios, histórico, legislação, técnicas e instrumentos (6 $6^{\mathrm{a}}$ ed.). São Paulo: Cengage Learning, 2013.

González Rey, Fernando Luis. (2005). Pesquisa qualitativa em psicologia: caminhos e desafios. São Paulo: Pioneira Thomson Learning.

González Rey, Fernando Luis. (2010). Pesquisa qualitativa e subjetividade: os processos de construção da informação. São Paulo: Cengage Learning. 
Grinspun, M. P. S. Z. (2011). A Orientação Educacional: conflito de paradigmas e alternativas para a escola (5ª ed.). São Paulo: Cortez.

Grinspun. M. P. S. (Org.). (2012). A prática dos Orientadores Educacionais (7ª̣ ed). São Paulo: Cortez.

Grinspun. M. P. S. (Org.). (2014). Autonomia e ética na escola: o novo mapa da educação. São Paulo: Cortez.

Guerra, A. M. C., Kind, L, Afonso, L. \& Prado, M. A. M. (Orgs.). (2012). Psicologia social e direitos Humanos. (2. ${ }^{\mathrm{a}}$ ed.). Belo Horizonte: Artesã.

Guimarães, S. \& Silva Júnior, A. F. (2012). Ser jovem no Brasil: trajetórias juvenis no campo e na cidade. São Paulo: Editora Alínea.

Günther, H. (2006). Pesquisa qualitativa versus pesquisa quantitativa: esta é a questão? Psicologia: Teoria e Pesquisa, 22(2), 201-209.

Gutierra, B. C. C. (2003). Adolescência psicanálise e educação: o mestre "possível" de adolescentes. São Paulo: Avercamp.

Lacasa, P. (2004). Ambiente familiar e educação escolar: a interseção de dois cenários educacionais. In: Desenvolvimento psicológico e educação, C. Coll; A. Marchesi, \& J. Palacios ( $2^{\underline{a}}$ ed.). Porto Alegre: Artmed.

Lago, M. P.; Mozzer, G. N. S., \& Santibanez, D. A. (Orgs). (2013). Adolescência: temores e saberes de uma sociedade em conflito. Goiânia: Cânone Editorial.

Libâneo, J. C., J. F. Oliveira \& M. S. Toschi (2011). Educação escolar: políticas, estruturas e organização. (20ª ed.). São Paulo: Cortez.

Lopes de Oliveira, M. C. S. \& Santana, A. C. (2016). Desenvolvimento humano aproximações a uma perspectiva semiótica e dialógica. In: Psicologia dos processos de desenvolvimento humano, cultura e educação. Campinas, SP: Editora Alínea.

Lopes de Oliveira, M. C. S. (2006). Identidade, narrativa e desenvolvimento na adolescência: Uma revisão crítica. Psicologia em Estudo, 11 (2): 27-436.

Lopes de Oliveira, M. C. S. (et al.). (2016). Psicologia dos processos de desenvolvimento humano: cultura e educação. Campinas, SP: Editora Alínea.

Luckesi, C. C. (2011). Filosofia educação. (3ª ed.). São Paulo: Cortez.

Maciel, D. de A. \& Pulino, L. H. C. Z. (2008). Psicologia e Construção do Conhecimento. Brasília: LGE.

Madureira, A. F. A. \& Abreu Branco, A. M. U. (2012). In: Diversidade e cultura de paz na escola: contribuições da perspectiva sociocultural. Branco, A. M. C. U. A., \& Oliveira, M. C. S. L. (Orgs.). Porto Alegre: Mediação. 
Martín, E. \& Mauri, T. (2004). As instituições escolares como fonte de influência educacional. In: Desenvolvimento psicológico e educação. C. Coll.; A. Marchesi, \& J. Palácios, (2 $2^{\mathrm{a}}$ ed.). Porto Alegre: Artmed.

Mendes, A. M. \& Marinho-Araújo, C. M. (2016). Desenvolvimento humano adulto e mediação estética. In: M. C. S. L. Oliveira, (et. al.). Desenvolvimento Humano, cultura e educação. Campinas: Alínea.

Mussen, P. H., Conger, J. J., Kagan, \& J. Huston, A. C. (1988). Desenvolvimento e personalidade da criança ( $2^{-\underline{a}}$ ed.). São Paulo: Harbra.

Myers, G. (2010). Análise da conversação e da fala. In M. W. Bauer \& G. Gaskell, (Orgs). Pesquisa qualitativa com texto: imagem e som: um manual prático (pp. 271-292) . (8ª ed.). Petrópolis, RJ: Vozes.

Oliva, A. (2004). Desenvolvimento da personalidade durante a adolescência. In: Desenvolvimento psicológico e educação. Cool, C., Marchesi, A. \& Palacios, J. (Orgs.). (2. ${ }^{a}$ ed.). Porto Alegre: Artmed.

Oliveira, J. E. (2012). Violência escolar: os gestores as interfaces com as unidades de apoio e as dificuldades de enfrentamento. São Paulo: Biblioteca24horas.

Oliveira, M. C. S. L.; Chagas-Ferreira, J. F.; Mieto, G. S. M., \& Beraldo, R. (Orgs.). (2016). Psicologia dos processos de desenvolvimento humano: cultura e educação. São Paulo: Alínea.

Ozella, S. (Org.). (2003). Adolescências construídas: a visão da psicologia sócio-histórica. São Paulo: Cortez.

Paiva, I. L. C. \& Rodrigues, D. B. (Orgs.). (2014). Justiça Juvenil: teoria e prática no sistema socioeducativo. (2014). Natal, RN: EDUFRN.

Palácios, J. \& Oliva, A. (2004). A Adolescência e seu significado evolutivo. In C. Coll, A. Marchesi, \& J. Palácios (Orgs.). Desenvolvimento psicológico e educação (Vol. 1, $2^{\underline{a}}$ ed.). Porto Alegre: Artmed.

Papalia, D. E.; O. W. \& Feldman, R. D. (2006). Desenvolvimento humano (8 ${ }^{\underline{a}}$ ed.). Porto Alegre: Artmed.

Papalia, D. E.; Olds, S W. (2000). Desenvolvimento humano (7 $7^{\mathrm{a}}$ ed.). Porto Alegre: Artes Médicas Sul.

Pinto, P. S \& Silva, R. A. S. In: Paiva, I. L. C. \& Rodrigues, D. B. (Orgs.). (2014). Justiça Juvenil: teoria e prática no sistema socioeducativo. (2014). Natal, RN: EDUFRN.

Porto, O. (2009). Orientação Educacional: teoria, prática e ação. Rio de Janeiro: Wak Ed.

Ratner, C. (1995). A psicologia sócio-histórica de Vigotski: aplicações contemporâneas. Porto Alegre: Éticas.

Ribeiro, M. L. S. (1982). História da educação brasileira. São Paulo: Cortez e Moraes. 
Rivero, A. R. \& Luna, I. B. (2012). Narrativas históricas e construção de identidades culturais no contexto educativo. In: Diversidade e cultura da paz a escola: contribuições da perspectiva sociocultural. Abreu Branco, A. M. U. \& Lopes de Oliveira, M. C. S. porto Alegre: Mediação.

Rodriguez, S. N., \& Damásio, B. F. (2014). O desenvolvimento da identidade e sentido e vida na adolescência. In: L. F. Habigzang; E. Diziz, \& S. H. Koller (Eds.), Trabalhando com adolescentes: teoria e intervenção psicológica (pp.3-41). Porto Alegre: Artmed.

Schaffer, D. R. (2009). Psicologia do desenvolvimento: infância e adolescência. São Paulo: Cengage Lerning.

Schilling, F. (2000). Um olhar sobre a violência na perspectiva dos direitos humanos. In: Revista IMESC. (Vol. 02). São Paulo: Instituto de Medicina e Criminologia de São Paulo (IMESC).

Schraml, W. J. (1977). Introdução à moderna psicologia do desenvolvimento para educadores. São Paulo: EPU.

Secretaria de Estado de Educação do Distrito Federal. (2010). Orientação Pedagógica: Ensino Especial. Brasília: SEDF/GEE/DF.

Secretaria de Estado de Educação do Distrito Federal. (2015). Regimento Escolar da rede Pública de Ensino do Distrito Federal (6ª ed.). Brasília: SEEDF.

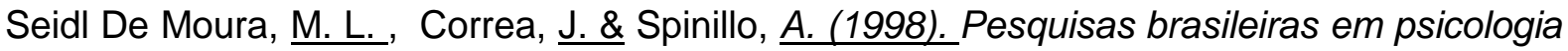
do desenvolvimento. RJ: Eduerj.

Silvestre, E. (2011). Política socioeducativa de direitos e as medidas socioeducativas. Rev. Bras. Adolescência e Conflitualidade 5, 134-159.

Valsiner, Jaan. 2012). Fundamentos de uma psicologia cultural: mundo da mente, mundos da vida. Porto Alegre: Artmed.

Vieira, A. O. M. \& Lopes de Oliveira, M. C. S. (2013). Promoção do desenvolvimento subjetivo do adolescente por meio de intervenção psicopedagógica no contexto socioeducativo. In: Adolescência: temores e saberes de uma sociedade de conflito. Lago, M. P., Mozzer, G. N. S. \& Santibanez, D. A. (Orgs.). Goiânia: Cânone Editorial.

Vigotski, L. S. (1996). Teoria e método em psicologia. São Paulo: Martins Fontes.

Waiselfisz, J. J. (2015). Mortes matadas por arma de fogo - Mapa da Violência. Disponível em: http://www.mapadaviolencia.org.br/pdf2015/mapaViolencia2015.pdf

Yokoy de Souza, T. \& Lopes de Oliveira, M. C. S. (2012). O contexto das medidas socioeducativas: promoção da paz ou valores da cadeia? In M. C. S. Lopes de Oliveira; Branco, A. M. C. U. A. Diversidade e cultura de paz na escola: contribuições da perspectiva sociocultural. Porto Alegre: Mediação. 
Zanella, A. V. (2014). Vigotski: contexto, contribuições à psicologia e o conceito de zona de desenvolvimento proximal. ( $2^{\mathrm{a}}$ ed.). Itajaí: Univali.

Zuin, P. B. \& Reyes, C. R. (2010). O ensino da língua materna: dialogando com Vigotski, Bakhtin e Freire. Aparecida, SP: Ideias \& Letras. 


\section{ANEXOS}




\section{Anexo 1}

\section{ACEITE INSTITUCIONAL}

$\mathrm{O}(\mathrm{A})$ Sr. (a)

diretorla do

está de acordo com a realização da pesquisa O Pedagogo-Orientador Educacional No Acolhimento E Acompanhamento De Adolescentes Em Medida Socioeducativa, de responsabilidade do(a) pesquisador(a) Izete Santos do Nascimento aluno(a) de mestrado no Programa de Pós-Graduação em Processos de Desenvolvimento Humano e Saúde da Universidade de Brasília, realizado sob orientação da prof. ㅁ Dr. a Lúcia Helena Cavasin Zabotto Pulino Orientadora do projeto, após revisão e aprovação pelo Comitê de Ética em Pesquisa do Instituto de Ciências Humanas da Universidade de Brasília - CEP/IH.

O estudo envolve a realização de Fórum de Debate, com Pedagogos-Orientadores Educacionais e oficina com jogos teatrais com estudantes adolescentes. A pesquisa terá a duração de 3 meses, com previsão de início em agostol2016 término em outubro/2017.

$\mathrm{Eu}$, diretor, responsável pelo declaro conhecer e cumprir as Resoluções Éticas Brasileiras, em especial a Resolução CNS no 466/12. Esta instituição está ciente de suas corresponsabilidades como instituição coparticipante do presente projeto de pesquisa, e de seu compromisso no resguardo da segurança e bemestar dos sujeitos de pesquisa nela recrutados, dispondo de infraestrutura necessária para a garantia de tal segurança e bem-estar.

Brasília-DF, de de 


\section{Anexo 2}

\section{ROTEIRO DE CONSTRUÇÃO DE INFORMAÇÕES COM PEDAGOGOS-ORIENTADORES EDUCACIONAIS}

1. O que é ser Pedagogo-Orientador Educacional na Rede Pública de Ensino do Distrito Federal?

2. Qual a sua compreensão sobre a Socioeducação?

3. Que tipo de conhecimento teórico/prático você julga importante para contribuir com seu trabalho junto aos jovens do contexto da Socioeducação?

4. Qual a sua percepção da compreensão que a escola onde atua tem da Socioeducação? Como o Pedagogo-OE e a respectiva instituição de ensino pesquisada compreendem o papel da escola na rede socioeducativa?

5. De que maneira é feito o acolhimento e acompanhamento do estudante adolescente que esteja em cumprimento de medida de LA?

6. Quais as contribuições da instituição de ensino na inclusão de estudantes adolescentes em medida de L.A. 


\section{Anexo 3}

\section{INSTRUMENTO DE CONSTRUÇÃO DE INFORMAÇÕES COM ESTUDANTES}

Nome:

Idade:

Série/Turma:

Data:

Em grupo, escolha uma das 04 palavras abaixo ou mesmo utilize quantas desejar para discutir com seus colegas e logo após apresentar ao grupo geral suas concepções. O grupo pode utilizar para expressar suas ideias: imagens, palavras ou sons. 


\section{Anexo 4}

\section{TERMO DE AUTORIZAÇÃO PARA UTILIZAÇÃO DE IMAGEM E SOM DE VOZ}

\section{PARA FINS DE PESQUISA}

$\mathrm{Eu}$, autorizo a utilização da minha imagem e som de voz, na qualidade de participante/entrevistado (a) no projeto de pesquisa intitulado O Pedagogo-Orientador Educacional No Acolhimento E Acompanhamento De Adolescentes Em Medida Socioeducativa, sob responsabilidade de Izete Santos do Nascimento, vinculado (a) ao/à Universidade de Brasília, no Programa de Pós-Graduação em Processos de Desenvolvimento Humano e Saúde.

Minha imagem e som de voz podem ser utilizadas apenas para análise por parte da equipe de pesquisa (pesquisador e Orientador da pesquisa), atividades educacionais.

Tenho ciência de que não haverá divulgação da minha imagem nem som de voz por qualquer meio de comunicação, sejam elas televisão, rádio ou internet, exceto nas atividades vinculadas ao ensino e a pesquisa explicitadas acima. Tenho ciência também de que a guarda e demais procedimentos de segurança com relação às imagens e sons de voz são de responsabilidade do a) pesquisador (a) responsável.

Deste modo, declaro que autorizo, livre e espontaneamente, o uso para fins de pesquisa, nos termos acima descritos, da minha imagem e som de voz.

Este documento foi elaborado em duas vias, uma ficará com o (a) pesquisador (a) responsável pela pesquisa e a outra com o (a) participante.

Brasília, de 


\title{
Anexo 5
}

\section{TERMO DE RESPONSABILIDADE PELO USO DE INFORMAÇÕES E CÓPIAS DE DOCUMENTOS PARA FINS DE PESQUISA}

\author{
Izete Santos do Nascimento, documento de identificação RG no \\ e do CPF \\ $\mathrm{n}^{\circ}$. \\ domiciliado (a) à (ao)/na(no)
}

DECLARA estar ciente:

a) De que os documentos aos quais solicitou acesso e/ou cópias são custodiados pelo (a) Secretaria de Estado de Educação do DF.

b) Da obrigatoriedade de, por ocasião da divulgação, se autorizada, das referidas reproduções, mencionar sempre que os respectivos documentos em suas versões originais pertencem ao acervo do/da Secretaria de Estado de Educação do DF;

c) De que as cópias dos documentos objetos deste termo não podem ser repassadas a terceiros;

d) Das restrições a que se referem os art. 4 e 6 da Lei n8.159 de 08.01 .1991 (Lei de Arquivos); da Lei o 9610, de 19.02.1998 (Lei de Direitos Autorais); dos art. 138 e 145 do Código Penal, que prevê os crimes de calúnia, injúria e difamação; bem como da proibição, decorrente do art. 5ㅜ, inciso X, da Constituição da República Federativa do Brasil, de 1988, de difundir as informações obtidas que, embora associadas a interesses particulares, digam respeito à honra e à imagem de terceiros;

e) De que a pessoa física ou jurídica, responsável pela utilização dos documentos, terá inteira e exclusiva responsabilidade, no âmbito civil e penal, a qualquer tempo, sobre danos materiais ou morais que possam advir da divulgação das informações contidas nos documentos bem como do uso das cópias fornecidas, eximindo, consequentemente, de qualquer responsabilidade, a Secretaria de Estado de Educação do DF;

DECLARA igualmente que as informações e as cópias fornecidas serão utilizadas exclusivamente por Izete Santos do Nascimento para fins de pesquisa no âmbito do projeto O Pedagogo-Orientador Educacional No Acolhimento E Acompanhamento De Adolescentes 
Em Medida Socioeducativa vinculado ao Programa de Pós-Graduação em Processos de Desenvolvimento e Saúde da Universidade de Brasília.

Brasília, de

Assinatura do (a) pesquisador (a) 